Historic, Archive Document

Do not assume content reflects current scientific knowledge, policies, or practices. 



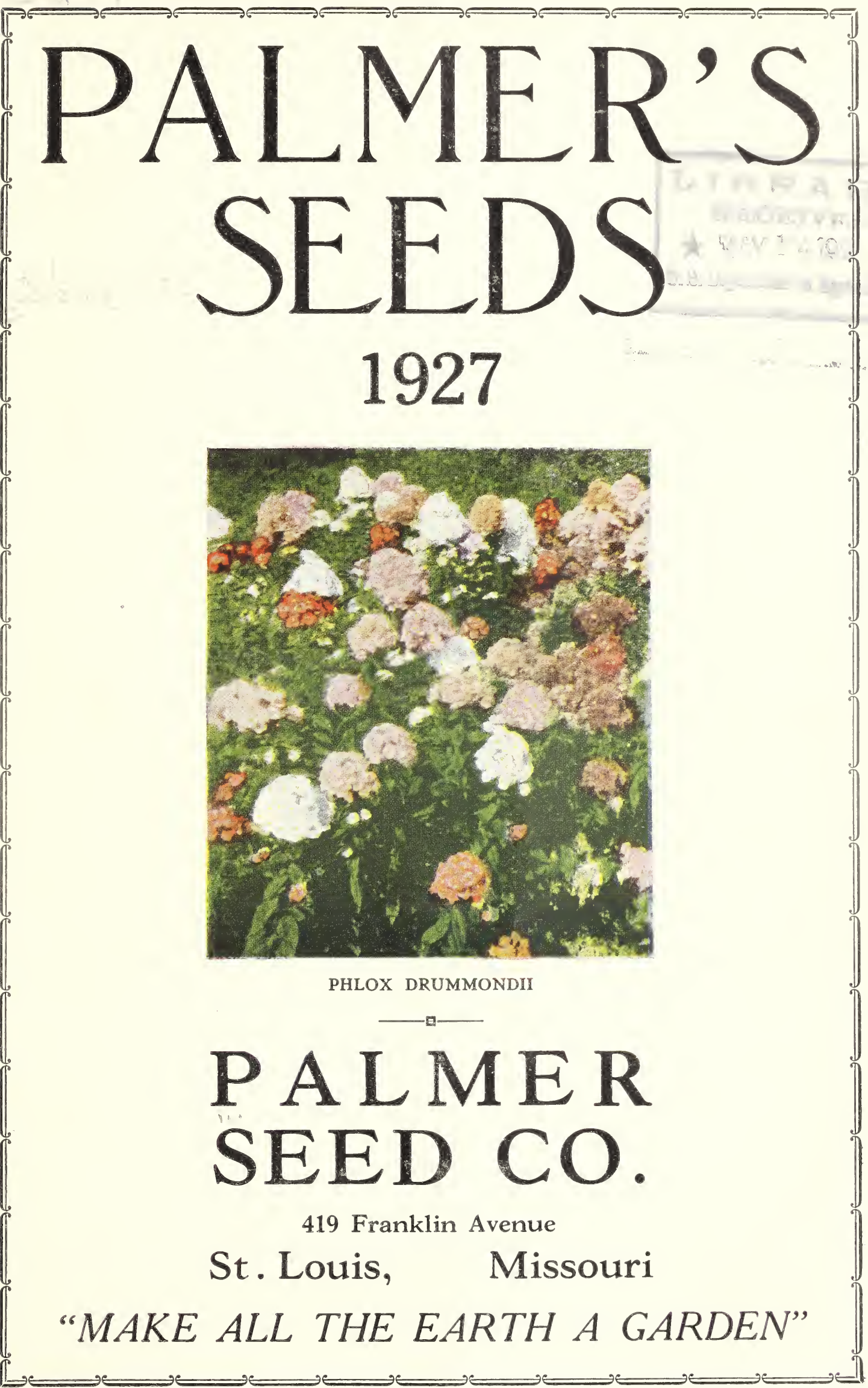




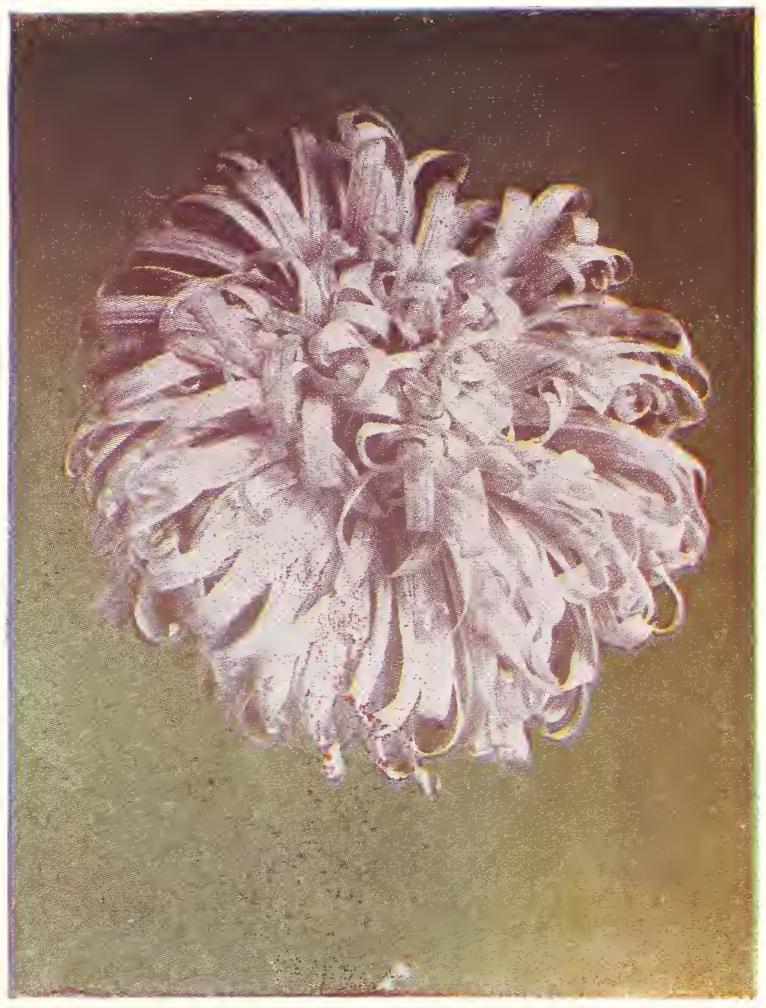

Giant Astermum Aster

\section{Special Inducement!}

We offer a very choice packet of the most beautiful Asters FREE to every customer who orders $\$ 2.00$ worth of seed or more before Mareh 1st. After the first sign of spring weather, seed houses are literally flooded with orders and about $75 \%$ of the business is crowded into the short span of a few weeks. In order to relieve this congestion we will appreciate your taking advantage of this lib. eral inducement.

\section{A 25c Packet of \\ Giant Comet Asters FREE!}

\begin{abstract}
This mannificent strain of American Aster is without a rival. The immense flowers measuring 4 to 6 inches across are borne on long stems from 18 to 24 inches high, having 20 or more blooms on a plant. Has wavy and crested petals resembling chrysanthemums. very beautiful.
\end{abstract}

SEND YOUR ORDER IN NOW

WHILE IT'S FRESH ON YOUR MIND

\section{Palmer's Bargain Collections $\underset{\text { Gor Small }}{ }$}

We have exercised our best judgment in the arrangement of these very special offers, and know you will find them good values. The vegetables are all of popular varieties and the flowers are among the most demanded.

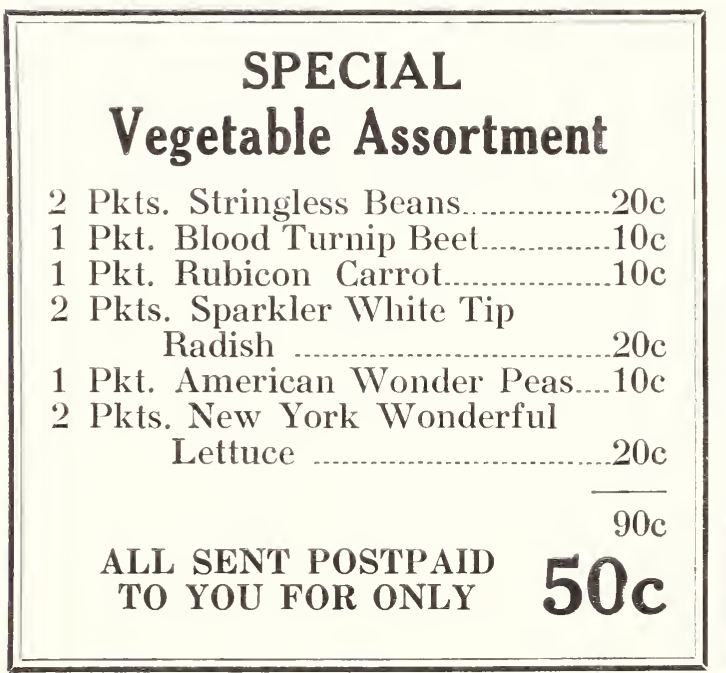

\section{SPECIAL Flower Assortment}

1 l'kt. Giant Asters ….................. 10c

1 Pkt. Heart of France Asters...10c

1 Pkt. Giant Petunia ...................10c

1 Pkt. Spencer Sweet Peas............10c

1 Pkt. Dahlia Flowered Zinnia....10c

1 Pkt. Giant Pansy.....................10c

ALL SENT POSTPAID TO YOU FOR ONLY

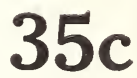

\section{Special Prize for Ten Names}

Send us ten names of the leading families in your neighborhood who plant vegetables and flowers and we will send you a packet of the most beautiful Zimnia--Dahlia Flower Mixed-regular value 20e. In submitting names mention post office and R. F. D. 


\section{A Message to Gardeners Who Consider Quality Seeds The First Requisite to a Good Crop}

$\mathrm{T}^{\mathrm{H}}$ HIS is the first annual catalogue of Palmer's vegetable and flower seeds. Hereafter it will be the chief medium of contact between the House of SUPER-QUALITY SEEDS and the people who plant them. In presenting it to you we desire to cultivate your friendship and your confidence, familiarize you with our company and our Seeds, and bring about a closer relation and better understanding as years go by. Therefore, may we bespeak your thoughtful consideration of this book and the principles that actuate our business policies.

\section{SEEDS ARE BOUGHT ON FAITH}

Perhaps in no other business does the element of trust play such an important part as in the seed business. You take the seedsman's word for the variety of the seed, the type or strain, and its ability to grow-and you cannot test his reliability until the crop is well on its way to maturity. Is it not wise, then, to buy your seeds from a firm composed of seed experts-men whose background of training and experience inspires your confidence?

\section{A STAFF OF SEED EXPERTS TO SERVE YOU}

Every man in the Palmer Seed Company is fitted for his job. Edward C. Palmer spent ten years in the various departments of the Schisler-Corneli Seed Company prior to purchasing the retail department of that firm. The market gardener's department is under the supervision of John W. Eckles, who is known intimately by every grower who comes to St. Louis. Mr. Eckles received his first experience as a boy on his father's truck farm in St. Louis County and later spent twenty years with Schisler-Corneli Seed Company. In choosing a qualified man to look after Flower Seeds and retail business William J. Sherry of Philadelphia was selected. He has an enviable reputation as a seedsman and comes to us with thirty-five years experience in flower seeds, vegetable seeds, bulbs and nursery stock. Mr. Sherry's advice will be valuable to anyone who plants seeds. These men are at your command. Their thorough understanding of the problems of gardening gives them an appreciation of your work and a desire to assist you in every way possible.

\section{WHY PALMER SUPER-QUALITY SEEDS ARE BETTER}

Good seeds are certainly the controlling element in gardening. No matter how fertile your soil, nor how favorable the rain and sunshine, if the seeds are not the best your efforts will be wasted. Our prime purpose will be to sell only select ruality. We will strive constantly to maintain uniformity of varieties and strains and our seeds will be selected from the fields of the world's best seed growers. They will represent the highest perfection in puritv and germination, labeled to comply with your state Pure Seed Law. We want to sell you "Results" and not just seeds. Your success is ours, because if you succeed with our seeds, we succeed with you.

On these clearly defined principles we respectfully solicit your seed business, and know you will be pleased with anything you buy from us.

Cordially yours,

PALMER SEED COMPANY, INC. 


\section{SUGGESTIONS FOR ORDERING}

For quick attention to your order we advise you to make it out according to the following procedure:

CASH WITH ORDER. Please send money with the order sufficient for the whole bill, to facilitate the execution of your order. When only part is remitted goods will be sent to amount of remittance.

WE PAY POSTAGE, EXPRESS OR FREIGHT CHARGES ON ALL ORDERS FOR GARDEN AND FLOWER SEEDS, excepting beans, peas and corn. Field seeds and other items are strictly F. O. B. St. Louis, charges to be paid by purchaser.

REMITTANCE. Remittances should be made by Post Office Money Orders, Bank Drafts, or Express Money Orders. Postage Stamps will be found a convenient method of remitting for small amounts, and can be used by us to advantage.

FORWARDING. We cannot assume any responsibility for delay in transit. When customers fail to receive their packages in a reasonable time, they should inform us, and at the same time send a copy of their order and any other information necessary to trace the goods. In ordering do not fail to give full shipping directions. When such are omitted, we shall use our best judgment and will forward by Express, Railroad or Mail, as may seem to us most advisable.

NAME AND ADDRESS. Please remember to write plainly your Name, Rural Route, Post Office, County and State; also give number and street $01^{\circ}$ P. O. Box as distinctly as possible, to facilitate execution and prevent error; also give name of your nearest Express Office or Railroad Station.

WARRANTY. While we feel that it is to our interest to furnish customers with good seeds, yet we cannot guarantee a crop, as this is dependent upon natural causes, which are beyond our control. But we do guarantee that all seeds sold by us are firstclass, pure and of strong germinating power. However, we give no warranty, express or implied, as to description, quality, productiveness or any other matter of any Seeds, Bulbs or Plants we send out, and we will not be in any way responsible for the crop. If the purchaser does not accept the goods on these terms, they are at once to be returned.

The freshest Seeds may sometimes fail; hence the value of this precaution to send out none but good seeds. We know with proper treatment our Seeds will grow, and by following the cultural directions given the least experienced gardener cannot fail to have success.

\section{Palmer Seed Company, Inc.}

419 Franklin Avenue

ST. LOUIS, MISSOURI

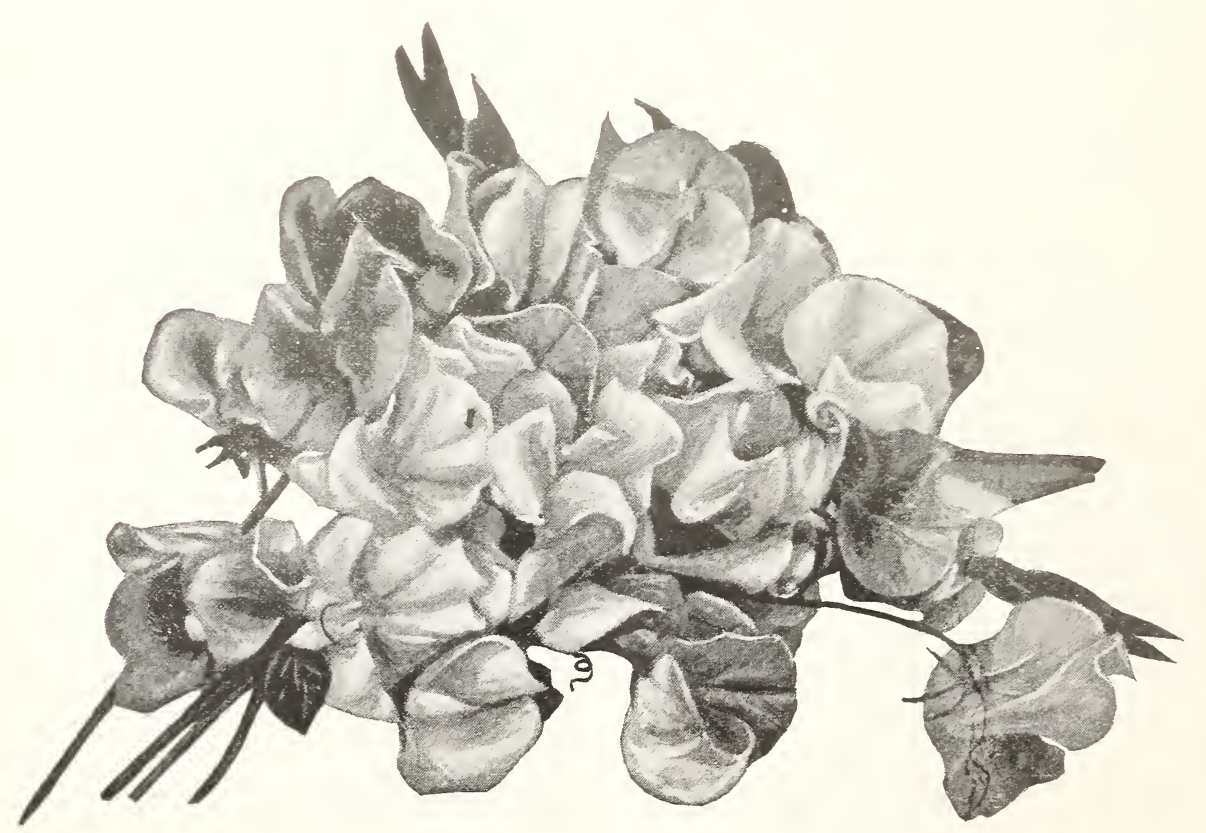

GIANT SPENCER SWEET PEAS

See special offer on Page 32. 


\section{Palmer's Super - Quality Seeds}

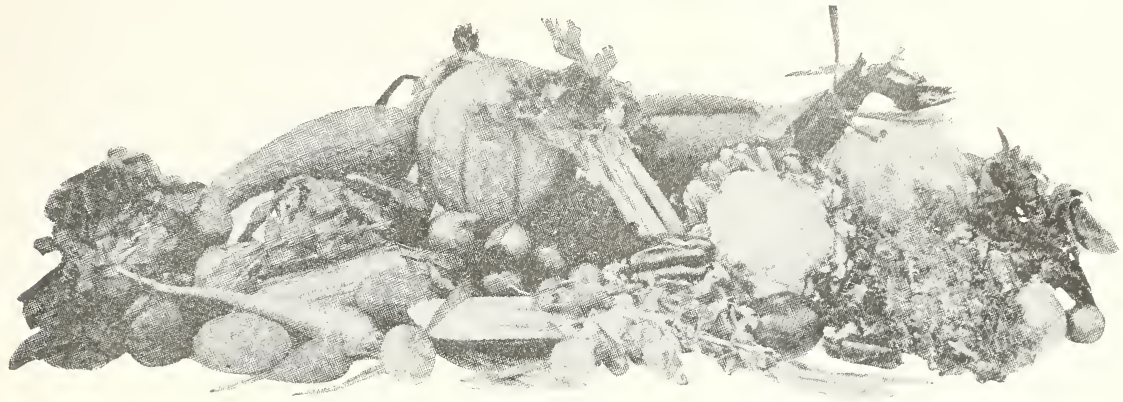

\section{Increased Interest in Gardening}

$\mathrm{T}$

HE steadily increasing demand for better and more beautiful homes has brought with it a new appreciation for gardening. People everywhere are having a finer regard for nature's beauty. They are planting flowers and shrubs to make their home more beautiful, and vegetable gardens are increasing by the thousands.

Plant a garden this year. Whether you desire the beauty of flowers or the tastiness of fresh homegrown vegetables, in raising them you will find wholesome recreation and healthful outdoor exercise. There is a fascination about making things grow that touches the heart of everyone who fully appreciates life.

A small piece of ground will supply a family of average size with fresh vegetables throughout the season. You can do it by selecting more than one variety of each kind; some that mature early and others that mature late, bearing all through the Summer. Even if you have already planned your garden we hope you will find a few things in this catalog that will fit in very nicely.

\section{Vegetable Seeds}

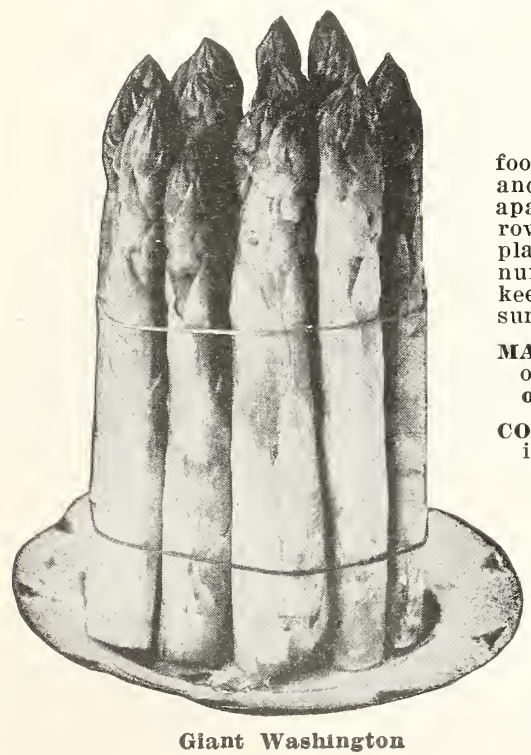

\section{Asparagus}

Sow the seed in drills, about one inch deep, and the rows about one foot apart. Keep the soil mellow and free from weeds during the summer and in the fall or succeeding spring the plants should be set about one foot apart and the crown one foot below the surface. The beds should be narrow so as to permit of cutting to the center. Before winter cover the transplanted beds with about four inches of manure. Salt is an excellent manure for asparagus. Sow a little on the surface in the spring and it will keep down the weeds. The young tops may be cut for the table the second summer, but not very freely until the third.

MARY WASHINGTON-An early giant variety, immune from rust, vigor ous in habit, productive and of rare quality. Parcel Post Paid. Pkt. 10c: oz. $25 \mathrm{c} ; 1 / 41 \mathrm{~b}$. 75e; $11 \mathrm{~b}$. $\$ 2.50$.

CONOVER's COLOSsAL-A well known variety; stalks green; good quality. Pkt. 5c; oz. 15c; $1 / 4$ lb. 30c; 1 b. 75c.

PALMETTO-A heavy producing rust resistant variety, of delicious quality, tender and extremely early. Parcel Post Paid. Pkt. 5c; oz. $15 \mathrm{c} ; 1 / 4$ lb. $30 \mathrm{c} ; 1 \mathrm{~b}$. $75 \mathrm{c}$.

GIANT ARGENTEUIL-An excellent variety of rust resisting qualities, early, productive, and a popular market Asparagus. Parcel Post Paid. Pkt. 5c; oz. 10c; $1 / 4$ 1b. 30c; 1 1b. $75 \mathrm{c}$

\section{Artichoke}

FRENCH GLOHE-The standard and best variety. Parcel Post Paid. Pkt. 10c. 


\section{Bush Beans Green Pod}

MPROVED RED VALENTINE-If you are in doubt about what variety to plant, you will make no mistake in selecting Red ralentine The pods are about 4 inches long, fleshy, erisp, tender. Parcel Post not prepaid. Pkt. 10c; 11/2 1b. 20c; 1b. 35e: 5 lbs. $\$ 1.40$.

LONGFELLOW-Yields round, straight, fleshy pods that average G inches 0 more in length; free of tough lining and until the pods are old are almost entirely stringless. Parcel Post not prepaid. Plit. 10c; $1 / 2$ 1b. 20c; 1b. 35e; 5 lbs. $\$ 1.40$.

STRINGLESS REFUGEE--Fine for later planting, pickling and canning. The round pods are 5 inches long, tender and of splendid quality. Parcel Post not prepaid. Pkt. 10e; 1/2 1b. 20e; 1b. $35 \mathrm{c} ; 5$ 1bs. $\$ 1.40$.

IBLACK VALENTINE-The hardiest of all beans; will stand more frost than any other sort. The pods are long, straight, very handsome; are produced very profusely. Parcel Post not prepaid. Pkt. 10c; 1/2 1b. 20c; 1b. 35e; 5 lbs. \$1.40.

BLRPEE'S STRINGLESS GREEN POD-Early and hardy, pods round, perfectly stringless, tender and brittle, and of the highest quality. Parcel Post not prepaid. Pkt. 10c; 1/2 1b. 20c; 1b. 35c; 5 lbs. $\$ 1.40$.

GIINT STRINGLESS GREEN POD-Exceptionally fine for either home use or market. The pods are round, 5 to 6 inches long, meaty, perfectly stringless, and are borne continuously for weeks. Parcel Post not prepaid. Pkt. 10c; $1 / 2$ 1b. $25 \mathrm{c}$; $1 \mathrm{~b} .40 \mathrm{c}$; 5 1bs. $\$ 1.65$.

BOUNTIFUL-Not quite as early as some kinds, but bears for a long season; the rich, green pods are extra long, broad, thick, meaty, meltingly tender and witl scarcely a trace of string. Parcel Post not prepaid. Pkt. 10c; 1/2 1b. 25c; 1b. 40c; 5 lbs. \$1.65.

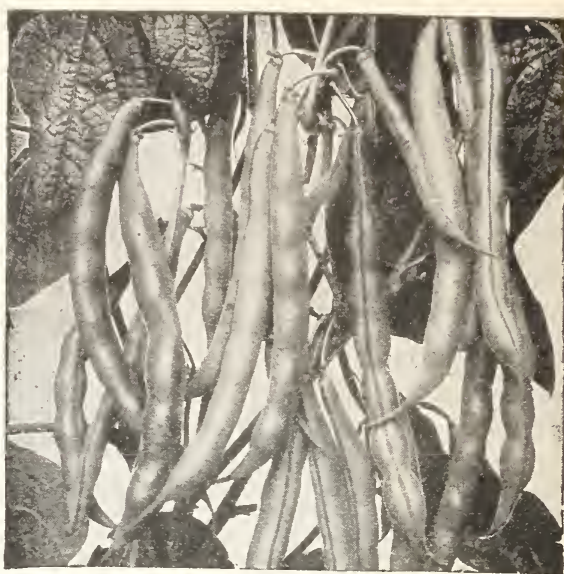

Improved Red Valentine

FILL ME. I URE-One of the best and most satisfactory of the stringless, green-podded snap beans. A very early, productive, high quality variety, with long. straight, fleshy, round pods and entirely without strings; excellent for either market or home garden. Parcel Post not prepaid. Pkt. 10c; 1/2 1b. 25c; $1 \mathrm{~b}$. 40c; 5 1bs. $\$ 1.65$

TENNWSSEE GREEN POD-Yields the longest and largest pods of any Bush Bean, often 6 to 7 inches long, flat and somewhat irregular in shape but of fine flavor. I'arcel Post not prepaid. Pkt. 10e; 1/2 1b. 25e; 1b. 40c; 5 lbs. \$1.65.

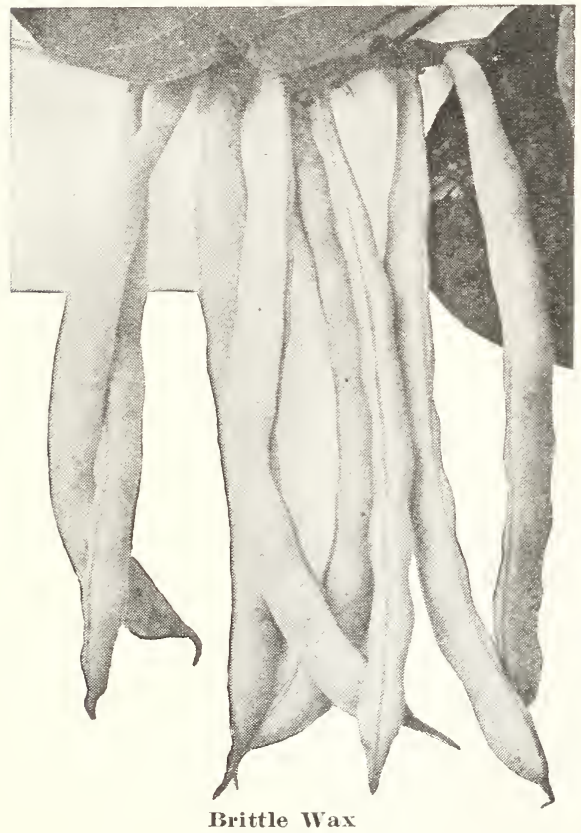

\section{Wax Pod}

BRITTIE W IX-An extra early hardy variety with round pods. entirely stringless. Very prolific and good flavored. Parcel Post not prepaid. Pkt. $10 \mathrm{c}$; $1 / 2$ 1b. $20 \mathrm{c} ; 1 \mathrm{~b} .35 \mathrm{c} ; 5$ lbs. $\$ 1.50$.

DAVIS WIITE-Productive; the pods are long, creamy yellow and free from rust. Parcel Post not prepaid. Pkt. 10c; 1/2 1b. 20c; lb. $35 \mathrm{c} ; 5$ lbs. $\$ 1.40$.

CYRIVALED WAX - A very desirable, extra early, productive va riety with beautiful, showy golden-yellow pods, which show their color at an early stage of growth. The pods are nearly six inches long, almost round, straight or slightly curved, and while showing a trace of string, are brittle and tender. The plant is strong and vigorous and quite free from rust. Parcel Post not prepaid. Pkt. $10 \mathrm{c} ; 1 / 2$ lb. 20c; lb. 35c; 5 1bs. $\$ 1.40$.

SIRE CROP WAX-Bears round, clear, rich, yellow pods in 50 days which are meaty and tender. Parcel Post not prepaid. Pkt. 10c; $1 / 2$ 1b. 20e; $11 b .35 c ; 5$ lbs. $\$ 1.40$.

IMPROVED GOLDEN WAX-Vines medium sized, vigorous and hardy; pods broad, flat and of golden yellow color. This variety is an improvement over the old Golden Wax. The plants are very resistant to rust. Parcel Post not prepaid. Pkt. 10c; 1/2 1b. 20c 1b. $35 \mathrm{c} ; 51 \mathrm{bs} . \$ 1.40$.

PENCIL POD BLACK WAX-Bushy vines, very prolific, 15 inches high, bear round, thick, stringless, rich yellow pods, 6 to 7 inches long, of excellent quality. Parcel Post not prepaid. Pkt. 10c; 1/z 1b. $20 \mathrm{c} ; 1 \mathrm{~b} .35 \mathrm{c} ; 5$ lbs. $\$ 1.40$.

CURRIES RUST PROOF WAX-The best round podded variety. Sure to yield an early and profitable crop. Pkt. 10e; 1/2 1b. 20c; Ib. $35 \mathrm{c} ; 5 \mathrm{lbs}$. $\$ 1.40$.
REFCGEE WAX (Stringless)-A popular mid-season, hardy and desirable variety with numerous round, stringless, bright yellow pods; desirable for canning. Parcel Post not prepaid. Pkt. 10c; 1/2 1b. 25c; 1b. 40c; 5 1bs. $\$ 1.50$.
WARD WELL'S KID NEY WAX-A strong grower; bear heavy crop of broad, waxy yellow pods, brittle and fine Havor. Parcel Post not prepaid. Pkt. 10c; 1/2 lb. $20 \mathrm{e} ; 1 \mathrm{~b}$. 35e; 5 lbs. $\$ 1.40$.

\section{Bush Lima}

HENDERSON'S BUSH LIMA-Beans are small but very productive. Parcel Post not prepaid. Pkt. 10c; 1/2 1b. 20c; 1b. $35 \mathrm{c} ; 5$ lbs. $\$ 1.50$.

FORDHOOK BUSH LIMA-A very large seeded Bush Lima Bean; produces a very large, strong, true bushlike growth. The pods are borne in clusters of from 4 to 8 and measure from 4 to $51 / 2$ inches long about 1 1/4 inches wide. The pods contain from 3 to 5 large beans. Matures in 60 days. Parcel Post not prepaid. Pkt. 10c; 1/2 1b. 30c; 1b. 50c; 5 lbs. $\$ 1.75$.

BURPEE'S IMPROVED BUSH MIMA-A decided improvement on the old sort and by far the best of the large, flat-seeded type. The vine is more sturdy and productive; beans are larger and thicker than in the old form and average one more bean to the pod. Parcel Post not prepaid. Pkt. 10e; 1/2 lb. 20c; lb. 35e; 5 lbs. $\$ 1,50$. 


\section{Pole or Running Beans}

KENTUCKY WONDER, OP OLD HOMESTEAD-It is almost needless to say anything about this great Pole Bean, for who has not grown it? The yield is great, the quality is good, and no bean is more sure of making a crop. It bears in 65 days from plantiug: should be kept picked so that it will continue bearing until frost. The beans are 6 to 12 inches long tender and rich. Parcel Post not prepaid. Pkt. 10e; 1/2 1b. 20e; 1b. $35 \mathrm{e} ; 5$ lbs. $\$ 1.40$.

SPECKLEN CUT-SHORT OR CORN IILL-Used for planting among corn; one of the best. Pods short, cylindrical and ten der. Beans nearly oblong, cut off diagonally at the ends ; white covered at one end and slightly over the surface with reddish-brown dots. Parcel Post not prepaid. Pkt. 10c; 1/2 1b. 20c; lb. 35c; 5 lbs. \$1.40.

DUTCH CASE KNIFE-Pods long, green and flat; can be either snapped or shelled. Immensely productive and excellent flavor. Parcel Post not prepaid. Pkt. 10c; 1/2 1b. 20c; 1b. 35e; 5 lbs. $\$ 1.40$.

WHITE CREASEBACK-Especially valuable on account of its earliness. Parcel Post not prepaid. Pkt. 10c; 1/2 1b. 20c; 1b. $35 \mathrm{c} ; 5$ los. $\$ 1.40$.

S'T. LOUIS WHITE CORN FIELD-One of the earliest and most productive pole beaus, bearing round, fleshy, long pods in large. clusters. Seeds are pure white and can be used as a shell bean. Parcel Post not prepaid. Pkt. 10e; 1/2 1b. 20c; 1b. 35e; 5 lbs. $\$ 1.40$.

LAZY WIFE-Great favorite; pod from four to six inches long, stringless, rich buttery flavor; beans are white and make a fine shell bean; pods remain green and tender long. Parcel Post not prepaid. Pkt. 10c; 1/2 1b. 20c; 1b. 35c; 5 1bs. \$1.40.

HORTICULTIRAL OR SPECIRLED CRANBERRY-Showy, ex cellent eitler as a suap or shell bean. Immense bean of finest quality. Parcel Post not prepaid. Pkt. 10e; 1/2 1b. 20c; 1b. 35e: 5 lbs. $\$ 1.40$.

GOLDEN CLUSTER IVAX--Early, productive; golden wax pods six to eight inches loug. Parcel Post mot prepaid. Pkt. 10e: $1 / 2$ lb. 20c; lb. 35e; 5 lbs, $\$ 1.40$.

L.IRGE WHITE LIMA-Largely grown and highly esteemed. Parcel Post not prepaid. Pkt. 10e; 1/2 $1 \mathrm{~b}$ $20 \mathrm{c} ; 1 \mathrm{~b}$. 35c; 5 lbs. \$1.50.

KING OF THE GARDEN LIMA-Pods are large, numerous and well filled, beans are large and uniform. Productive. Parcel Post not prepaid. Pkt. 10c; 1/2 lb. 20c lb. 35e: 5 libs. \$1.50.

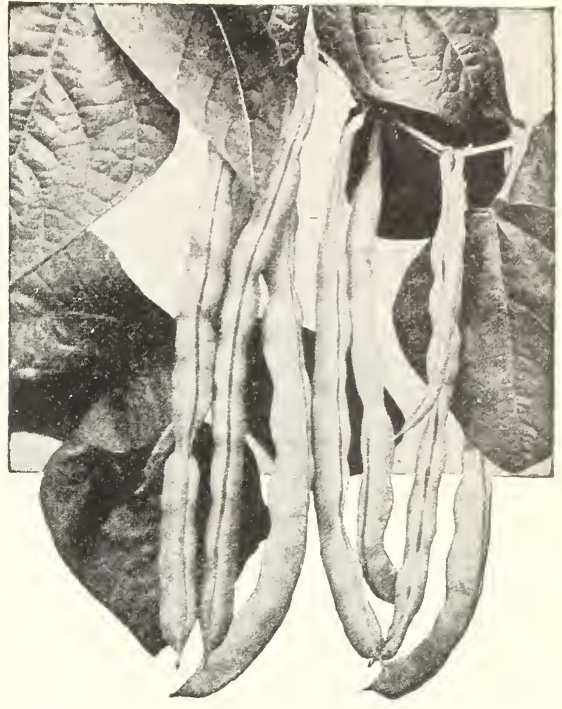

Kentucky Wouder

\section{Brussels Sprouts}

CULTURE-A vegetable cultivated the same as cab bage. The small heads which appear along the upper part of the stalk between the leaves make a fine dish when well prepared. Should be sown during Spring and Fall. Matures in 90 to 120 days. Parcel Post Paid. Pkt. 10e; oz. 25e; 1/4 lb. $\$ 1.00$

\section{Beets}

EARLY ECLIPSE-An early bect especially desirable for the home garden and used for bunching. The tops are small. The roots are bright deep red, smooth, slightly top shaped, with a small tap and small collar. The flesh is bright red, zoned witl pinkish white, very sweet, crisp and tender. Parcel Post Paid. Pkt. 5c; oz. 10c: $1 / 4$ lb. 30c; 1 b. $90 \mathrm{c}$

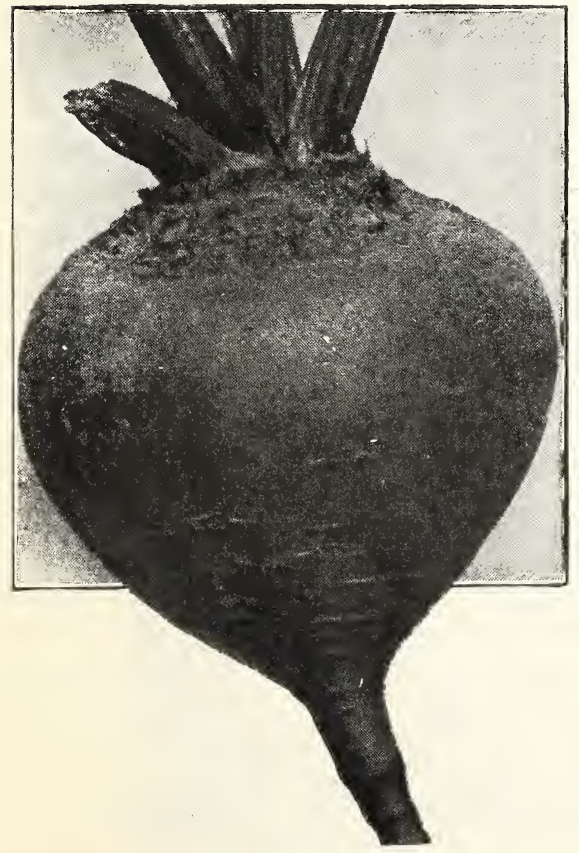

Crosby's Fygptian Beets NITTIN(') GEM-A rapid grower, for forcing and early out$1 / 4$ 1b. $30 \mathrm{c}$; $1 \mathrm{~b}$. 90c.

H1.F LONG BLOOD-Fine dark strain; distinct variety; sinooth and handsome. Parcel Post Paid. Pkt. 5e; oz. 10e; 1/4 $1 \mathrm{~b}$. $30 \mathrm{c} ; 1 \mathrm{~b} .90 \mathrm{c}$.

DETROIT DARI IRED-Here is a beet you will like, whether you wrow fol home use or market. Almost globe shaped with small tops and reoth and of dark blood-red color tops ant lap lant without light rity ing. The quality is fine; fol canning it has no

PRI Please YRL BLOOD TURNIP-It is distinctly a beet that niscriminating gou. A beet that has the roots are medium sized, round, of cark red color and fine flavor. Matures in about t5 days. Parcel Post Paid. Pkt. 5c; oz. 10c: 1/4 1b. 30c; 1b. 90c.

Parcel Post Paid. Pkt. 5c; oz. 100; CRIMSON GLOBE-This is a splentid bronze color, Flesh is rich 10 inches around, globe shape, bronze color. Flesh is rich blood red, sweet, tender and never

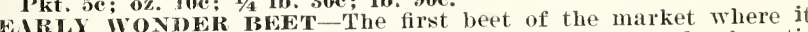
will eort perfect in shape and a beauti ful Superior to Crosby's Egyptian and one week fil red the result of years of selection a rliel. Early wonder Beet is the result of and the improving resulting we believe in the earliest and most handsome globe-shaped beet on the

HDI ND', EARIY BLOOD TURNIP-One of the most uniform of all turnip beets. with very small tops of bronze red, good morlens good for home gardens. Parce Post Paid Pkt. 5e; oz. 10c; 1/4 lb. 30c; lb. 90e.

crost CROSBY's IMPRoNED EGT Egyptian as the combination of eartiness, good shape, good color and good quality. It is not as flat as Extra carly Egyptian nor as round as Eclipse these varieties are its rivals in earli ness. The color is bright red with bright vermilion-red flesh, very sweet and tender. It has the advantage of being fit for use earlier than nost beets, as it takes on its turnip shape at a to tops and tap root are both smail Parcel Post Paid. Pkt. 5c; oz. 10c; 1/4 lb. 30c; 1b. 90c. MPROYED LONG sMOOTH BLOOD-Flesh tender and sweet. Parcel Post Paid. Pkt. 5c; oz. 10c; 1/4 1b. 30c; 1b. 90c. 


\section{Palmer's Sugar Beets}

GIANT HALF SUGAR ROSE (Feeding Sugar)-A most valuable, large yielding variety for feeding, roots oval-shaped: skin rose colored, flesh white. Has a larger sugar content and feeding value than most beets of its class. Parcel Post Paid. Pkt. 5c; oz. 10c ; $1 / 4$ 1b. 20c; 1b. 50c.

VILMORIN IMPROVED WHITE SUGAR-A much Improved strain, very valuable as a sugar-producing beet. Parcel Post Paid. Pkt. 5c; oz. 10c; 1/4 1b. 20c: 1b. 50c.

KLEIN WANZLEBEN-Larger than Vilmorin; good sugar beet; very hardy. Parcel Post Paid. Pkt. 5c; 10. 10c: $1 / 41$. 20c; $1 b$. 50c.

\section{Palmer's Mangel Wurzels}

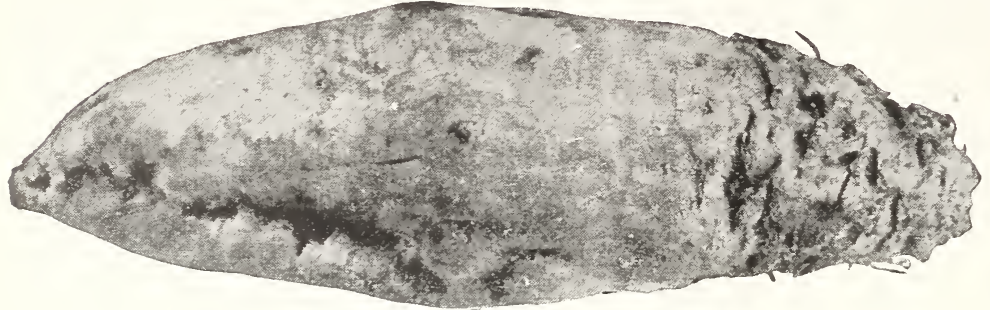

Improved Mammoth Long Red

Cse for Feeding Cattle-Sow Five Lbs. Per Acre

GOLDEN TANKARD MANGELSmall top, smooth, rich skin, broad shoulders, very solid fleshed, golden stemmed, heavy producer. Parcel Post Paid. Pkt. $5 \mathrm{c} ; 0 z .10 \mathrm{c} ; 1 / 4$ 1b. 20c; 1b. 50c.

IMPROVED MAMMOTH LONG RED-The well-known large, long variety; grows well out of ground. Color light red. Very productive. Pkt. 5e; oz. 10c 2 oz. 15c; 1/4 1b. 20c; 1b. 50c. Parcel Post Paid. ORANGE GLOBE MANGEL-WURZEL-Of distinct RED GLOBE MANGEL-WLRZEL-Similar to the Yelshape; one of the most productive, hardy, vigorous. Parcel Post Paid. Pkt. 5c; oz. 10c; 1/4 1b. 20c; 1b. 50. low Globe; productive. Parcel Post Paid. Pkt. 5e oz. $10 \mathrm{c} ; 1 / 4 \mathrm{lb} .20 \mathrm{c} ; 1 \mathrm{~b} .50 \mathrm{c}$.

\section{Cabbage}

DENMARK AND LONG ISLANI STOCKS

EARLY JERSEY WAKEFIELD-Long recognized as the earliest marketable cabbage. In size, medium; in shape, pyramidal with pointed peak. Its uncommonly fine heading qualities, together with its fitness for wintering in cold frames, pleases the most critical gardeners. Our strain of seed is of superior quality. Pkt. 10c; oz. 25e; 2 oz. 45c; 1/4 1b. 75c; 1 1b. \$3.00. Parcel Post Paid.

NEW GOLDEN ACRE-A wonderfully fine extra early, roundheaded variety on the order of Copenhagen Market. The plant is small, very compact, with few outer leaves and matures somewhat earlier than Jersey Wakefield. Parcel Post Paid. Pkt. 15c; 0z. 75c; 1/4 1b. \$2.00; 1b. \$7.50.

COPENHAGEN MARKET-The earliest large round-headed cab bage offered today. It is as early as Early Jersey Wakefield, heads perfectly round and very solid. It is very compact in habit, and can be planted as close as Wakefield. The heads all mature at one time, and will stand a long time before bursting. Heads average about eight pounds each. Pkt. 10c; oz. 35c; 1/4 1b. $\$ 1.00 ; 1 b$. \$3.50. Parcel Post Paid.

LARGE CHARLESTON WAKEFIELD-Similar in many respects to the Jersey Wakefield, except it is one week later and much larger, equally as solid and less pointed. Maturing as it does in about 95 days, it makes an ideal variety to follow the Jersey Wakefield either for market or home use. Of exceeding hardi ness. Vigorous grower, slightly spreading leaves. Heads hard and solid. Mild, pleasing flavor. Crisp and tender. Good keeper and shipper. Pkt. 10c; oz. 25c; $20 \% .45 \mathrm{c} ; 1 / 4$ ib. $75 \mathrm{c} ; 11 \mathrm{lb}$ \$2.50. Parcel Post Paid.

EARLY DWARF FLAT DUTCH-It is a large cropper and a dependable header. A short stemmed variety. Bar a dies days. Grows compact and upright. Leaves few and days. Grows compact and upright. Leaves few and
short. Flat round, solid heads, which are very large for size of plant. Parcel Post Paid. Pkt. 10c; oz. 30c; $1 / 4$ 1b. $\$ 1.00 ; 1 b . \$ 3.00$.

GLORY OF ENKHUIZEN-A medium early, shortstemmed, round-headed variety on the order of Copenhagen Market but later in maturing; can be highly recommended for market gardeners use. Pkt. 10c; oz recommended for market gardeners use. Pkt.

HENDERSON'S EARLY SUMMER-A superior second early sort, produces large and solid heads of fine quality. Parcel Post Paid. Pkt. 10c; oz. 25e; 1/4 $1 \mathrm{~b}$ $75 c ; 1 b . \$ 2.50$.

WISCONSIN HOLLANBER NO. 8 (Yellows Resistant)A heavy yielding late storage type, selected from Danish Ballhead or Hollander. Highly resistant to yellows; round head type; similar in color to $\mathrm{Hol}$ lander. Plit. 15e; 1/2 oz. 40e; oz. 60e; 1/4 1b. $\$ 1.75$ 1b. $\$ 6.00$.

MAMMOTH RED ROCK-By far the best, largest and hardiest heading red cabbage in cultivation; very uniform in size, weight, solidity and deep red color. The heads grow to weigh 10 or 12 pounds. Pkt, 10c; oz. toc; 1/4 1b. 75e; 1b. \$2.50. Parcel Post Paid.

MARBLEHEAD MAMMOTH DRUMHEAD-The largest Cabbage known, weighing in some instances over fifty pounds; under good cultivation acres have been grown where the heads would average thirty pounds each. Parcel Post Paid. Pkt. 10c; oz. 25e; 1/4 lb. 75c; lb. \$2.50.

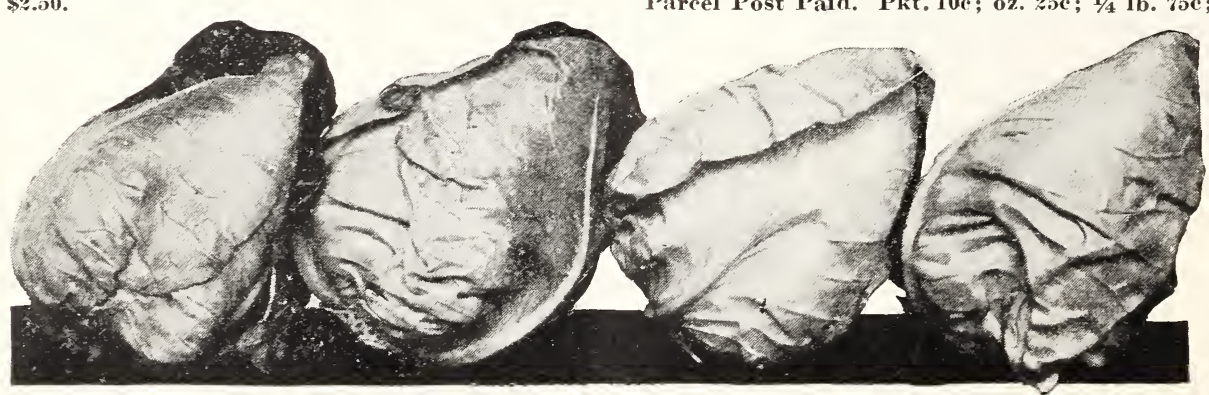


PREMIUM LATE FLAT DUTCH-Sure header, producing large, round, solid heads, flat on the top, of low growing habit, and few outer leaves. Parcel Post Paid. Pkt. 10c; oz. 25c; 1/4 lb. 75c; $1 \mathrm{~b}$. $\$ 2.50$.

EARLY DWARF ULM SAVOY-The heads are firm. solid, beautifully crimpled, and of fine quality. Parcel Post Paid. Pkt. $10 c ; 0 z .30 c ; 1 / 4$ 1b. $85 c ; 1 b . \$ 3.00$.

IARGE DRUMHEAD SAVOY-The best and largest heading of the Savoy Cabbage. Few people seem to know the delicious flavor of Savoy Cabbage. It is far superior to the flat-leaved sorts, and as tender as cauliflower after frosts. Parcel Post Paid. Pkt. 10c; oz. 40c; $1 / 41$. $\$ 1.40$.

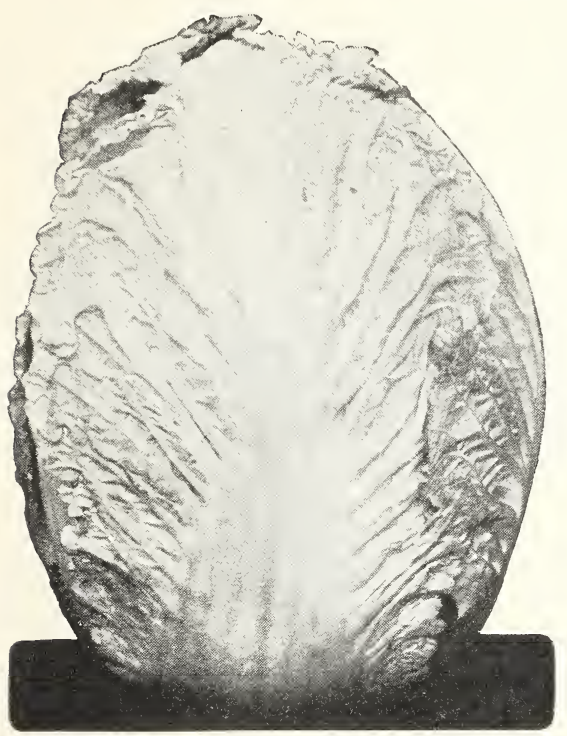

Chinese or Celery Cabbage

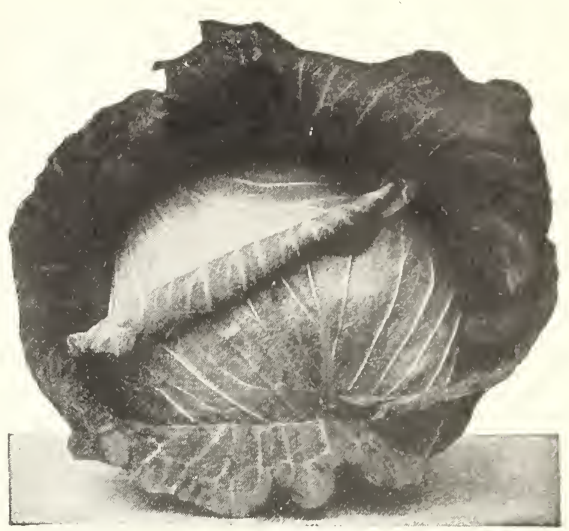

Premium Iate Flat Dutch

CHINESE or CHLERY CABBAGE-Pe-Tsai-Has a mild cabbage flavor, very delicate and very fine salad. When cooked it makes greens delicately cabbage-flavored and not at all like boiled cabbage. It blanches to almost clear white.

The culture is the same as for Cabbage. The seed should be sown for fall crop in June, July to September, half inch deep in the row and rows about 24 inches apart. When the plant has grown up to 5 or 6 inches in height, thin to 10 inches apart. Parcel Post Paid. Pkt. 10c; oz. $30 \mathrm{c} ; 1 / 4$ 1b. $85 \mathrm{c} ; 1$ b. $\$ 3.00$.

PACMER'S EARLY MARKET-A round headed variety of European orimin, ready to market as early as Early Jersey Wakefield. Produces compact solid heads weighing 5 to 8 pounds with few outer leaves. Parcel Post Paid. Pkt. 10c; oz. 40c: $1 / 4$ 1b. $\$ 1.50 ; 1 b$. $\$ 5.00$.

ALL SEASONS-A splendid main crop sort. Remarkable for its ability to stand hot sun and dry weather. Makes solid hard heads, of large size. Parcel Post Paid. Pkt. 10c; oz. 30c; 1/4 lb. 85c: 1 b. $\$ 3.00$.

GENUINE SURE-HEAD-Never fails to make a large, fine head, with few outer leaves; fine grower; flat Drumhead.... Parcel Post Paid. Pkt. 10c; oz. $30 \mathrm{c} ; 1 / 4$ 1b. $85 \mathrm{c} ; 1 \mathrm{lb} . \$ 3.00$.

\section{Garden Carrots}

RUBICON-Half loug, stump rooted. Large, thick and dark orange color. Parcel Post Paid. Pkt. 5c; oz. 15c; 1/4 1b. 35c ; Ib. $\$ 1.00$.

EARLY HALF-LONG SCARLET (stump rooted)-Bright scarlet color, becoming yellow in center. Parcel Post Paid. Pkt. 5c oz. $15 \mathrm{c} ; 1 / 4$ lb. $35 \mathrm{c} ; 1 \mathrm{~b} . \$ 1.00$.

EARLY SHORT HORN-Stump rooted; bright orange color Parcel Post Paid. Pkt. 5e; oz. 15c; 1/4 1b. 35c; 1b. 90c.

DANVERS-Half long, stump rooted; bright orange color. Parcel Post Paid. Pkt. 5c; oz. 15c; 1/4 1b. 35c; 1b. \$1.00.

LARGE YELLOW BELGIAN-Very large; excellent stock Carrot. Parcel Post Paid. Pkt. 5c; oz. 10c; 1/4 1b. 25e; 1b. 75c.

OXHEART OR HALF-LONG GUERANDE-This is one of the most valuable of recent introduction, either for family or market; most beautiful shape and rich orange color. Parcel Post Paid. Pkt. 5c; oz. 15e; 1/4 1b. 35c; 1b. \$1.00.

CHANTENAY-Deep orange flesh; fine grained; stump rooted. Parcel Post Paid. Pkt. 5c; oz. 15e; 1/4 1b. 35c; 1b. $\$ 1.00$.

LONG ORANGE-Large size for garden and field culture. Parcel Post Paid. Pkt. 5c; oz. 15c; 1/4 1b. 35c; 1b. 90c.

INTERMEDIATE-From 10 to 12 inches in length and 2 to 3 in., in diameter at top, tapering gradually. Parcel Post Paid. Pkt. 5e; oz. 15e; $1 / 4$ lb. 35e; 1b. $\$ 1.00$.

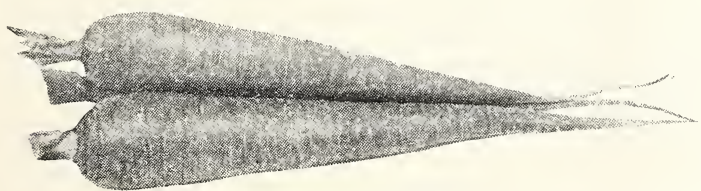

Long Orange

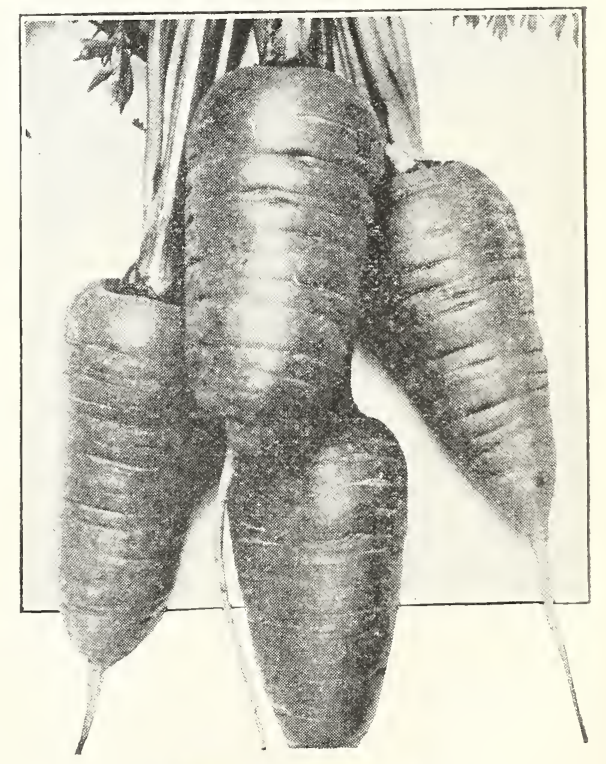

Rubicon Ialf Long Carrots 


\section{Cauliflower}

CULTURE-This is the same as for Cabbage, except that extra manure and plenty of water will pay upos this. If the soil be dry, water frequently, and if the plants could have a heary mulch of hay or straw, it would keep the soil moist and the plants would not suffer from drouth. The early kinds should be strong. from dre middle of enough to plant out not later than the middle of as for Cabbage. To destroy the Cauliflower maggot, it is recommended to take one ounce of sulphate of potassium and dissolve it in one gallon of water. Heat the liquid to about 100 degrees, take a large spoon, or something that will hold the 100th part of a gallon, and pour the liquid against the stalk of the plant just above the ground.

EXTRA EARLY DWARE ERFURT-Short stem ; very fine. A very popular variety. Parcel Post Paid. Pkt. 15e; 1/2 oz. $\$ 2.00 ; 1 \mathrm{oz} . \$ 4.00$.

EARLY SNOWBALL-A favorite with market gardeners. It is exceedingly early and hardy, aud makes a solid, compact head. Parcel Post Paid. Pkt. 15c: 1/4 oz. 75e; oz. \$2.50.

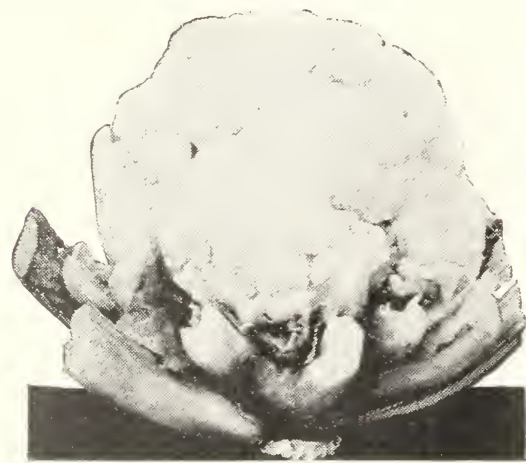

Extra Early Dwarf Eufurt

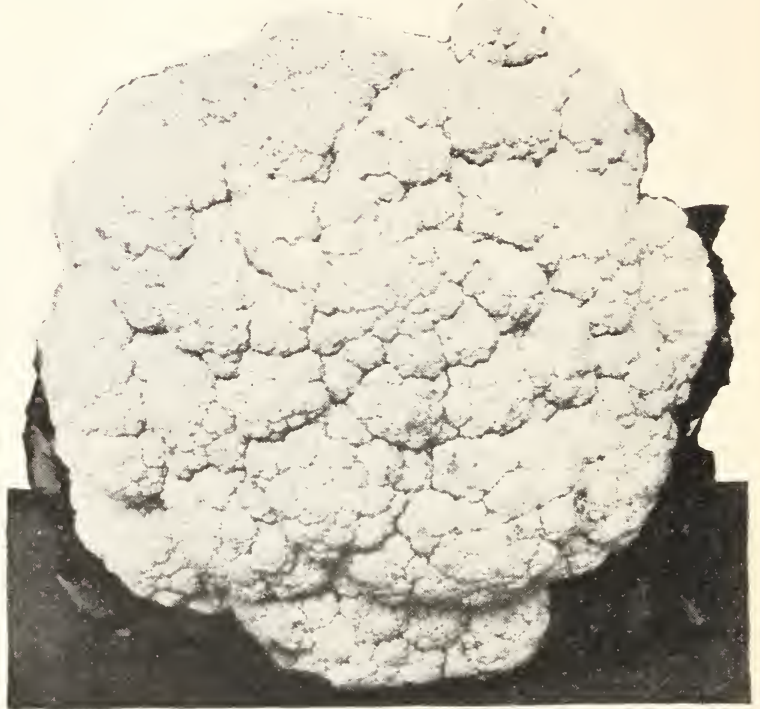

Danish Snowbell

I) INISI EARLY SNOWBALL-Without doubt the best of Cauliflowers; onr seed is of the very finest strain; grown specially for us in Denmark, and sure to make a fine solid head; don't buy cheap Cauliflower seed; there is no seed in which quality counts so much. Parcel Pont Paid. Pkt. 20e; 1/4 oz. \$1.00; 1 oz. \$3.50

\section{Chervil}

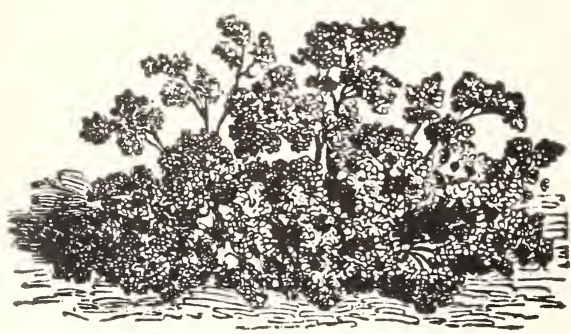

Chervil

CLITLRE-Cultivate and use the curled variety of Chervil like Parsley. Sow at any time in the spring, in shallow drills, one foot apart, in well prepared ground. The leaves of this are used for flavoring and garnising the same as Parsley. Parcel Post Paid. Pkt. 5c: az. $35 \mathrm{c} ; 1 / 4$ lb. $\$ 1.00$.

\section{Chicory}

One ounce will sow 100-foot row WITLOOF-Sow in May, in i2-inch drills; thin to 3 inches apart in rows. During their growth they should be banked up like celery. Use the leaves as a salad. The roots are excellent when boiled. Parcel Post Paid. Pkt. 5e; 0z. 25e; 1/4 1b. 75c; 1b. \$2.00.

\section{Collards}

CULTLRE-Sow seed as for Cabbage in June, July and August for succession; transplant when one month old in rows a foot apart each way and hoe often.

GEORGIA GROWN or soctherN-Parcel Post Paid. Pkt. 5̃c; oz. 10e; 1/4 1b. 3re; 1 b. \$1.00.

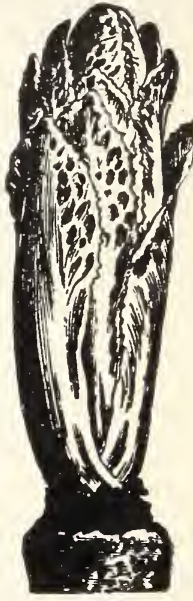

Chicory

\section{Corn Salad, or Fetticus}

CCLTLRE-Sow during August or early in septem ber, in drills a cuarter of an inch deep and six inches apart. If the weather is dry when the seed is sown, tread it in slightly to insure germination. Keep down weeds with hoe. Just before winter cover thinly with straw or leaves.
LARGE SEEDED The hest rariety for family use makes delicious salad: used during the winter as sub stitute for lettuce. Parcel Post Paid. Pkt. 10c; oz. 15e; $1 / 4$ 1b. 30e; 1 lb. $\$ 1.00$.

See the Special Bargain Offers on inside of Front Cover Page. 


\section{Celery}

CULTURE-Sow the seed in a light, rich dry border as early as the ground ean be worked, in drills eight or ten inches apart, and cover the seeds about a quarter of an inch deep, rolling or and con out of the treading them in if the ground be dry. When faily ont of the seed leaf they may be transplanted to another bed, or they may
be thinned out in beds or trenches. The beds should be kept well weeded, and an occasional soaking with water in dry weather will do the plants good. Early in July at the north, a month or six weeks later in the southern states, is the proper time to set the plants out in beds or trenches. Press the soil firmly against the roots. In the garden the better way is to set the plants in shallow trenches-we say shallow, for it is obviously a bad plan to remove all the good soil (as must be done in a deep trench) and put the plants in that which is poor. The plants may be set in a single row in a narrow trench, or the trench may be made into a bed wide enough to hold two, three or four rows, and in that case the plants are in a compact form, to be covered for the winter where they grow.

IMPROVED WHITE PLUME-Naturally white or light foliage requires but little banking up to blanch; very early and extensively grown for market. Parcel Post Paid. Pkt. 10e; oz. 25e; $1 / 4$ lb. ร5e.

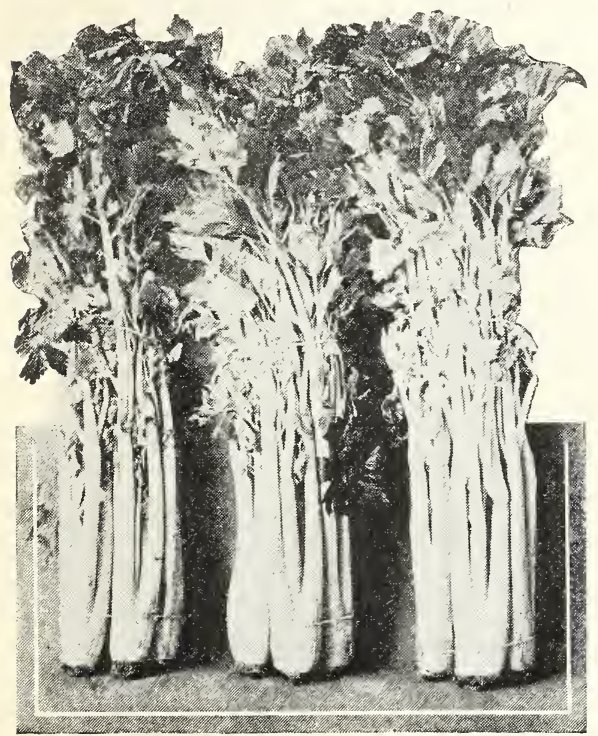

GOLDEN SELFBLANCHING. A grand solid variety, on the style of $t \mathrm{~h} \mathrm{e}$ White Plu $\mathrm{me}$ except that it is golden y e l low where the Plume is white. French grown seed. Parcel Post Paid. Pkt. 10e; oz 50e: 1/4 Ib. $\$ 1.75$.

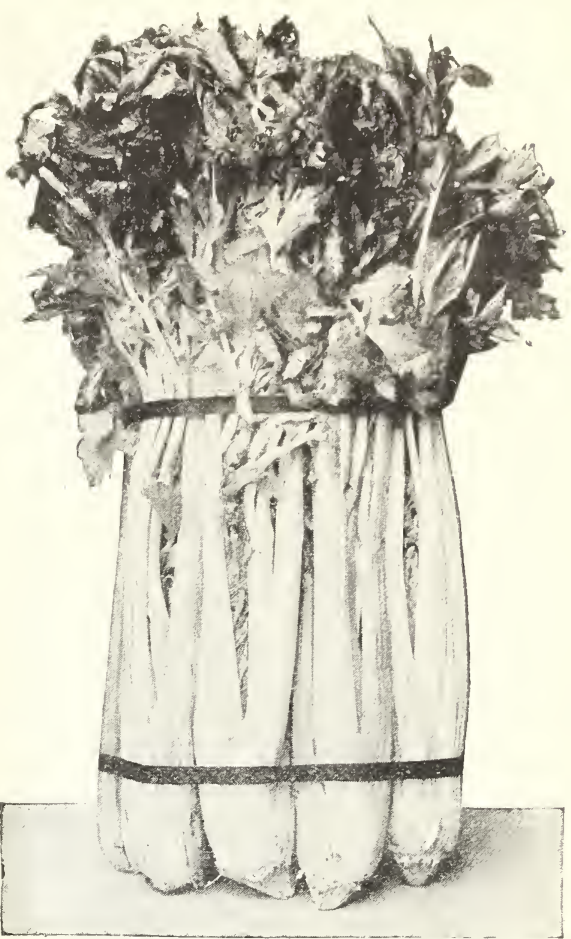

Sanford's Easy Blanching
GINT PASCAI-An easily blanched and fine keeping large sort, of excellent flavor; superior for late use. Parcel Post Paid. Pkt. 10e; oz. 25e; 1/4 lb. 85e.

SANFORD's EASY BLANCHING-Plants are strong and stocky. rreen foliage, slight tinge of yellow in the inner leaves; large and heavy stalks; crisp, tender, handsome appearance, of exand heavy stalks; crisp, tender, handsome appearance, of ex-
cellent nut-like flavor. Blanches quickly and easily when boarded up. Grows immense stalks. Keeps well in trench. Parcel Post Paid. Plkt. 10e; oz. 60e; 1/4 1b. \$2.00.

CELERY SEED

FOR FLAVORING - Used in soups and to make celery salt. Parcel Post Paid. Oz. 10e; $1 / 41$.

Giant Paseal 25e; 1 1b. 75e.

\section{Celeriac}

CELERIAC OR LARGE SMOOTH PRAGUE-An improved form of the rooted celery, roots smooth and round. Parcel Post Paid. Pkt. 5e; oz. 25e; 1/4 1b. 75e.

\section{Cress}

CULTURE-Sow thickly in shallow drills every two or three weeks. It is useful not only for salad, but for the breakfast table and for garnishing. Water Cress should be sown in damp soil, or if a stream of water cau be utilized it would be much finer. It will also thrive in dany hot-beds. Rightly managed its culture is very profitable. To obtain early salad, it is a good plan to sow with the Water Cress seed a strip four inches wide on the outer margin of a hot-bed, inside the frame (where it is always cool). This will be found a satisfactory method of obtaining it early.

CURLED OR PEPPER GRAsi-Parcel Post Paid. Pkt. 10e; o 15e; $1 / 4$ lb. 35̌c.

UPLAND WATER CRess-Parcel Post Paid. Pkt. 10e; oz. 35e; $1 / 4$ lb. $\$ 1.25$.

TRUE WATER CRESS-Parcel Post Paid. Pkt. 10e; oz. 3ãc; $1 / 4$ lb. $\$ 1.25$.

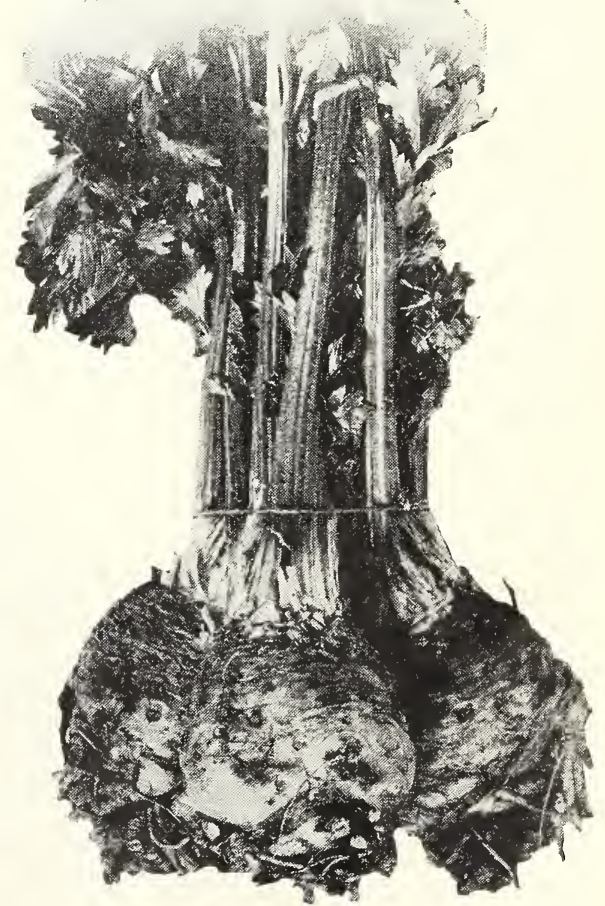

Celeriae 


\section{Cucumbers}

ARLINGTON WHITE SPINE-A selection from the White Spine, being more pointed at each end; the young fruits are usually crisp and tender and are of very dark green color, so that the variety is considered by some to be the best for small pickles. Parcel Post Paid. Pkt. 5c; oz. 10c; 1/4 lb. $35 \mathrm{c} ; 1$ lb. $\$ 1.00$.

Boston PICKLING-A favorite eastern sort of fine quality. Parcel Post Paid. Pkt. 5c; oz. 15e; 1/4 1b. 35c; 1 lb. 90c.

CHiCAgo PICILING-Very popular in Chicago market. Col or deep green, medium size, prominent spines. Parcel Post Paid. Pkt. 5e; oz. 15e; 1/4 1b. 35e; 1 lb. 90c.

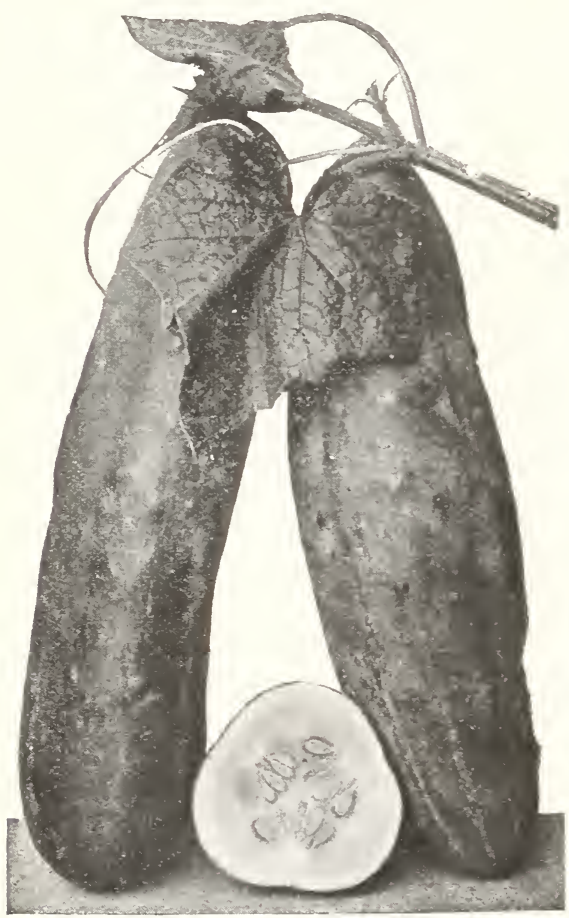

The Davis Perfect Cucumber

THE DAVIS PERFECT CUCUMBER-An eX cellent cucumber for both outdoor use and forcing. It is a carefully selected strain of the extra long White Spine type made by a veteran outdoor and greenhouse grower. of cucumbers. Its raluable points are length, slimness and its dark green color. It is a very vigorous sort and resists blight longer thain most long sorts. Parcel Post Paid. Pkt. 5c; oz. 15e; 1/4 1b. 40c; 1b. $\$ 1.00$.

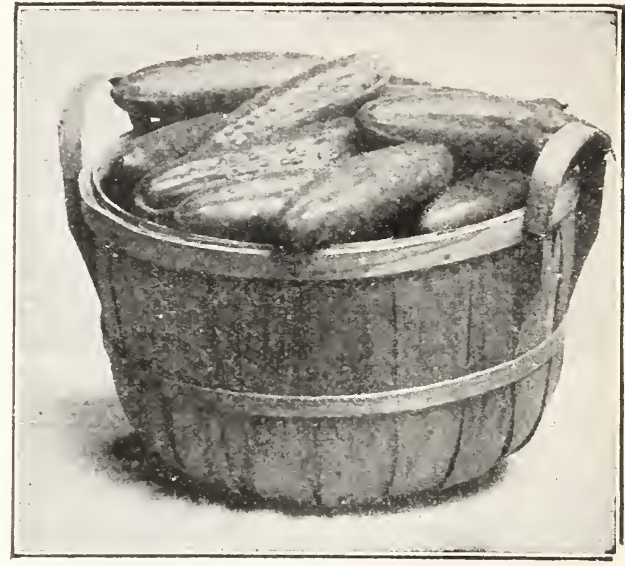

Extra Long White spine

EARLI FORTINE-Holds its dark green color. Extensively used in the South. Parcel Post Paid. Pkt. 5c; oz, 15c; 1/s 1b. 35e; 1b. $\$ 1.00$

EIRLY GREEN CLUSTER-Fruit small and in clusters; very prolific. Parcel Post Paid. Plk. 5c; oz. 15c; 1/4 1b. 35c; 1b. 90e. FIRLY SHORT GREEN (or Early Frame)-Good for pickling; productive. Parcel Post Paid. Pkt. 5c; oz. 15e; 1/4 1b. 35e; lb. $90 \mathrm{c}$.

EXTRI LONG WHITE SPINE-Fruit straight, well formed, measuring 10 to 12 inches long, of a beautiful dark green color. resisting blight when many other varieties fail. Desirable for shipning to distant markets. Parcel Post Paid. Pkt. 5c; oz 15e; $1 / 4$ 1b. $35 \mathrm{e} ; 1 \mathrm{~b}$. $\$ 1.00$.

YEW CENTURY-Distinct sort developed by ourselves. Beautiful shape and color: fine quality. Parcel Post Paid. Pkt. 5c; oz. $15 \mathrm{c} ; 1 / 4$ lb. 35e; $1 \mathrm{~b}$. \$1.25.

ST. LOLIS PICKLING-Very prolific; extensively used by market gardeners. Parcel Post Paid. Pkt. 5e; oz, 15e; 1/4 lb. 40c 1b. \$1.25.

EVERGREEN WHITE SPINE-Retains its deep green color. Large and uniform in size. Parcel Post Paid. Pkt. 5c; oz. $15 \mathrm{c} ; 1 / 4$ lb. $35 \mathrm{c} ; 1 \mathrm{lb} . \$ 1.00$

KLONמHE-Early dark green strain. Fine, shapely fruit. Parcel Post Paid. Pkt. 5e; oz. 15e; 1/4 1b. 35e: 1b. \$1.00.

JIPANESE CLIMBING-Can be grown on trellis. Used for ornament as well as eating. Fruit long and light green. Parcel Post Paid. P'kt. 5e; oz. 15e; $1 / 41 b .35 e ; 1 b . \$ 1.00$.

LONG GREEN-Long and crisp, a popular and reliable variety for pickles. Parcel Post Paid. Pkt, 10c; oz, 25c; 1/4 1b. 65e; 1b. \$2.00.

SMALL GHERTIX-Very small burr, used for pickles. Parcel Post Paid. Plkt. 5e: 0z. 15c; 1/4 lb. 50c; lb. 81.50 .

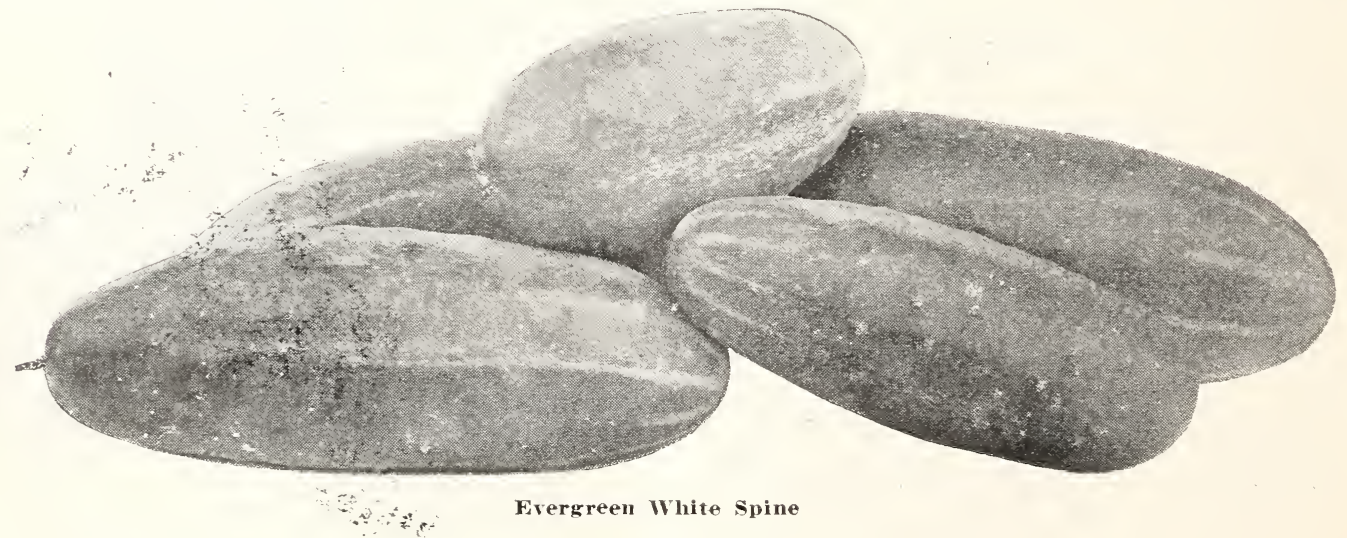




\section{Garden and Sweet Corn}

Sow the seed in a light, rich, dry border as early as the ground can be worked, in drills eight or ten inches apart, and cover the seeds about a quarter of an inch deep rolling them in if the ground be dry.

EARLY WHITE CORY-One of the very best, extra early varieties for market and home garden. Stalks abont 4 feet high, genfor market and home garden. Stalks abont 4 feet high, generally producing two large, finely shaped ears which are fit
for use earlier than most any sort; ears are 12 rowed, 7 to 8 inches long. Parcel Post not prepaid. Pkt. 10c; 1/2 1b. 20c; lb. 30c; 5 libs. \$1.00.

WHIPPLE'S EARLY-A splendid new early variety with the deep grain of the Evergreen type. While maturing 5 days earlier than Early Crosby, it produces an ear nearly as large as Evergreen; ears rather blocky in form, 16 to 18 rows and well filled to the end with pearly white grain of exceptional quality. Parcel Post not prepaid. Pkt. 10e; 1/2 1b. 20c; 1b. 30e; 5 llos. $\$ 1.00$.

KENDEL'S FARLY GIANT-An excellent second early. Ears 8 to 9 inches long and desirable for family or market use. Pareel Post not prenaid. Pkt. 10c 1/2 1b. 20c; 1b. 30c; $51 b s$. ground be dry.

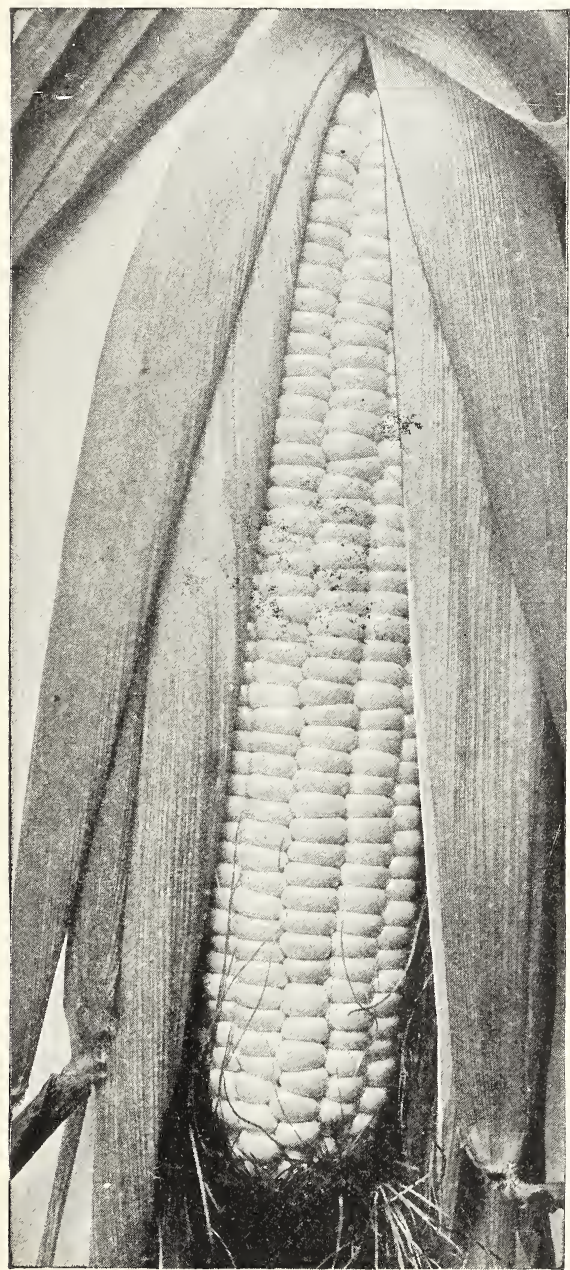

Golden Bantam

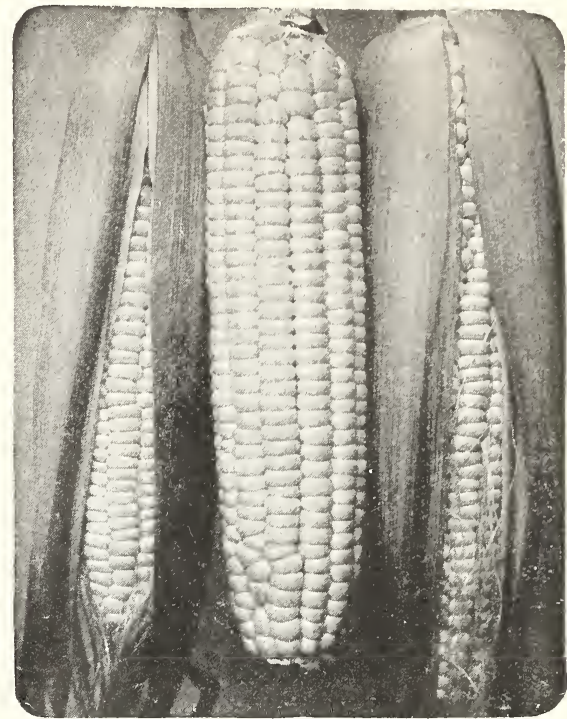

Howling Mol

IOWLING MOB - One of the finest second early large eared sorts very productive, white, and of excellent quality Gars 9 to 10 in. long, 16-rowed Parcel Post not prepaid. Plat 10c; 1/ $1 \mathrm{~b}$ 20e; 1b. 30e; 5 lbs. $\$ 1.00$.

GOLDEN BANTAM SWEET CORN-You know how tender, de licious and sweet Golden Bantam is. Parcel Post not prepaid. Pkt. 10c; 1/2 1b. 20c; 1b. 30c; 5 lbs. \$1.00.

IAMМоти WHITE CORY-A large-eared, second early sort; on the order of Howling Mob, but while a trifle earlier, will not average so large an ear; ears 8 to 9 inches long, 12-rowed. Parcel Post not prepaid. Pkt. 10c; $1 / 2$ 1b. 20c; 1b. 30c; 5 1bs. $\$ 1.00$

HIACK MEXICAN-Well known and a favorite in a great many home gardens, the kernels having a decidedly bluish tinge when ready to eat, later turning to black. It is one of the sweetest varieties in cultivation. Parcel Post not prepaid. Pkt. 10c; 1/2 1b. 20k; 1b. 30c; 5 1bs. \$1.00.

IMPROVED WHITE EVERGREEN-The cobs and kernels are at all stages of edibility beautifully white. The getting rid of the amber tint so prominent in a great many strains of sweet corn passing for Stowell's Evergreen is a great gain, as it fits thi variety for extensive use in canneries. Parcel Post not prepaid. Pkt. 10c; 1/2 1b. 20c; 1b. 30c; 5 lbs. $\$ 1.00$.

HARIY ADAMs-Not a sugar corn, but grown extensively all over the country for market purposes. Parcel Post not prepaid. Pkt. 10e; 1/2 1b. 20c; 1b. 30c; 5 1bs. 90c.

EARLY CHAMPION-A new and very desirable sort; ears nearly as large as Evergreen; pure white; only a few days later thai Minnesota; very fine for market gardeners. Parcel Post not prepaid. Pkt. 10c; 1/2 1b. 20c: 1b. 30c; 5 lbs. \$1.00.

WXTRA EARIY ADAMS-Earliest white corn; small ear and stalk. It is not a Sugar Corn, but is grown for early use. Ear short, kernels very white, Parcel Post not prepaid, Pkt. 10e: 1/2 1b. 20c; 1b. 30c; 5 lbs. \$1.00.

FARLY MINEsot - Five days earlier than the Golden Ban tam. The stalk grows from 3 to $t$ tit in height The ears aver age abont 5 inches in length and are of perfect form, well filled aut to the tip. When cooked, the corn is exceedingly sweet and tonder, 65 days. Parcel Post not prepaid. Pkt. 10e; 1/2 lb. 20e; 11.. 30c; 5 llos. \$1.00.

COUNTRY GENTLEMIN-Small cob; long, slender, white grains, which are very sweet. Parcel Post not prepaid. Pkt. 10c; 1/2 lb. 20c; 1b. 30c; 5 lbs. \$1.00.

STOWVELIS EVERGREEN-The standard and best known Sweet Corn. Ears 8 to 9 inches long, 16 to 18 rowed. with a very deep. sweet grain. Parcel Post not prepaid. Pkt. 10e; 1/2 1b. 20c; lb. 30c; 5 lbs. \$1.00.

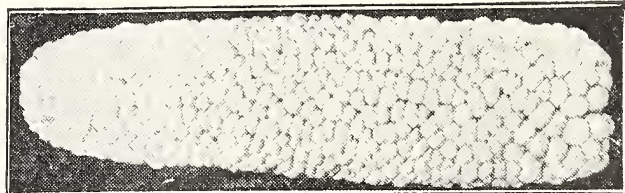

Country Gentleman 


\section{Pop Corn}

Write for special Prices on Large Quantities.

POP CORN-This is the smallest variety of kernels: cultivated same as field or araden corn, but drilled instead of hills. Very extensirely used for pop corn candr. We handle the two best varieties -JAPANEse HeLless or White RiCE. Parcel Post not prevaid. Pkt. 10c; $1 \mathrm{~b}$. 25e; 10 Ibs. \$2.00; 50 lbs. \$6.00.

111 Prices in this Catalog are subject to Market Fluctuations.

\section{Endive}

This plant furnishes an attractive and appetizing salad for the fall and winter months, or by repeated sowing a suply may be had nearly all the year around.

GREEN CURLED WINTER-Standard sort for fall and winter crop. Parcel Post Paid. Pkt. je; oz. 15e; 1/4 1b. 50c: 1 1b. \$1.50.

BATAVIAN-Forms large heagls that may be blanched. Also used for greens. Parcel Post Paid. P'kt. je; oz. 15e; 1/4 1b. 50c; lb. \$1.50.

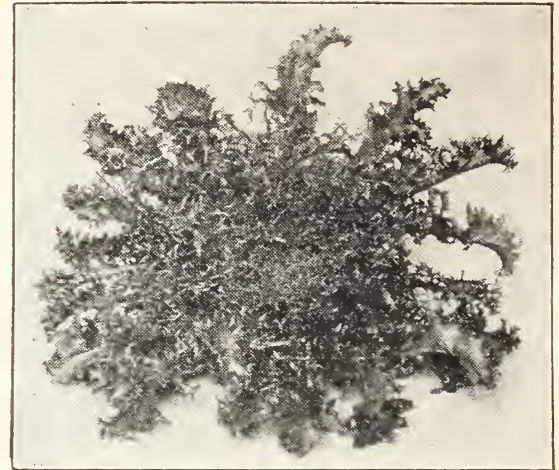

Endive

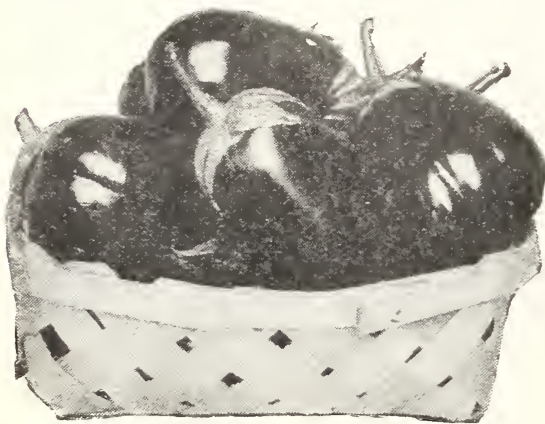

Black Beauty Egg Plant

\section{Egg Plant}

CILTIRE-Egg Plant seed should be sown in hot-beds in March or April and transferred to pots or boxes when an inch or two high and planted out early in June in rows 21/2 feet apart each way, culivation same as for cabbage.

IBLACK BEATTY-Fruit broad and thick, rich deep black, spineless, very early. Parcel Post Paid. Pkt. 10c; oz. 40c; 1/4 1b. \$1.50.

IMPROVED NEW YORK PURPLE-The best large oval, deep pur ble, grown more extensively than any other sort. Parcel Post Paid. Plit. 10e; oz. toe; $1 / 4$ ib. \$1.50.

THORYLES OR SMOOTH STEM-Fruit early, very large, oval and of a fine dref purple. Parcel Post Paid. Pkt. 10c; oz. 50e; 1/4 11). $\$ 1.75$.

\section{Kale}

CORNELI'S SLOW SEEDER-Dwarf green curled; will stand longer than the other sorts before running to seed. Parcel Post Paid. Plit. 5e; oz. 10e; 1/4 1b. 30c; 1b. 90e.

DWARF GERMAN GREENS-An improred strain, of dwarf spreading habit. beautifully curled, very hardy and much in clemand for spring and Fall sowing. Sow in September for spring use. Parcel Post Paid. Pkt. 5c; oz. 10c; 1/4 1b. 25e; 1 1b. รั้

OSTRICH PLIME-Ornimental: rather broad, extremely curled leaves. Parcel Post Paid. Pkt. 5e; oz. 15e; 1/4 Ib. 40c; 1b. \$1.25.

TALL GREEY CLRLED NCOTCH-Grows about 18 inches high and spreads. Bright green leaves, beautifully curled. Parcel Post Paid. Plit. 5e; oz. 15e; 1/4 lb. 40e; 1 lb. \$1.10.

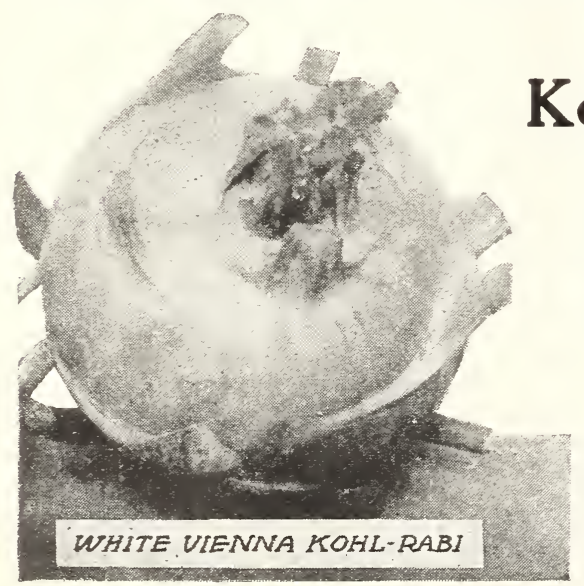

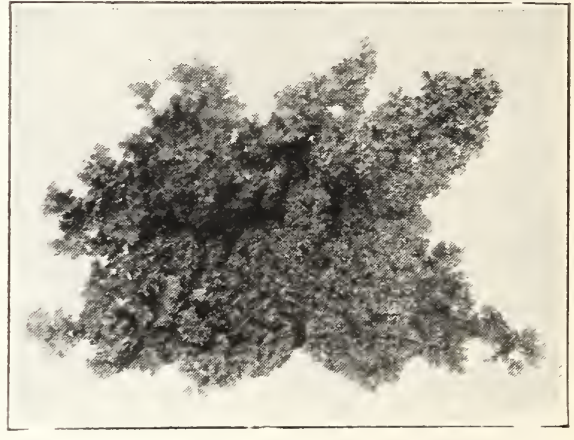

Iiale

( ILTCRE-Sow the seed in the spring in drills three-fourths of an inch deep and 2 feet apart and when the plants are a few inches high thin to 12 inches. Cultivate same as heets.

EARLY WHITE VIENy-Handsome and delicate. white ball. Parcel Post Paid. Plkt. 10e; oz. 25e; 1/4 1b. 55e; 1 lb. \$2.50.

EARIS PI RPLE VIENXA-Very sood soth Parcel Pont Paid. Pkt. 10e; oz. 25e: 1/4 lb. 5.5e; 1 lb. \$?.50.

\section{Leek}

CLLTCRE-Sow seed in early spring in rows 1 foot apart and 1 inch deep. Then 6 inches high, transplant $t$ to 6 inches apart in rows 12 inches apart. setting plants in the ground up to their center leaves and as they grow draw the soil up around them.

BEST LARGE FLAG WIXTER-Hardy and productive. Parcel Post Paid. Pkt. 5̃e; oz. 15e; 1/4 Ib. 50c; ib. \$1.75.

L.IRGE MCSELBURGH-Leaves large and broad, flavor mild and pleasant. Parcel Post Paid. Pkt. 5e; oz. 15e; 1/4 Ib. 50c; Ib. \$1.75.

\section{HERBS-Sweet, Pot and Medicinal}

\section{Price} Parcel Post Paid

Anise

Basil Sweet

Borage

Caraway

Catnip .... 'er P'kt. Per Oz.

$\begin{array}{ll}10 \mathrm{c} & 20 \mathrm{c} \\ 10 \mathrm{c} & 20 \mathrm{c} \\ 10 \mathrm{c} & 25 \mathrm{c} \\ 10 \mathrm{c} & 15 \mathrm{c} \\ 10 \mathrm{c} & 40 \mathrm{c} \\ 10 \mathrm{c} & 20 \mathrm{c}\end{array}$

\section{Price}

Per Pkt. Per Oz.

Dill ...........................

Fennel Sweet ….........10c

Horehound .................10

Lavender …................... $10 c$

$15 \mathrm{c}$
$20 \mathrm{c}$
$25 \mathrm{c}$
$30 \mathrm{c}$
$30 \mathrm{c}$
$50 \mathrm{c}$

Price

Parcel Post Paid Per l'kt. Per Oz.

Sage

Savory summer $10 c \quad 50$

Sweet Marjoram ….....10c

Thyme Broad Leared

English .................10 


\section{Lettuce}

CULTURE-Sow in the house or in frames any time after Mareh 10th; if put outdoors, as early in the spring as ground can be worked and at intervals of two weeks till June 1st, Soil should be a rich, sandy loan with plenty of humus. Rows to be $11 / 2$ feet apart, plants two inches apart in low after thinuing Two ounces of seed will sow 150 feet of row, 4 to 5 pounds required per acre.

BIG BOSTON-The best large headiug early variety. Most popular variety for the southern gardener who ships north. Also very valuable as first early in the North. Plants are large, vigorous; leaves bright, light green, very tender. Our strain is unsurpassed. Many gardeners in the South will plant only the Big Boston. Parcel Post Paid. Pkt. 5c; 0z. 15e; $1 / 4$ lb. 50c; 1b. \$1.50.

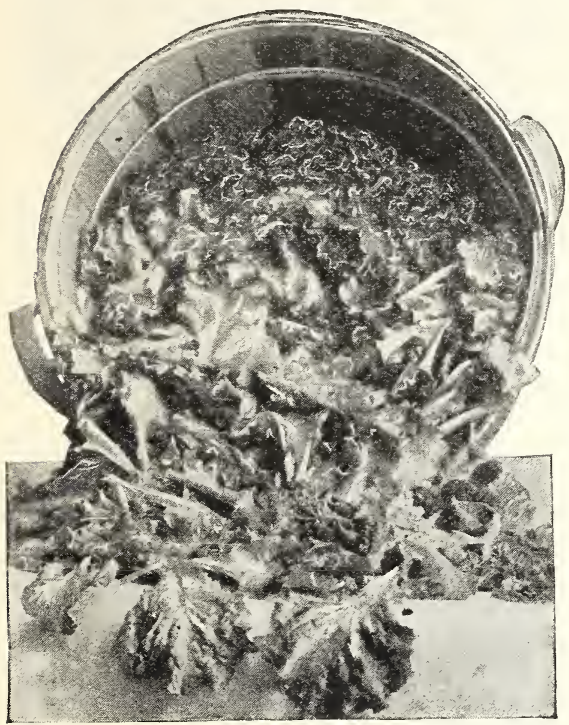

Black Seeded Simpson

Ready for Use in 40 to 60 Days.
BLACK SE E E D S I M P S O N (B. S.) One of the best and most popular large, early, loose - heading varieties, succeeding everywhere and alw a y s dependable; leaves broad much crumpled and frilled. Parcel Post Paid. Pkt. 5e; oz. 15e; 1/4 1b. 50c; 1b. \$1.50.

CALIFORNIA CREAM BUTTER - Round, solid heads, medium green, good size, compact, rich buttery taste Pareel Post Paicl. Plat. 5e; 0z, 15e; 1/4 lb. 50c; lb. \$1.50.

NEW YORK WONDERFUL-Large solid heading variety. The in ner portion is a beautiful white, the outer leaves are dark green good shipper. Pkt. 10c; oz. 30c; 1/1 1b. 85e; 1b. \$2.50. Parcel Post. Paid.

EARLY CURLED SIMPSON-An early, erect growing, clustering $\nabla \boldsymbol{a}$ riety, which may be sown very thick and cut while the plants are very young, at which time they are exceedingly tender, sweet and well flavored; color light green. Parcel Post Paid. Pkt. 5c; oz. $15 c ; 1 / 4$ lb. 50e; lb. $\$ 1.50$.

EARLY PRIZE HEAD-Bright green tinged with brownish red, tender, crisp. Parcel Post Paid. Pkt. 5e; oz. 15e; 1/4 1b. 50c lb. \$1.50.

GRAND RAPIOS FORCING-Targe, tender heads, one of the best for early forcing. Parcel Post Paid. Pkt. 5e; oz. 15c; 1/4 1b. 50c 1 1b. $\$ 1.50$.

ICEBERG-Fine compact heads which resist summer heat admir ably; is very popular; leaves curled and light green; crisp, tender. Parcel Post Paid. Pkt. 10c; 0z, 20c; 1/4 1b.65e; 1 lb. \$2.00.

IMPROVED HANSON-Very large and solid, sweet, crisp and tender.

Parcel Post Paid. Pkt. 5c; oz. 15c; 1/4 1b. 50c; lb. $\$ 1.50$.

TRIANON COS (Romaine) (W. S.)-Has smooth, long, narrow, upright leaves; blanches nicely when tied up, making a firm, loaf shaped head; quality fine. Parcel Post Paid. Pkt. 5e; oz. 15e $1 / 4$ 1b. 50c; $1 b$. \$1.50.

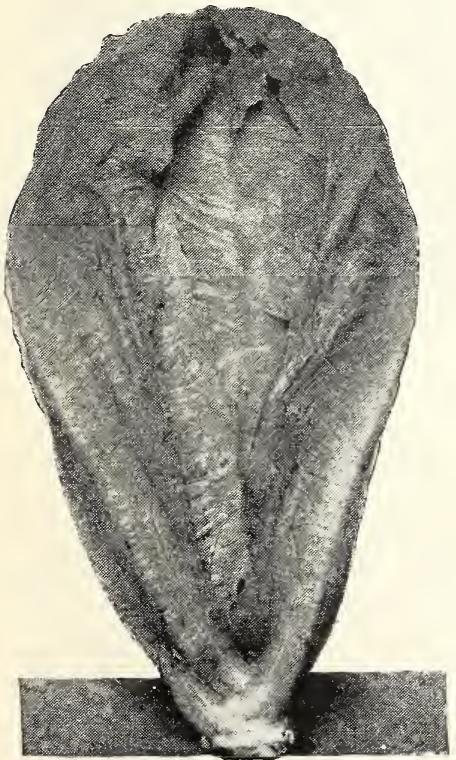

Trianon Cos
ST, LOUIS MARKET-Popular variety for summer planting. Parcel Post Paid. Pkt. 5e; oz. 15c; 1/4 1b. 40c; 1b. $\$ 1.25$.

IVAYAHEAD (W, S.) -A ver early rather small, handsome compact heading riety with medium green riety with medium green leaves and a rich, butteryity. Parcel Post Paid. Pkt. 5̆c; 0z. 15c; $1 / 4$ lb. $50 \mathrm{c} ; 1 \mathrm{lb}$. $\$ 1.50$

PALMER'S BLACK SETDED FORCING - For forcing

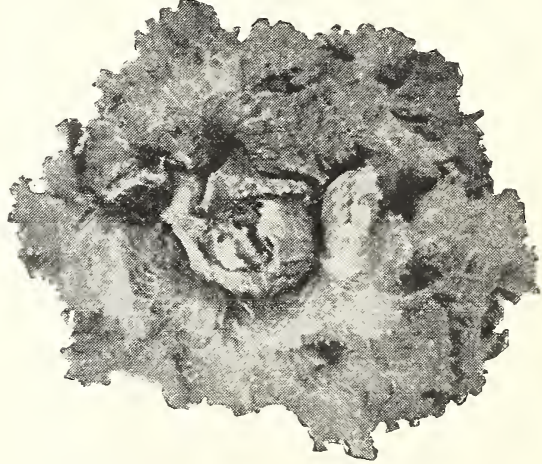

Iceberg also for early outdoors; forms very compact, solid heads. Parcel Post Paid. Pkt. 5e; oz. 15e; 1/4 1b. 40e; 1b. \$1.50.

\section{Mustard}

SOUTHERN GIANT CURLED-Leaves are large, light green with yellowish tinge, much crimped and frilled at the edges. Very succulent, pungent and of sweet flavor. Parcel Post Paid. Pkt. 5c; oz. 10e; 1/4 lb. 25e; 1b. 65e; 5 lbs. $\$ 3.00$.

WHITE LONDON-Plant of rapid, upright growth, soon going to reed small and smooth, deeply cut or divided; color dight yellow. Parcel Post Paid. Pkt. 5c: deep green; seed large, light yellow.

ICK leaves oblong, broad and cut; seed reddish-brown. Parcel Post Paid. Pkt. 5c; oz. 10e; 1/4 1b. 25e; 1b. 65e; 5 lbs. $\$ 3.00$.

FORDHOOK FANCY-A handsome, vigorous growing, mild variety, standing a long time before going to seed; leaves dark green, beautifully curled and fringed; fine for salads and garnishings. Parcel Post Paid. Pkt. 5c; oz. 10e; 1/4 1b. 25e; 1b. 65c; 5 lbs. $\$ 3.00$. 


\section{Muskmelons, or Cantaloupe}

ROCKY FORD-One of the most popular. Just right size for restaurant and hotel service: flesh is green, thick, and lusciously sweet. It is netted and ribbed and ripens early. Parcel Post Paid. Pkt. 5e; oz. 10c; 1/4 1b. 30c; 1b. 90c.

FMERALD GEM-Unquestionably one of the best and earliest melons for home garden and local markets and in our opinion the best for quality; of medium size, a flattened globe in form, irregularly and distinctly ribbed and lightly netted; color deep emerald green; flesh very thick, sweet and of rich salmon color; seed cavity exceedingly small. Parcel Post Paid. Pkt. 10c; oz. 20c; 1/4 1b. 40c; 1b. $\$ 1.25$.

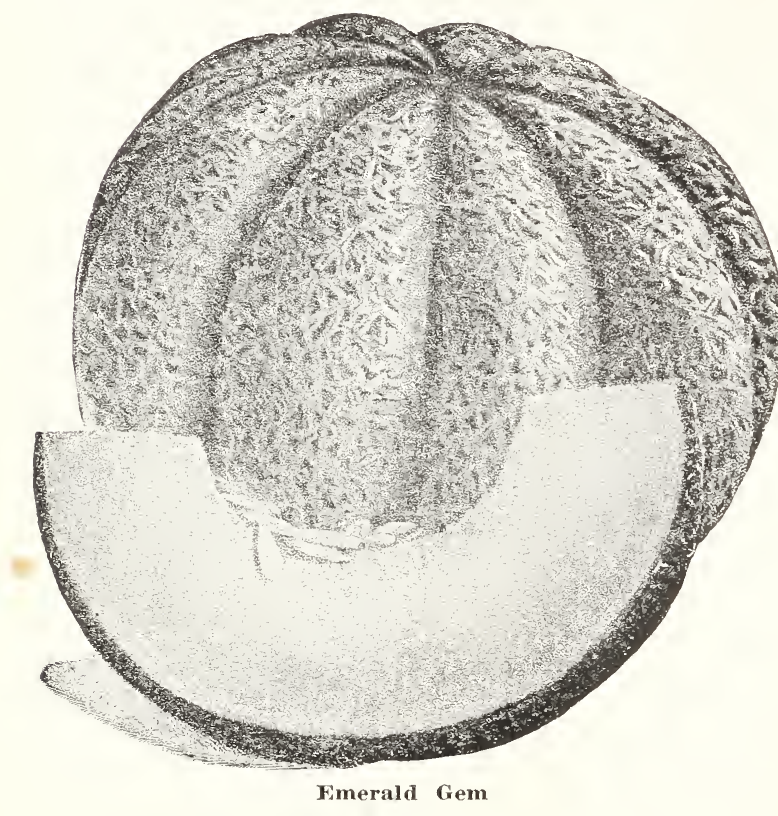

Fmerald Gem

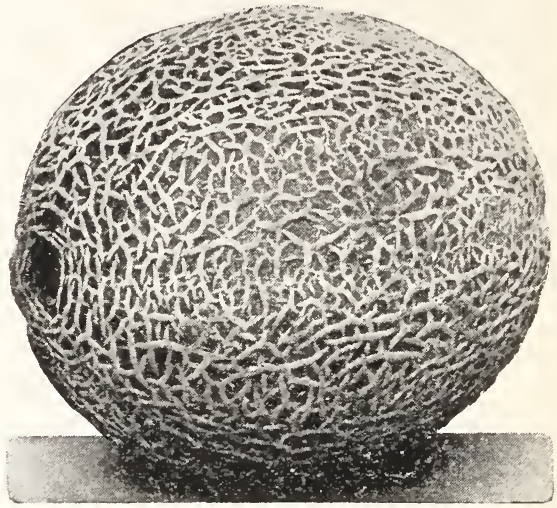

Burrell's Gem

FARLY GREEN NUTMEG-An early variety of medium to a small size; nutmeg in shape and thickly netted. Parcel Post Paid. Pkt. 5c; oz. 10c; 1/4 lb. $30 \mathrm{c} ; 1 \mathrm{~b} .90 \mathrm{c}$.

POLLOCK 10-25-The salmon or pink meat Rocky Ford combining earliness in addition to the good qualities of the Green Flesh Rocky Ford melon. Parcel Post Paid. Pkt. 5c; oz. 10c; 1/4 1b. 30c; lb. $90 \mathrm{c}$.

HEARTS OF GOLD-An improved type of the Hoodoo, being somewhat larger and slightly more oblong. A most excellent, small, mid-season variety fruit rownd, with tendency to heartshape, dis-' tinctly ribbed and densely covered with a fine gray netting. Flesh very thick, of splendid quality and rich orange color; ripens thoroughly to the rind and has a very small seed cavity. Pkt. 10c; oz. $25 \mathrm{c} ; 1 / 41 \mathrm{lb} .50 \mathrm{c} ; 1 \mathrm{~b} . \$ 1.50$.

TIP TOP-Nearly round, deeply ribbed, moderately netted; flesh is bright salmon, thick and of good flavor... Pkt. 5c; oz. 10c; 1/4 1b. 30c; 1b. 90c. Parcel Post Paid.

BANANA-Long, shaped like a banana; has a most delicious flavor. Parcel Post Paid. Pkt. 5c; oz. $10 \mathrm{c} ; 1 / 4$ 1b. 30c; $1 \mathrm{~b} .90 \mathrm{c}$.

OSAGE-Fruit medium size to large, nearly round, slightly ribbed. dark green, almost smooth. Flesh very thick, deep salmon and of the finest quality. Parcel Post Paid. Pkt. 5c; oz. 10c; 1/4 1b. 30c: 1 1b. 90c.

EXTRA EARLY HACKENSACK-(Green flesh)-In shape and color it is similar to Hackensack. Matures earner, in avout bo days. It is a round melon, flattened on the ends and well ribbed. The skin is netted, and the green flesh is rich and sugary. Parcel Post Paid. Pkt. 10c oz. 20c; 1/4 1b. 30c; 1b. 90c.

ST. LOUIS MARKET-Nutmeg shaped; rich aromatic flavor, greenish yellow flesh: solid; juicy, fine netted, strong rind. Parcel Post Paid. Pkt. 5c; oz. 15c; 1/4, 1b. 40c; 1b. \$1.25.

HONEY DEW MELON-A splendid new variety; rind dull white when ripe. The flesh is a rich green, very sweet and delicious flavor. The average size is about six inches in diameter and they weigh five to six pounds. The skin is smooth with little netting. Parcel Post Paid. Pkt. 10c; oz. 15c; 1/4 1b. 30c; 1b. 90c.

BURRELL'S GEM-Skin is rather dark green and rind thin, leaving a thick lining of salmon flesh, which is of most delicious, juicy flavor. Parcel Post Paid. Pkt. 10c; oz. 15e; 1/4 1b. 30c; 1b. 90e.

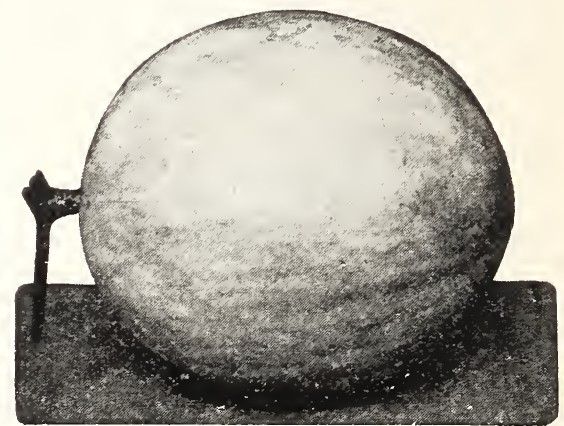

Honey Dew

\section{Okra}

One Ounce Will Plant 100 Hills-This plant is extensively cultivated for its green pods, which are used in soups and stews and are very wholesome and nutritious. Sow about the first of May, in drills 3 feet apart, and thin out the plants to one foot apart. Soak seeds in water 12 hours-they germinate easier.

DWARF GREEN-Very early; pods green and tender. Parcel Post Paid. Pkt. 5c; oz. 10c; 1/4 1b. 25c; 1b. 80c.

MAMMOTH POD--This variety is about three feet high, very early and productive. Pods deep green, very long, slender, slightly corrugated, very tender and of good quality. Parcel Post Paid. Pkt. 5c; oz. 10c; 1/4 1b. $25 \mathrm{c} ; 1 \mathrm{~b} .80 \mathrm{c}$.
WHITE VELVET-This Okra takes its name from the smoothness of its pods, which are round, differing in this respect from the old sort. Parcel Post Paid. Pkt. $5 \mathrm{c}$; oz. 10c; $1 / 4$ 1b. 25c; 1b. 80c.

TALL OR LONG GREEN-Long ribbed pods, very productive. Parcel Post Paid. Pkt. 5c; oz, 10c; 1/4 lb. 25c: 1b. 80c. 


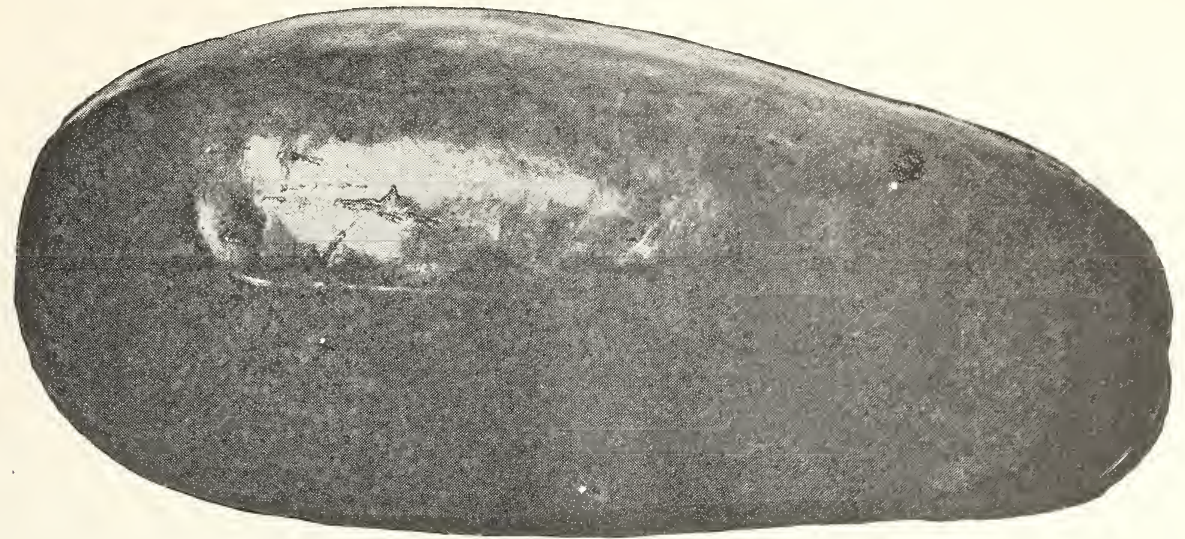

Halbert Honey Watermelon

\section{Watermelons}

ALABAMA sWEET-The flesh is bright red, fine grained, sweet and luscious. Parcel Post Paid. Pkt. 5c; oz. 10c; $1 / 4$ lb. $30 \mathrm{c}$; $1 \mathrm{~b}$. 75e.

FLORIDA FAVORITE-Oblong in shape, growing to a very large size; rind dark green striped with lighter; highly prized on account of its delicious flavor: seed light color. Parcel Post Paid. Pkt. 5c; oz.10e; $1 / 4$ 1b. 30e; 1b. \%5c.

GEORGIA RATTLESNAKE-A large striped variety of oblong shape; flesh scarlet and of superior quality. Parcel Post Paid. Pkt. 5e; oz. 10c; 1/4 1b. 30c; 1b. F5e.

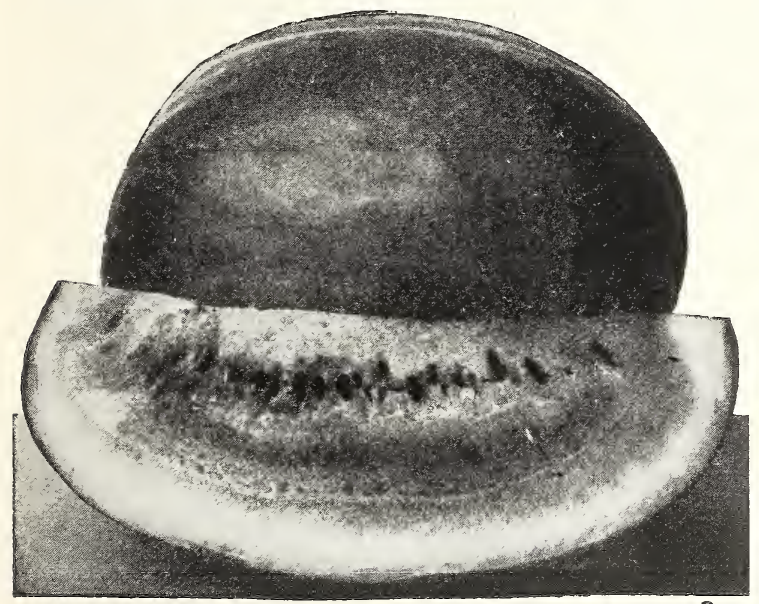

Sweetheart

KLECKLEY's SWEET-The best melon grown. Oblong, very large, dark green, faintly striped, very sweet, entirely stringless; very prolific. Parcel Post Paid. Pkt. 5c; oz. 10c; 1/4 1b. $30 \mathrm{c} ; 1 \mathrm{~b}$. 75c.

HALBERT HONEY-The melons average eighteen to twenty inches long and are full or bluntly rounded at both ends. The skin is a dark, glossy green. The flesh is a beautiful crimson, the rich coloring and luscious quality extending to the thin rind. Parcel Post Paid. Pkt. 5c; oz. 10c; 1/4 1b. 30e; 1b. 85c.

TOM WATSON-Long, green and very prolific. The melons are uniformly large, running from 30 pounds to 40 pounds. The flesh scarlet, of extra fineness and sweetness, entirely stringless. fairly melts in your mouth. The rind is exceptionally strong, making it an excellent shipper. Parcel Post Paid. Pkt. 5e; oz. 10c; $1 / 4$ lb. 25c; 1b. 60c.

PEERLESS, or ICE CREAM-A fine early, medium sized melon ; one of the best for home gardens; short oblong in form, light green, mottled a darker shade. Parcel Post Paid. Pkt. 5e; oz. $15 \mathrm{c} ; 1 / 4$ 1b. 35c; 1 b. 90c.

DIXIE-Fruit long, skin dark green striped with a lighter shade. Flesh bright scarlet, rind thin but tough. Parcel Post Paid. Pkt. 5c; oz. 10e; $1 / 4$ 1b. 30c; 1b. 75c.
RIH GREY" WATERMELON (Also called General Pershing)-The size of this melon is uniformly large and it closely resembles Kleckley's Sweets except the and firm, without hard center, brilliant sparkling red. Rind almost as tough as a citron, making a grand shipper. Earlier than Tom Watson, Irish Grey Pet with universal favor. Parcel Post Pkt. 5c; 0z. 10c; 1/4 1b. 30c; 1b. 75c. deep red and of the finest quality. Parcel Post Paid. ; 0z. 10c; $1 / 4,10.30 \mathrm{c} ; 10$. $75 \mathrm{c}$.

HURMOND GRAY-A new greenish Gray Melon, grows very large, does not sunbake easily, and the best shipper that grows. The flesh is bright red, finely flavored, solid and sweet. On account of its color, large size and fine eating qualities it is $A$ decided improvement on the regular Irish Grey. Parcel Post Paid. Pkt. 5e; oz. 15c: 1/4 1b. 40c; $1 \mathrm{~b}$. \$1.25.

FORDHOOK FARLY-Adapted for home garden and local markets; an extra early variety of fair size and fine quality; skin deep green, mottled a darker shade. Parcel Post Paid. Pkt. 5c; oz. 10c; 1/4 1 b. $30 \mathrm{c}$; 1b. $75 \mathrm{c}$.

KOLB'S GEM-An old standard shipping melon of large size; nearly round in form with a dark green rind, striped lighter shades. Parcel Post Paid. Pkt. 5c; oz, 10e; $1 / 4$ lb. 30e; 1b. $75 c$.

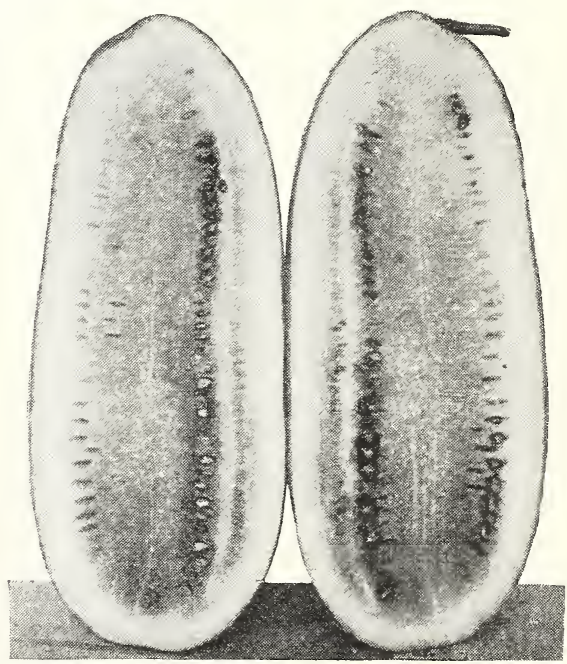

Kleckley Monte Cristo 


\section{Onion Seed}

One ounce of seed will sow 75 feet of drill; it will take 4 to 5 pounds to the acre to grow large onious. If sets are wanted, 50 to 60 pounds should be sown on an acre.

EARLY RED FLAT-Color of Wethersfield, early. Parcel Post Paid. Pkt. 10c: oz. 20c; 1/4 1b. 60c; 1b. \$1.50.

GLOBE IYETHERSFIELD-Cross between Red Wethersfield and Large Red Globe; beautiful onion, fine keeper, fine for the market gardener. Parcel Post Paid. Pkt. 10c; oz. 20c; 1/4 lb. 60c: $1 \mathrm{~b} . \$ 1.50$

IARGE RED WETHERSFIELD-Medium ear's and a good keeper; standard sort. Parcel Post Paid. Pkt. 10e; oz. 25e; 1/4 1b. $65 \mathrm{e} ; 1 \mathrm{~b} . \$ 2.00$.

LARGE RED GLOBE-Southport strain, one of the best reds, good keeper. Parcel Post Paid. Pkt. 10c; oz. 25c; 1/4 lb. 60c; ib. $\$ 2.00$.

LARGE White Portugal-Standard sort, flat, Parcel Post Paid. Pkt. 10c; oz. 30c; 1/4 lb. 75e; 1b. \$2.75.

LARGE White GLoBE-Large Southport strain. Parcel Post Paid. Pkt. 10c; oz. 40c; 1/4 1b. 90c; lb. $\$ 3.25$.

LARGE YELLOW GLOBE-Southport strain, large, firm, mild, good keeper. Parcel Post Paid. Pkt. 10c; oz. 20c; 1/4 1b. 75c; Jb. \$2.25.

PRIZETAKER-Very large beautiful onion, white flesh, skin straw color: sweet, mild and tender.... Parcel Post Paid. Pl. $10 \mathrm{c} ;$ oz. $20 \mathrm{c} ; 1 / 4$ 1b. 75e; 1b. \$2.25.

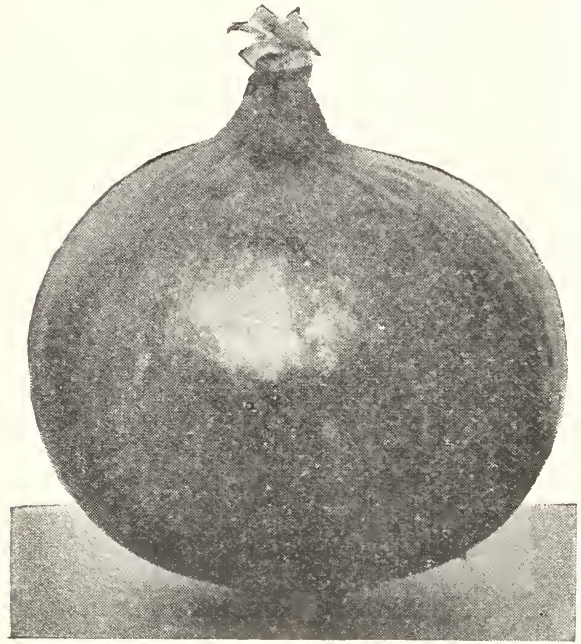

Red Globe Wethersfield

\section{Onion Sets}

Prices are subject to market fluctuations. When you want large quantities ask for market prices. Thirty-two pounds constitute a bushel.

Plant 4 to 6 inches apart in 12 to 24-inch rows (except Potato, Onions, which should be in 2 -foot rows.) Plant in Spring or Fall in fine rich soil, well mánured.

RED WETHERSFIELD-Quart 20c; gallon 60c; peck $\$ 1.00$. Parcel Post Paid.

YELLOW IN IVERS-Quart 20e; gallon 60e; peck \$1.00. Parcel Post Paid.

WHITE SILVER SKIX-Quart 30e; gallon 90e; peck \$1.50. Parcel Post Paid.

WHITE MULTIPLIER SETS-Quart 30c; gallon $\$ 1.00$; peck $\$ 2.00$.

Parcel Post Paid.

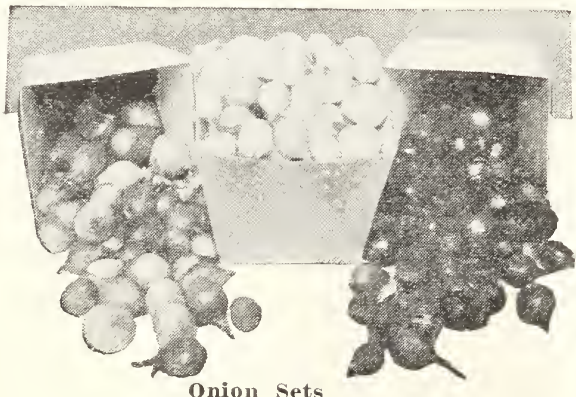

Onion Sets

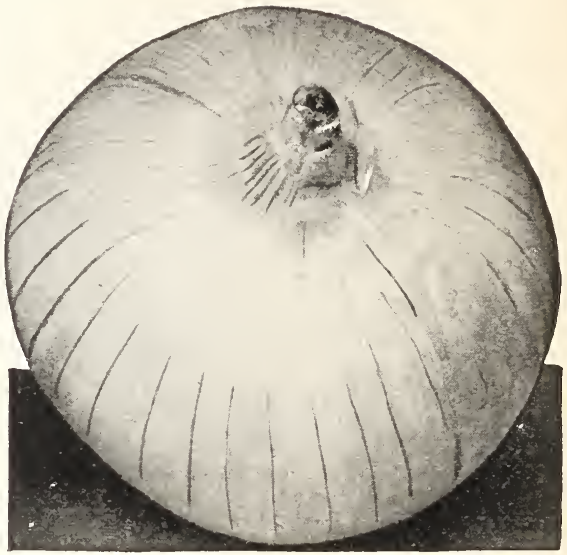

White Silver Skin

IIIO YELLOW GLOBE-Most handsome globe onion with a age from 2 to $21 / 2$ inches in diameter and ripen a little earlier Ib. $5 \mathrm{c} ;$ ib. 22.25

ELLOW DANVERS (Flat)-A standard sort, rather oval, early, 200d keeper. Parcel Post Paid. Pkt. 10c; oz. 25e; 1/4 1b. 75c;

ELLOW GLOBE DANVERS- Of more globular shape; keeps well. Parcel Post Paid. Pkt. 10c; oz. 25e; 1/4 lb. 75c; lb. \$2.00.

HITE \&ILVER SKIN-Pure white: mild flavor; best for grow-

IAMMOTH SILVER KING-Very large; white skin and flesh; mild flavor, flat shape: frequently weigh 3 pounds. Parcel Post Paid. Pkt. 10e; oz. 25e; 1/4 1b. 75̃e; 1b. \$2.50.

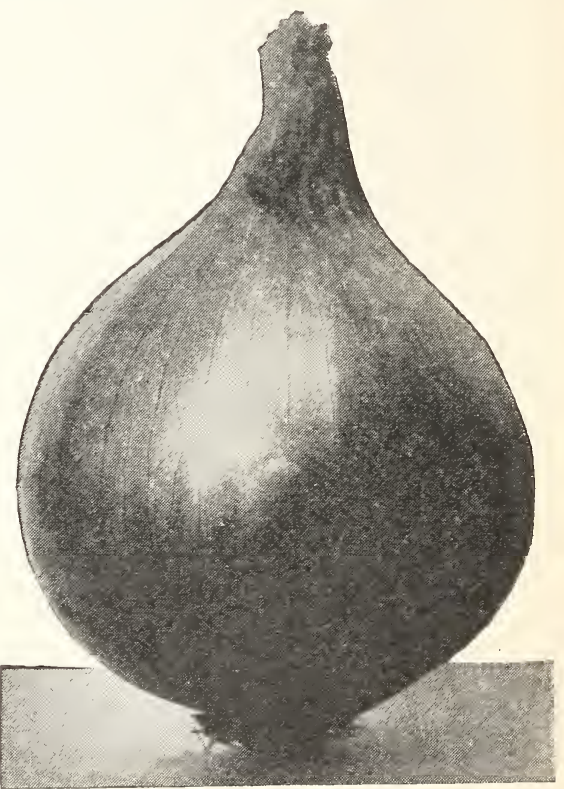

Ohio Yellow Globe

IY YOUR HOME GARDEN

"Dig deep, manure well, work often" Thus Pliny the Elder, nearly 2,000 years ago, summed up gardening. His advice is good today. 


\section{Parsley}

CULTURE-Soak seed in water for a few hours and sow in rich soil early in spring in rows a foot apart and cover lightly. Parsley is slow to germinate and is sometimes 3 or 4 weeks in coming up. One ounce will sow 150 feet of drill. Sow in March and April, also in September.

CHAMPION MOSS CURLEO-More densly crimped and curled than some other sorts. Parcel Post Paid. Pkt. 5e; oz. 10c; 1/4 1b. 30c; 1b. 85 c.

DOLBLE CURLED-Pkt. 5e; oz. 10c; 1/4 1b. 30c; lb. 85e. Parcel Post Paid.

HAMBCRG OR ROOTED-Edible roots, much like parsnips. Parcel Post Paid. Pkt. 5e; oz. 10e; 1/4 1b. 30e; lb. 85e.

\section{Parsnip}

SUGAR OR HOLLOU CROWN-The best for table use; easily raised and of great productiveness. Pkt. 5c; oz. 10c; 1/4 1b. 25c; 1b. 75c Parcel Post Paid.

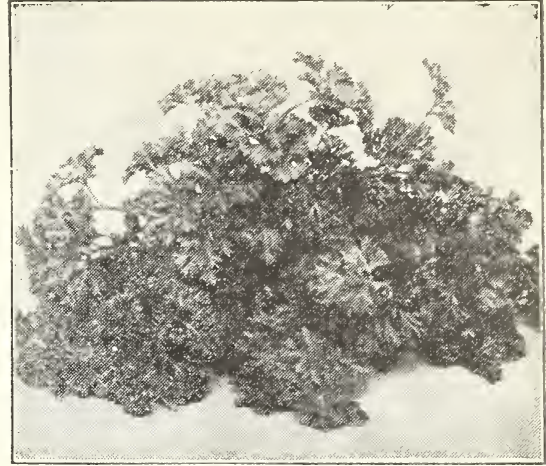

Champion Moss Curled Parsley

\section{Peas}

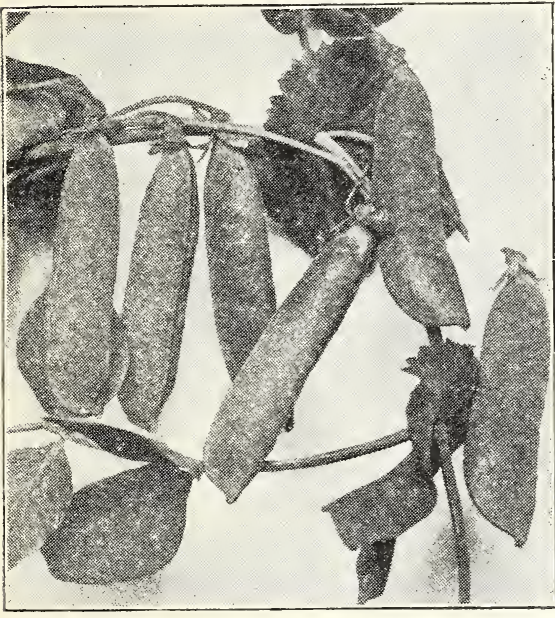

Laxtonian Peas
I.AXTONIAN PEAS - The best of all Dwarf Peas. Produces finest quality. Parcel Post not prepaid. Pkt. 10c; 1/2 lb. 20c: lb. $35 \mathrm{c} ; 5$ lbs. \$1.25.

GRADUS OR PROSPERITY-Ripens early; vines about 3 feet high; bears profusely. The pods almost as large as those of Telephone. Parcel Post not prepaid. Pkt. 10c; 1/2 1b. 20c; lb. 35e; 5 1bs. \$1.25.

SUTTON'S EXCELSIOR-The Finest Dwarf Wrinkled Extra Early Variety - It is the best of recent introductions: vines are larger and more vigorous than the American Wonder, while the pods are fully one-third larger, containing six to eight fine, large peas, packed so closely together in the pods that the peas are always more square than round. The pods are always well filled with peas, which in sweetness and quality have no equal, being superior to any other wrinkled sort. Parcel Post not prepaid. Pkt. 10c; 1/2 1b. 20c; 1b. 35c; 5 1bs. \$1.25.

NO'TT'S EXCELSIOR--A strong, vigorous grower and continues to bear for a long time. Height 15 inches. Parcel Post not Prepaid. Pkt. 10c; $1 / 2$ lb. 20c; 1b. 30c; 5 1bs. $\$ 1.20$.

CHAMPION OF ENGLAND-It grows 4 to 5 feet high and requires support, and large crop production more than repays any extra labor required. Parcel Post not prepaid. Pkt. 10c: $1 / 2$ 1b. 20c; 1b. 30c; 5 lbs. \$1.20.

ALASKA-The earliest of all the extra early sorts; vines about 2 feet in height. The pod is about 3 inches long, well filled with uniformly round peas. Parcel Post not prepaid. Pkt. 10c; 1/2 1b. 20c; 1b. 30c; 5 1bs. $\$ 1.20$.
*THOS. LAXTON-The only rival to the famous Gradus, as a long-podded, extra or extremely early wrinkled pea, and in some respects even better. The growth is identical, but the pods are a deeper, richer green and square at the end. In the judgment of deeper, rin flavor, while as the large peas are of a deeper green they present a more as the large peas are of a deeper green they present a more Pkt. 10c; 1/2 1b. 20c; 1b. 30c; 5 1bs. $\$ 1.25$.

BLISS EVERBEARING-A good variety that continues in bearing a long time. A general favorite. Height 3 feet. Parcel Post not prepaid. Pkt. 10c; $1 / 2$ lb. 20c 1b. 30c; 5 1bs. $\$ 1.20$.

TELEPHONE*-The vines are tall, about four feet high, with large leaves, and producing an abundance of pointed pods of largest size, often four and one-half to five inches long, filled with very large peas, which are tender and sweet. Parcel Post not prepaid. Pkt. 10c; 1/2 1b. 20c; lb. 30c; 5 lbs. $\$ 1.20$.

AMEER-Extra early, large dark green pods, very productive. Height $2 \frac{1}{2}$ feet. Parcel Post not prepaid. Pkt. 10c; 1/2 1b. 20c; 1b. 30c; 5 lbs. \$1.25.

LARGE PODDED ALASKA-Larger than Alaska and five days later, a splendid early market variety. Parcel Post not prepaid. Pkt. 10c; 1/2 1b. 20c; 1b. 30c; 5 lbs. \$1.25.

BLUE BANTAM-An extra early prolific sort, producing large pods containing 8 to 9 peas of the most delicious flavor. Height 15 inches. Parcel Post not prepaid. Pkt. 10e; 1/2 1b. 20c; 1b. 85e; 5 lbs. \$1.50.

AMERICAN WONDER-An old standard, very dwarf, extra early sweet pea, growing about 1 foot high. Parcel Post not prepaid. Pkt. 10c; 1/2 1b. 20c; 1b. 30c; 5 lbs. $\$ 1.20$

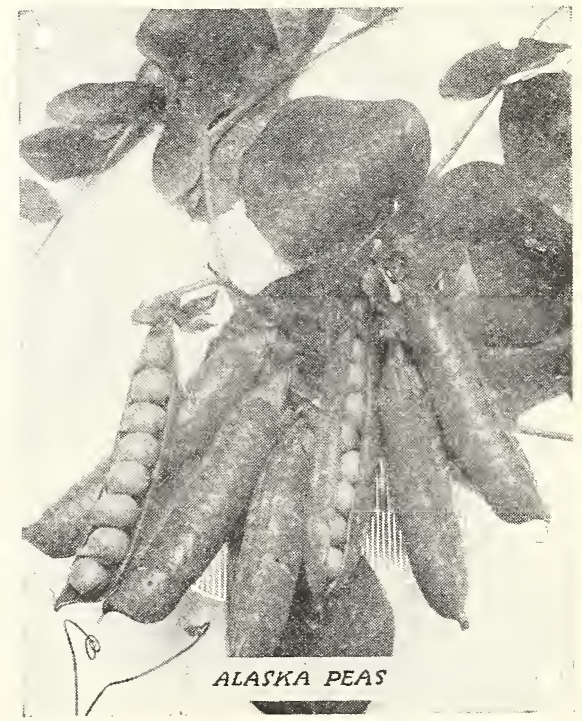




\section{Irish Potatoes}

EARLY RED TRIUMPH-One of the best early potatoes, combining the productiveness of the White Star with the excellent qualities of Irish Cobbler. A most valuable early variety for the South, and a dependable producer and ready seller. It withstands drouth. Matures in about ten weeks. Medium size, round very uniform in shape; eyes slightly depressed and color of a beautiful light red and is a standard variety for shipping. Parcel Post not prepaid. $15 \mathrm{lbs}$. $\$ 1.00 ; 60 \mathrm{lb}$. bu. $\$ 3.25$.

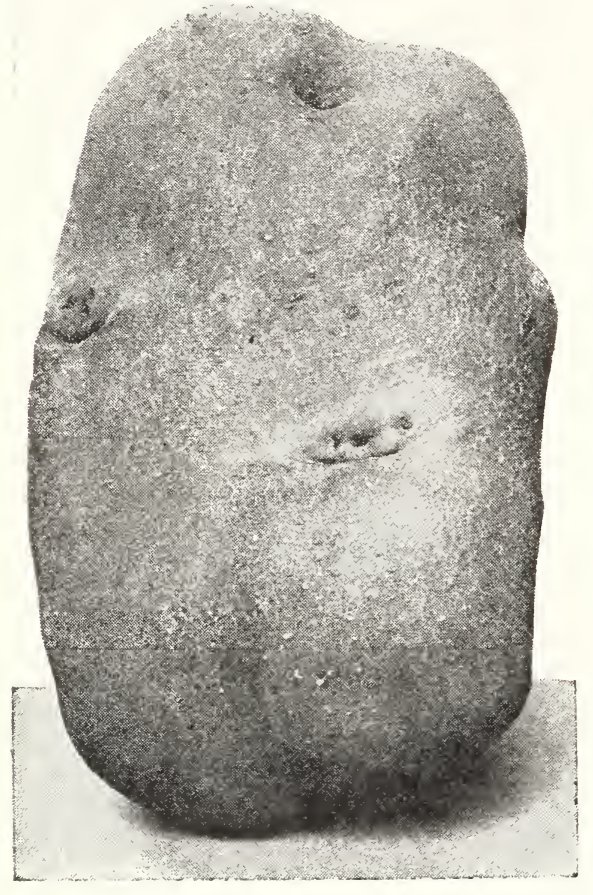

Early Ohio

Write for Prices on Quantity lots. Prices Subject to Market Fluctuations.
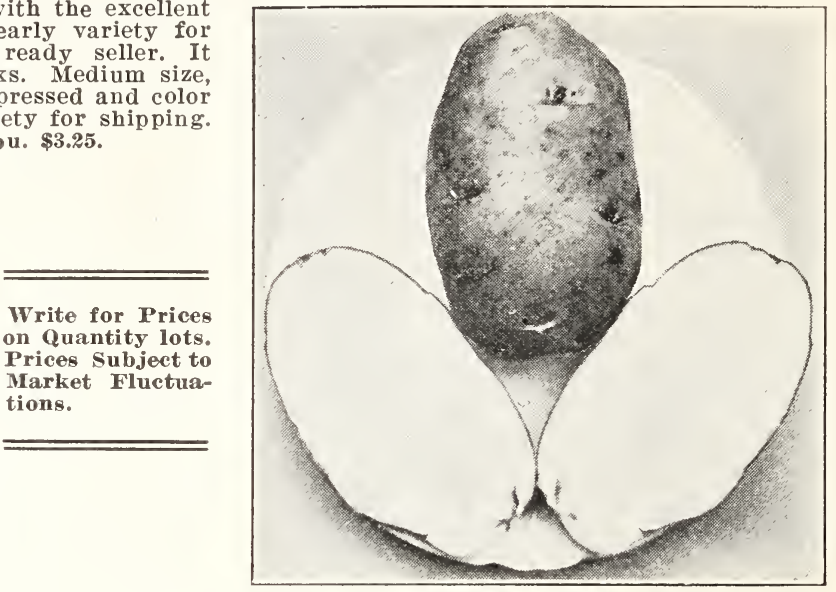

Early Red Triumph

EARLY OHIO-Skin light pink or flesh color: flesh pure white. Potatoes all run good marketable size, very few small ones and the shape is so even they sell on sight in the market. Buyers know of the excellent quality, and housewives find there is no waste in peeling. Parcel Post not prepaid. 15 1bs. \$1.00; 60 lb. bu. \$3.25.

IRISII COBBLER-One of the most popular of the early varieties. Resembles the Triumph in shape. Its excellent quality, together with its cream-white color, makes it fine for the best trade. It is a vigorous grower, a good keeper and ripens uniformly. Parcel Post not prepaid. $15 \mathrm{lbs}$. $\$ 1.00 ; 601 \mathrm{lb}$. bu. \$3.25.

\section{Peppers}

PALMER'S EARLY GIANT PEPPER-This remarkable strain was developed by one of the leading gardeners in St. Louis County, whose peppers have always commanded the highest price on the local market. The plants bear abundantly of rich scarlet fruit, having a heavy texture. Palmer's Early Giant Pepper combines all the qualities of large size, mild flavor and extreme earliness. We highly recommend this superior strain for long distance shipping. Parcel Post Paid. Pkt. 10c; oz. 75c; $1 / 4$ 1b. $\$ 2.50 ; 1$ b. $\$ 8.00$.

CHINESE GIANT-Very large size. Fruit is mild and sweet. Parcel Post Paid. Pkt. 10e; oz. 40e; $1 / 4$ lb. $\$ 1.25$.

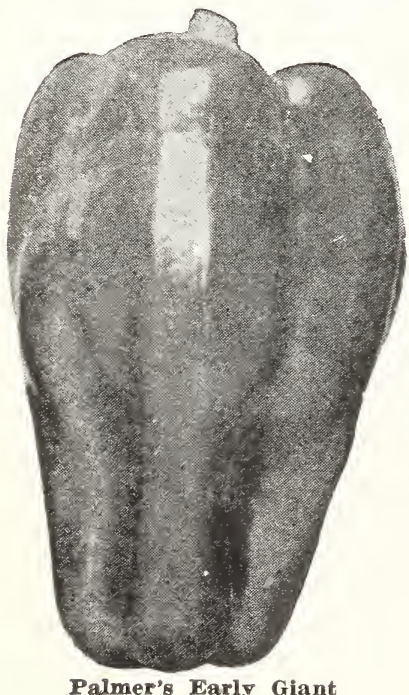

Palmer's Early Giant

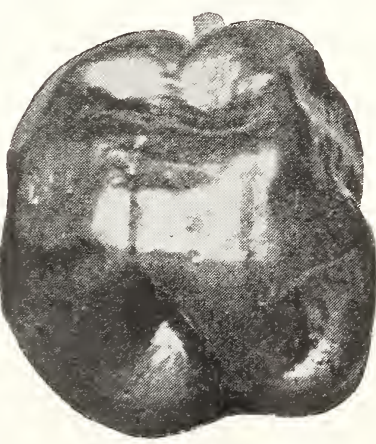

Chinese Giant

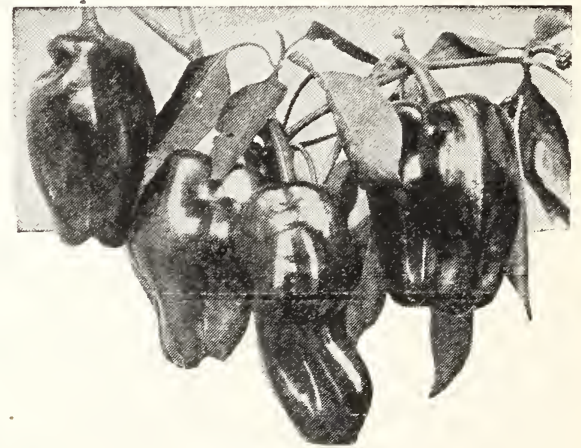

Ruby King

LONG RED CAYENNE-Bears long slender pods, bright red when ripe. Parcel Post Pail. Pkt. 10c; oz. 40c; 1/4 1b. \$1.25.

PIMIENTO PEPPER-A delicious variety, most all meat. Very mild. Parcel Post Paid. Pkt. 10c; oz. 40e; 1/4 1b. \$1.25.

SIVEET MOUNTAIN-Large, regular and of mild flavor; one of the best for pickling. Parcel Post Paid. Pkt. 10c; oz. 40c: $1 / 4$ 1b. \$1.25.

BELL OR BULL NOSE-A large early sort, of mild flavor. Fruits are large. Parcel Post Paid. Pkt. 10c; oz. 40c; 1/4 1b. \$1.25.

RUBY KING--A fine variety, very large and attractive. Fruits are 4 to 5 inches long, bright red when ripe. Parcel Post Paid. Pkt. 10c; oz, 40c; $1 / 4$ 1b. $\$ 1.25$. 


\section{Pumpkins}

CONNECTICUT FIELD-Grown for stock, very productive, uniform type. Parcel Post Paid. Pkt. 10c; oz. 15e; 1/4 1b. 30c; 1 1b. 90c.

Golden Cushaw-Fine golden color. Parcel Post Paid. Pkt. $10 \mathrm{c} ; 0 z .15 \mathrm{c} ; 1 / 4 \mathrm{lb} .30 \mathrm{c} ; 1 \mathrm{~b} .90 \mathrm{c}$.

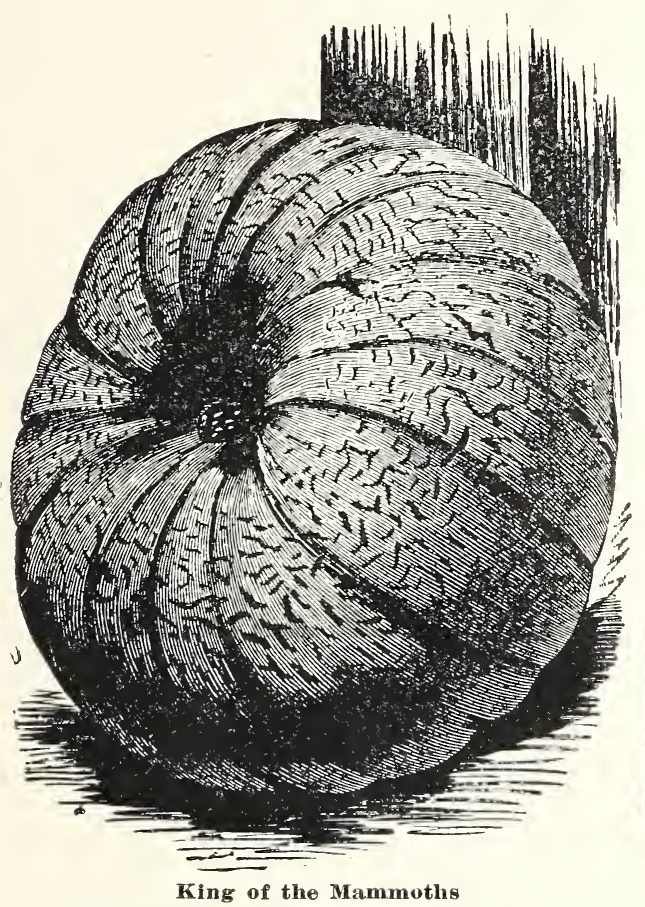

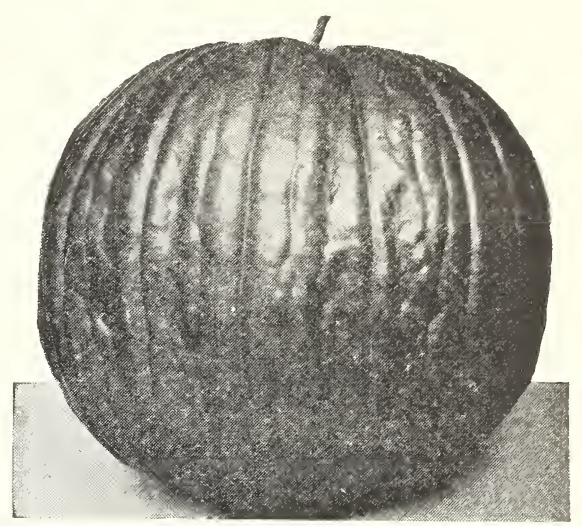

Connecticut Field

LARGE CHEESE or KENTUCKY FIET-Flat:one of the best varieties for family use; good keeper. Parcel Post Paid. Pkt. 10c; oz. 15e; 1/4 1b. 25e; 1b. 75e.

KING OF THE MAMMOTHS-Grows to an enormous size, 150 to 275 pounds; fine for exhibition. Parcel Post Paid. Pkt. 10c; oz. 15e; $1 / 4$ lb. 30c; $1 \mathrm{~b} . \$ 1.00$.

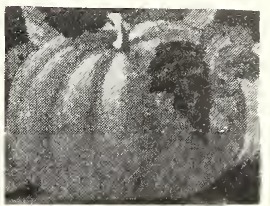

Sweet or Sugar

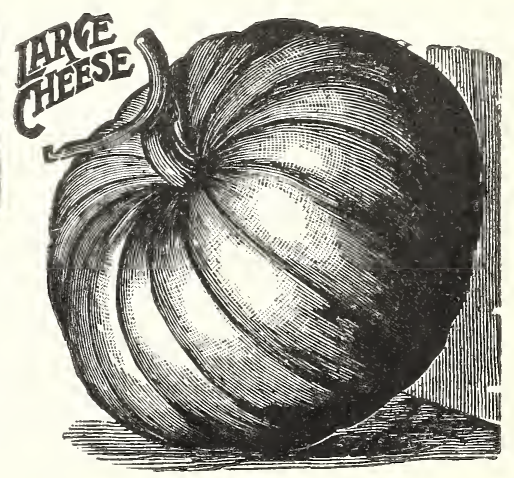

Large Cheese or Kentucky Field

MAMMOTH TOURS-A very large French variety. The large seeds are fine for eating. Parcel Post. Pkt. 10c; 0z. 20c; 1/4 1b. 50c; 1b. \$1.50.

JAPANESE PIE-Fine for pies, very prolific and a good keeper. Parcel Post Paid. Pkt. 10c; oz. 15e; $1 / 4$ 1b. 40c; $1 \mathrm{~b} . \$ 1.00$.

SWEET or SUGAR-Fine grained, sweet and prolific; small yellow best for pies. Parcel Post Paid. Pkt. 10c; 0z. 15e; 1/4 1b. 90c.

TENNESSEE SWEET POTATO-Bell shaped; thick, white flesh, fine for pies. Parcel Post Paid. Pkt. 10c; oz. 15c; $1 / 41 \mathrm{lb} .30 \mathrm{c} ; 1 \mathrm{~b} .90 \mathrm{c}$.

STRIPED CUSHAW-Medium size, crookneck, very productive. Parcel Post Paid. Pkt. 10c; oz. 15e; 1/4 1 . 35c; $1 \mathrm{~b}$. $\$ 1.00$.

White Cushaw-Fine white color. Parcel Post Paid. Pkt. 10c; oz. 15e; 1/4 lb. 35e; 1b. \$1.00.

\section{Rhubarb Seed}

CULTURE-Sow the seed in cold frame in the spring and as soon as the plants are large enough to transplant in rows $1 \mathrm{ft}$. apart each way and cultivate. The following spring plant out in rows 4 feet apart each way and each spring work into the soil a liberal supply of decomposed stable manure. Rhubarb roots are set out and cultivated as the above and this method gives edible rhubarb in a very short time.

Ounce of the seed will sow 75 feet of row.

MAMMoth-Very large, but good quality. Parcel Post Paid. Pkt. 10e; oz. 20e; 1/4 1b. 50e; 1b. \$1.50.

VICTORIA-Very fine in quality, but small. Parcel Post Paid. Pkt. 10c; oz. 20e; 1/4 1b. 50c; 1 b. $\$ 1.50$.

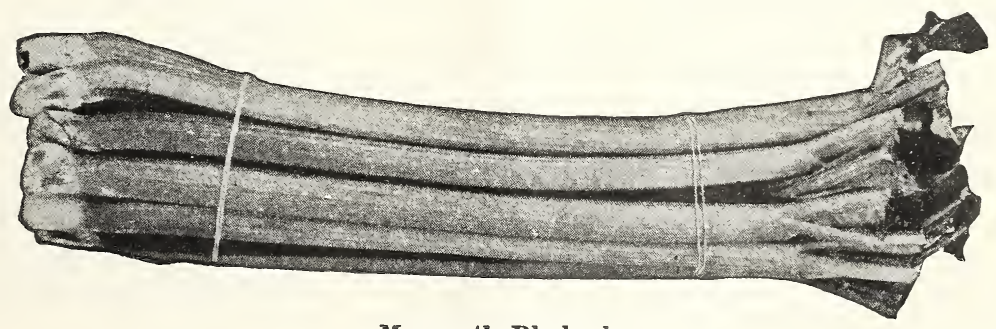

Mammoth Rhubarb 


\section{Radishes}

To be tender and erisp, radishes must be grown quickly, and this requires rich soil and moisture. Begin as early as possible in the spring and sow at intervals of about 10 days in a light, rich, deeply worked soil. For fall and winter sow in August and September. One ounce sows 50 feet.

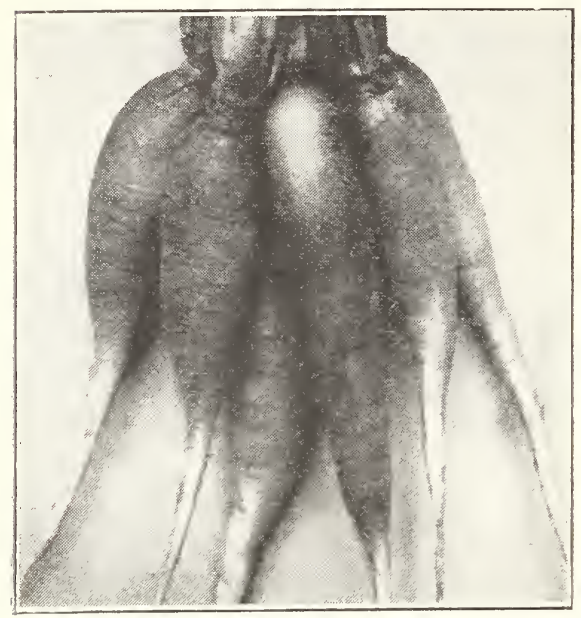

Chartier

EARLY SCARLET TURNIP-A very early, small, round radish; entire radish is of a rich scarlet color. Parcel Post Paid. Pkt. 5c; oz. 10c; $1 / 4$ 1b. 25c; 1b. 65c; 5 lbs. \$3.00.

EARLY SCARLET TURNIP WHITE TIPMarket gardeners' favorite radish outdoor planting. A desirable one for the home garden. Turnip-shaped; handsome scarlet Post Paid. Pkt. 5c; oz. 10c; 1/4 1b. 25e; lb. $75 \mathrm{c} ; 5$ 1bs. $\$ 3.50$.

EARLY LONG SCARLET SHORT TOPEarly, very short top, splendid shape and color. Parcel Post Paid. Pkt. 5e; oz, 10c; 1/4 1b. 25c; 1b. 75c; 5 1bs, $\$ 3.50$.

ST. LOUIS WHITE SUMMER-Of oblong shape, tapering to a point. Flesh pure white, almost transparent, tender and of a delightful pungent taste. Parcel Post Paid. Pkt. 5e; oz. 10e; $1 / 4$ 1b. 30c 1b. 90c; 5 lbs. \$4.

CRIMSON GIANT-A round radish of large size, for an early variety; nearly globeshaped, of crimson-carmine color. Parcel Post Paid. Pkt. 5c; $1 / 4$ 1b. 25c; 1b. 90c; 5 1bs. \$4.00.
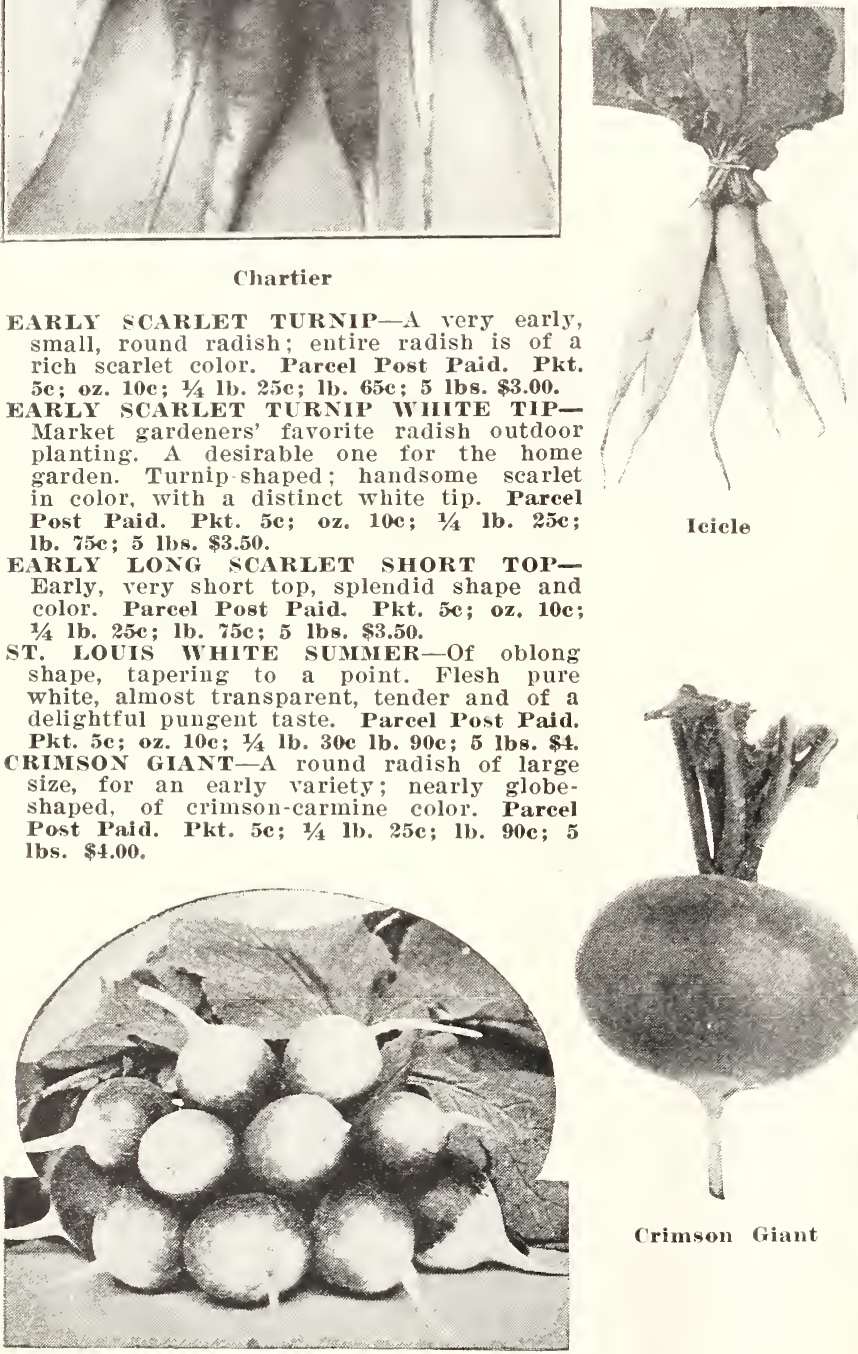

Ieicle

HARTIER or LONG ROSE-White tipped; long red, shading off to fine white tip. Parcel Post Paid. Pkt. 5c; oz. 10c; 1/4 1b. 30c; 1b. 90c.

STRASBLRG-Pure white; oblong; firm, brittle, tender and retains its crispness and withstands severe heat. Parcel Post Paid. Pkt. 5e; oz. 10e; 1/4 1b. 30c; 1b. 90c.

I'HILADELPIIA WHITE BOX-Turnip shape, for forcing or outdoors. Parcel Post Paid. Pkt. 5e; oz, 10e; 1/4 lb. 30c; 1b. $90 \mathrm{c}$.

FARLY SCARLET GLOBE-A very distinct shape. brilliant red color, short leaved, crisp and white, of excellent flavor. Parcel Post Paid. Pkt. 5e; oz. 10c; 1/4 1b. 25e; 1b. 75e; 5 lbs. $\$ 3.50$.

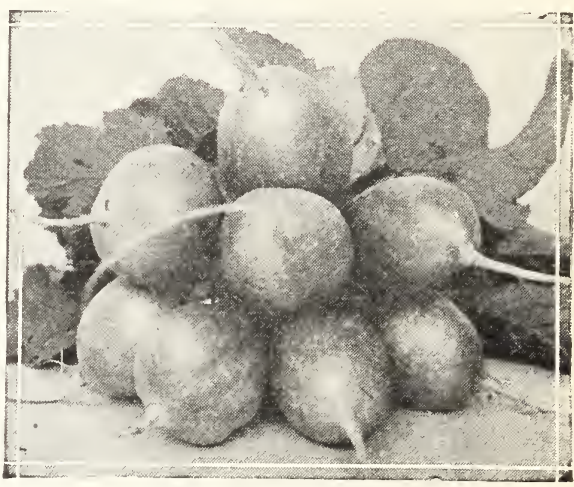

Farly Searlet Globe

FRENCH BREAKEAST - A very popular French variety of very rapid growth, color scarlet, tipped with white, and small in size. Parcel Post Paid. Pkt. 5c; oz. 10e; 1/4 lb. $25 \mathrm{c} ; 1 \mathrm{~b}, 75 \mathrm{c} ; 5$ 1bs. $\$ 3.50$

ICICLE-Long, slender, pure white, the earliest and finest long, white radish. Parcel Post Paid. Pkt. 5e; oz. 10c; 1/4 1b. 25c; lb. 75e; 5 lbs. $\$ 3.50$.

SPIRKLER WHITE TIP-The most attractive bunching radish on the market-the best strain of Scarlet Turnip White Tip Radish, with the white tip well developed, covering

4 the lower half of the radish. Extra early, crisp and tender. Parcel Post Paid. Pkt. 5c; oz. 10c; 1/4 lb. 25c; 1b. 75e; 5 lbs. \$3.50.

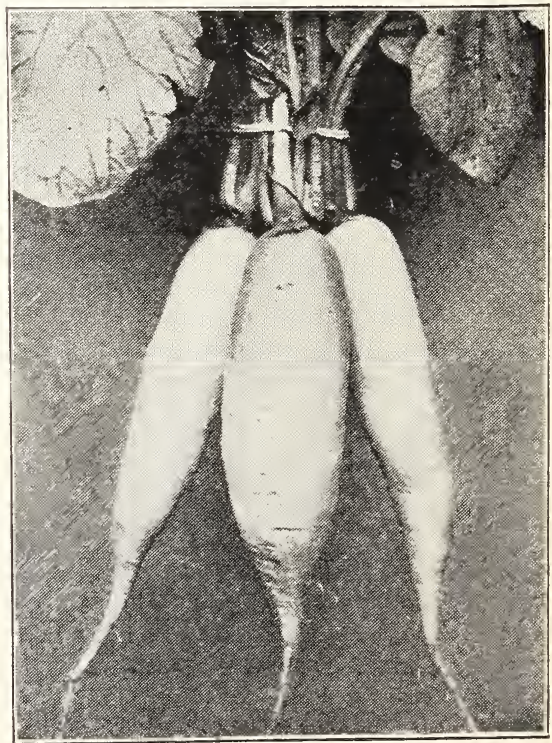

At. Louis White Summer

CHINA ROSE WINTER-One of the very best for fall and winter use, bright rose color, flesh white and firm, superior quality. Parcel Post Paid. Pkt. 5c; oz, 10c; 1/4 1b. 30c; 1b. 90c; 5 lbs. $\$ 3.75$.

ROUND BLACK SPANISH WINTER-This is a large, blackskinned radish; fesh white and firm; a good keeper. Parce Post Paid. Pkt. 5c; oz. 10c; 1/4 1b. 30c; lb. 90c; 5 lbs. \$3.75.

LONG BLACK SPANISH WINTER-Like the above, but the roots are longer and somewhat milder in flavor. Parcel Post Paid. Pkt. 5e; oz. 10c; 1/4 1b. 25e; 1b. 75e; 5 lbs. $\$ 3.50$. 


\section{Squash}

CULTURE-After danger of frost is past, plant in a warm, wellpulverized, rich soil, mixing well-rotted manure with the soil in each hill. Plant 8 or 10 seeds to the hill; the bush varieties 4 to 6 feet apart, the running sorts 8 to 10 feet.

FORDHOOK (Vining)-A small, oblong variety, excellent for summer or winter; fruit 8 inches long, slightly ridged; light yellow in color. Parcel Post Paid. Pkt. 10c; oz. 20c; 1/4 1b. 40e 1b. $\$ 1.00$.

EARLY BUSH SUMMER CROOKNECK.-The best for summer use; fruit bright yellow. Parcel Post Paid. Pkt. 10c; oz. 20c; $1 / 4$ 1b. 40c; $1 \mathrm{~b}$. $\$ 1.00$.

WHITE BUSH SCALLOP OR PATTYPAN-Of a light green color flat, very productive and the earliest to mature. Parcel Post Paid. Pkt. 5e; oz. 15e; 1/4 1b. 35e; 1b. 90c.

YELLOW BUSH SCALLOP-Similar to White Bush except in color. Parcel Post Paid. Pkt. 5e; oz. 15e; 1/4 1b. 35e; 1b. 90c.

LARGE WINTER CROOKNECK-Most cultivated for fall and winter. Parcel Post Paid. Pkt. 10e; oz. 20c; 1/4 1b. 40c; 1b. \$1.00.
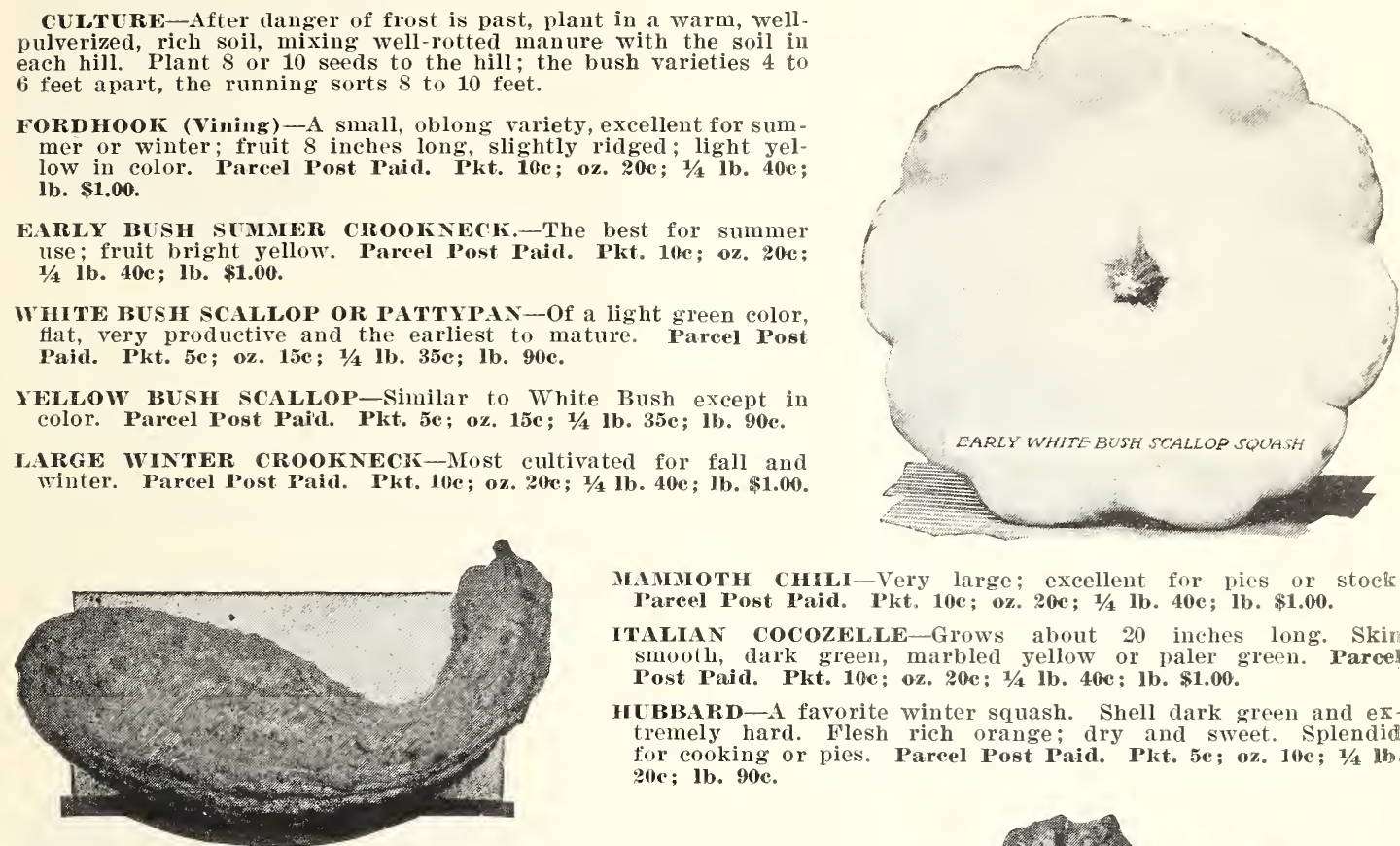

Early Summer Crookneck

\section{Holland Spinach}

BLOOMSDALE CURLED SAVOY-In appearance the leaf is wrinkled in the same way as that of the Savoy Cabbage, hence the name. It produces nearly twice the bulk of crop as the ordinary sort, and fully as hardy. Parcel Post Paid. Pkt. 5e: 2. 10c; 1/4 1b. 20e; 1b, 40c; 5 lbs, \$1.50

CONG SEASON-Of flat spreading but compact growth, this sort is especially noticeable for its short-stemmed, dark green leaves. Stands longer before going to seed than any other sorts. Parcel Post Paid. Pkt. 5e; oz. 10c; 1/4 lb. 20c; lb. 40c; 5 lbs. \$1.50.

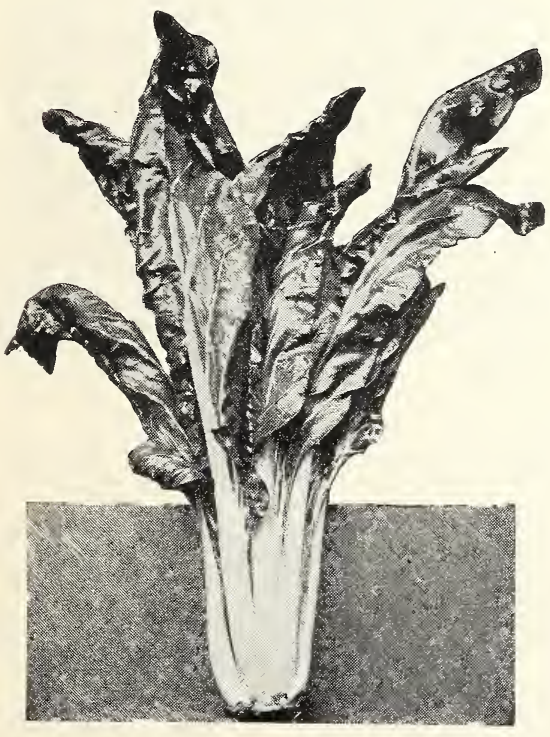

Lucullus Swiss Chard

KING OF DENMARK-The largest growing variety. The glossy dark green foliage is attractively crumpled and thick in texture. The numerous leaves are extra large, broad and rounded. Ready to cut in 48 days. Parcel Post Paid. Pkt. 5e; oz, 10c; $1 / 41 \mathrm{~b} .20 \mathrm{c} ; 1 \mathrm{~b}$. 40c; 5 lbs. $\$ 1.50$.

LONG STANDING-Is especially desirable because of the fact that it is much later in going to seed than the average variety Parcel Post Paid. Pkt. 5e; oz. 10e; $1 / 41 \mathrm{lb} .20 \mathrm{c} ; 1 \mathrm{~b} .40 \mathrm{c} ; 51 \mathrm{bs} . \$ 1.50$

NEW ZEALAND SPINACH-This is not a spinach of the ordinary kind, but a plant of branching growth. One single plant will grow to dimensions of six feet across, producing an abundance of thick, fleshy juicy stems and leaves. Plant in hills 2 feet apart each way 3 or 4 seeds to a hill. Parcel Post Paid. Pkt. $5 c ; 0 z$. 10e; $1 / 4$ 1b. 20e; 1b. 40e; 5 lbs. \$1.50.

\section{Salsify, or Oyster Plant}

MAMMOTH SANDWICH ISLAND-This splendid variety grows to fully double the size of the old sort; is of superior quality and delicate flavor. Parcel Post Paid. Pkt. 10c; oz. 20c; 1/4 lb. $60 \mathrm{c}$; 1b. \$1.95

\section{Swiss Chard, or Silver Beet}

Grown for its leares and stems only. Cook the leaves as you do spinach and the stems like asparagus. The plant is almost perpetual if kept trimmed; also good for poultry greens. Lueullus Swiss Chard is the best variety. Parcel Post Paid. Pkt. 5e: oz. 10c; $1 / 41$ b. 25e; 1b. 60c. 


\section{Tomatoes}

MARGLOBE-The newest and best Tomato. Resists Nail Head Rust and Fusar ium Wilt. Produces a heavy crop of highest quality fruit in 136 days. Canners are especially pleased with this new variety. Parcel Post Paid. Pkt. 25c; oz. $85 \mathrm{c} ; 1 / 4$ lb. $\$ 1.50 ; 1$ b. $\$ 14.00$.

GULF STATE MARKET-One of the finest early globe shaped tomatoes yet produced. A very vigorous grower and withstands blight exceptionally well. Color deep purple pink, smooth skin, and free from cracks. Parcel Post Paid. Pkt. 10c; 0z. 50c; $1 / 41$ b $\$ 1.35 ; 1 b . \$ 5.00$.

JOHN BAER-An extra early red fruited sort of merit. The fruits are large, near. ly round, smooth and of good quality. Parcel Post Paid. Pkt. 10c; oz. 40c; 1/4 1b. $\$ 1.00 ; 1$ b. $\$ 3.50$.

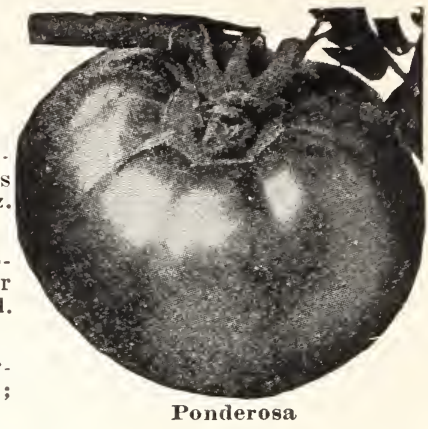

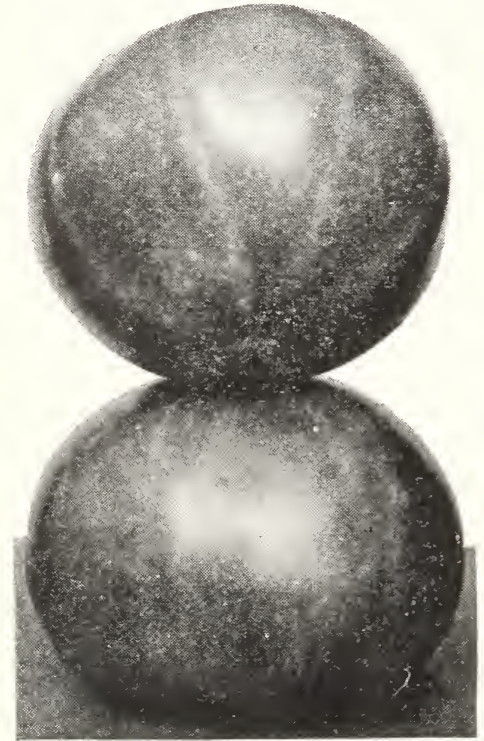

June Pink

TRUCKER'S FAVORITE-A purple fruited sort of excellent quality. Fruits are invariably smooth, solid and the flesh is of finest color through. out. Plants are very thrifty, free from rust or blight, and bear continu. ally until killed by frost. Parcel Post Paid. Pkt. 10c; oz. 45c; 1/4 1b. $\$ 1.25 ; 1 b$. $\$ 4.50$

IATCHLESS-A fine, smooth main crop tomato of rich cardinal red color. with solid flesh of finest quality. Grows to good size. Parcel Post Paid. Pkt. 10c; oz. 40c; $1 / 4$ 1b. $\$ 1.00 ; 1 b . \$ 3.50$.

DWARF CHAMPION-Quite distinct in foliage and habit of growth, being compact and upright; fruits early and resembles Acme in appearance. Parcel Post Paid. Pkt. 10c; oz. 40e; $1 / 4$ 1b. $\$ 1.00 ; 1 b . \$ 3.50$.

PERFECTION (Livingston)-Early, regular productive, red, heavy cropper. Parcel Post Paid. Pkt. 10c; oz. 40c; $1 / 41$ 1b. $\$ 1.00 ; 1 b . \$ 3.50$.

BONNY BEST-An excellent extra early variety,

EARLY ACME-Smooth. solid, purplish pink in color.-Parcel Post Paid. Pkt. 10c; oz. 40c; $1 / 4$ 1b. $\$ 1.00 ; 1 b . \$ 3.50$.

LIVINGSTON's GLOBE-A desirable variety; large, roundish fruits, excellent for slicing. Flesh firm, with few seeds; ripens evenly; has a delicate, agreeable flavor; vines very productive. Parcel Post Paid. Pkt. 10c; oz. 50c; 1/4 1b. \$1.75; 1b. \$6.00.

LIVINGSTON BEAUTY-A productive main crop variety, with large, smooth, solid, purplish-pink fruit. Parcel Post Paid. Plit. 10e; oz. 40c; 1/4 1b. \$1.00; 1b. \$3.50.

J INE PINK-The best extra early purple or pink fruited tomato, excellent for early market. Pkt. 10c; oz. 50c; 1/4 1b. $\$ 1.75 ; 1 b$. $\$ 6.00$.

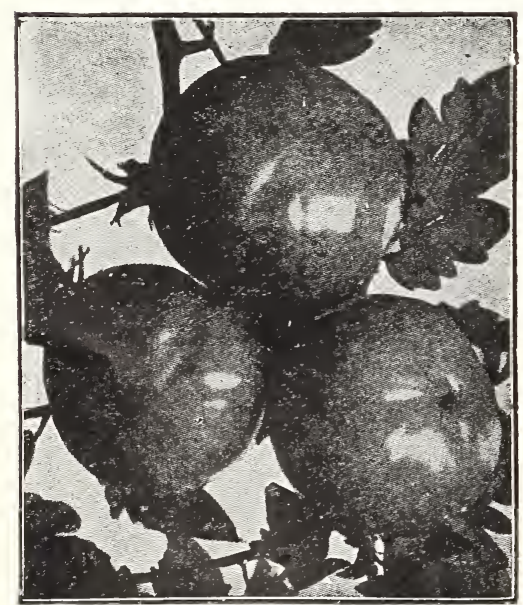

Stone maturing between Earliana and Chalk's Early Jewel. Medium sized, scarlet, smooth, round shape. Parcel Post Paid. Plit. 10c; oz. 40c; $1 / 4$ lb. $\$ 1.00 ; 1 b$. $\$ 3.50$.

EARLIANA-A fine scarlet tomato. Ready for the market several days ahead of any other variety. Ripens uniform$1 y$ and is a good yielder. Parcel Post Paid. Pkt. $10 \mathrm{c} ; \mathrm{oz} .40 \mathrm{c} ; 1 / 4 \mathrm{lb} . \$ 1.00$; 1b. $\$ 3.50$.

PONDEROSA - An exceptionally large, purple fruited tomato, and for home use one of the best; fruit very solid, with few seeds. Parcel Post Paid. Pkt. 10c; oz. $60 c ; 1 / 41 b . \$ 2.00 ; 1 b . \$ 7.00$.

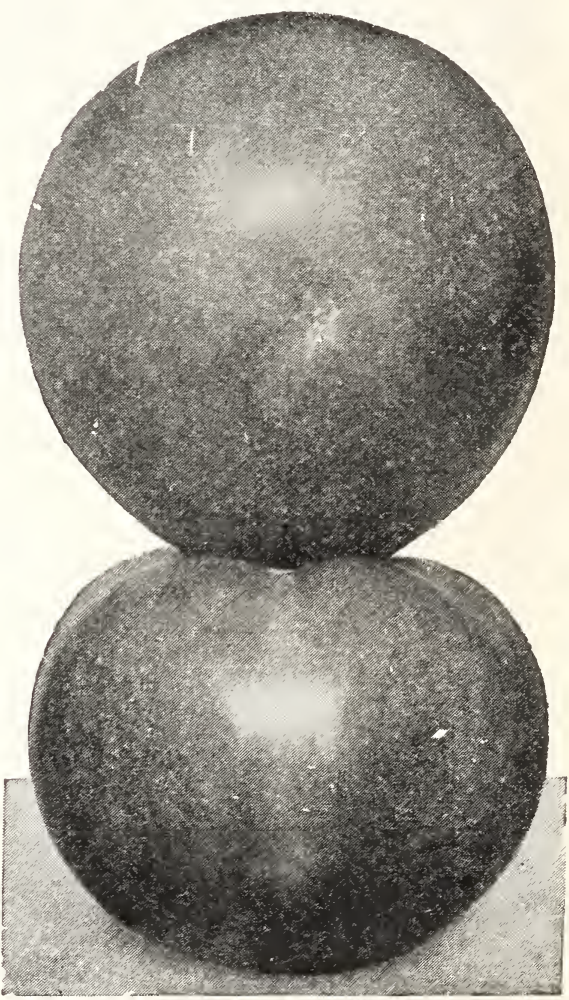

Dwarf Champion
STONE-Especially valuable for late plantings. Very solid and a good shipper; smooth and uniform in growth. Color a desirable red. Fine for canning for its solidity. Parcel Post Paid. Pkt. 10c; oz. 35c; 1/4 1b. $90 \mathrm{c} ; 1 \mathrm{~b}, \$ 3.25$

EARLY DETROIT-The largest and best of the early purplish tomatoes. Fruits very smooth, nearly globe-shaped, firm and of excellent qual. ity. Parcel Post Paid. Pkt. 10c; oz. 40c; 1/4 1b. \$1.25; 1b. \$4.00.

RED ROCK-A selection from Matchless, but is more round or globe shaped than that variety. Parcel Post Paid. Pkt. 10c; oz, 40c; 1/4 lb. $\$ 1.00 ; 1 b . \$ 3.50$.

WHITE'S EXCELSIOR-A main crop, purple variety, large size, heavy and solid, coloring evenly. Parcel Post Paid. Pkt. 10c; oz. 35c; 1/4 1b. $\$ 1.25 ; 1$ b. $\$ 4.50$. 


\section{Turnips}

EXTRA EARLY PURPLE TOP MILAN-A white variety, purple top and strapleaf. This with the White Milan, is the earliest of all turnips. Parcel Post Paid. Pkt. 5e; oz. 10c; 1/4 1b. 25c; 1b. 65c.

EXTRA EARYY WHITE MILAN-The earliest turnip. Tops very small, distinctly strap-leaved and growing very erect. Parcel Post Paid. Pkt. 5e; oz. 15e; 1/4 1b. 35e; 1b. $\$ 1.00$.

EXTRA EARLY WHITE EGG-A quick growing egg shaped, pure white variety. Very sweet, firm and mild. Parcel Post Paid. Pkt. 5e; oz. 10c; 1/4 lb. 25e; 1b. 75e.

LARGE WHITE GLOBE-Excellent for table or salad. A popular variety for winter. Makes large, round white roots, flesh white, solid, sweet and fine grained, maturing in about 75 days Excellent for table or stock; also quite largely used for spring salad. Parcel Post Paid. Pkt. 5c; oz. 10c; 1/4 1b. 25e; 1b. 75c.

COW Hor N-Excellent for table or stock. A long white turnip, 12 to 15 inches in length, $2 \frac{1}{2}$ inches in diameter and growing well above the ground. Of rapid growth, producing large, hell above the 75 days. One of the best and sweetest for home heavy roots in 75 days. One of the best and sweetest for home fertilizer. Parcel Post Paid. Pkt. 5c; oz. 10c; 1/4 1b. 25c; 1b. 65e

MAMMOTH PURPLE TOP WHITE GLOBE-The popular variety for general planting. One of the handsomest and most salable turnips. For home or market it is unsurpassed. It is a large, rapid growing sort, being ready for the table or market in about 65 days, with globular shaped roots. Flesh pure white

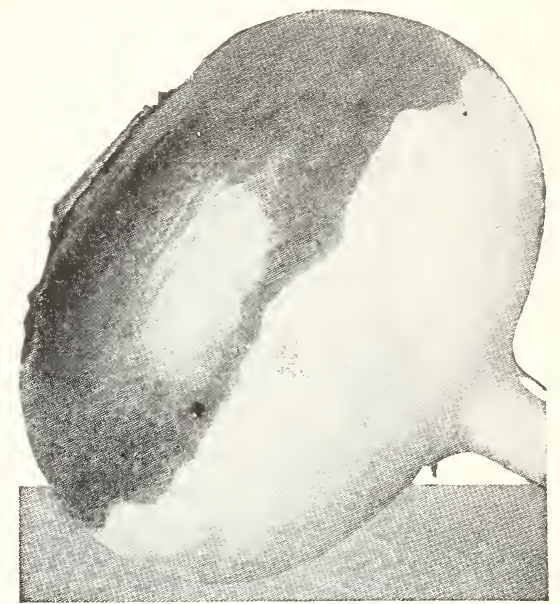

Large Red Top Globe Turnip and the best flavored of all turnips raw or cooked. The skin is white, with a purple top. The most desirable sort. Parcel Post Paid. Pkt. 5e; oz. 10c 1/4. 1b. 25e; 1b. 75c.

LARGE RED TOP GLOBE TURNIP-A perfect globe shape, with bright red or purple top and snow white bottom. It does not taper like other types of the same variety. This is due to the utmost care in selection when growing for seeds. We pride ourselves on this stock. Parcel Post Paid. Pkt. 5e; oz, 10c; $1 / 4.16$. 25e; 16 . 750.

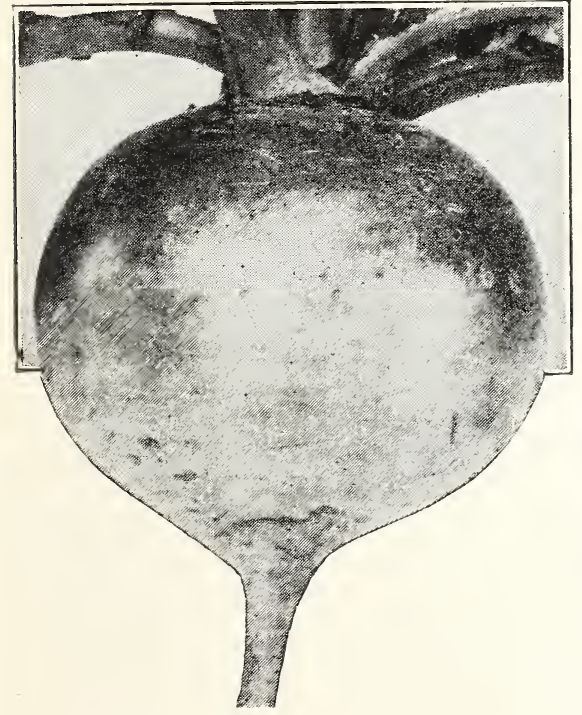

Mammoth Purple Top White Globe

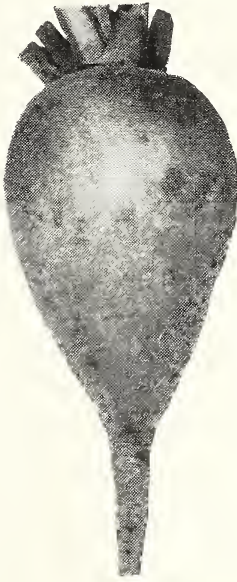

White Egg

YELLOW GLOBE (Stone)-A round, smooth, clear yellow variety, of medium size and good quality. Parcel Post Paid. Pkt. 5c; 0z, 10c; 1/4 1b, 25c; 1b, \%5c.

\section{Rutabaga}

Sow in drills or broadcast in June, July and August.

IMPROVED PURPLE TOP RUTABAGA-The perfect Rutabaga of symmetrical shape and firm flesh. The finest and most profitable of all yellow, purple top Rutabagas, being the hardprot better keepers than most sorts. 1he fesh is of a beautiful yellow color, of the choicest quality, full of nourishment. Excellent for table use and stock feeding. Matures in 95 days. Par-
cel Post Paid. Pkt. 5c; oz. 10c; 2 oz. 15c; 1/4 1b. 20c; 1 ib. roc.

RED OR PURPLE TOP STRAPLEAFFlat, white with purple top. Fine grain ed and tender. Used for early market and table. Parcel Post Paid. Pkt. 5c; oz, 10c; $1 / 4$ 1b. 25c; 1b. 75c.

SEVEN TOP-The old standard popular salad variety, grown extensively for this purpose. Parcel Post Paid. Pkt。 5c; oz. $10 \mathrm{c} ; 1 / 4$ 1b. 25c; $1 \mathrm{~b}$. \%5e.

WHITE FLAT DUTCH STRAPLEAF-An extra early pure white, flat-growing $\nabla 2$ riety Recommended for early maspet. Parcel Post Paid. Pkt. 5e; oz, 100; 1/s 1b. $25 \mathrm{c} ; 1 \mathrm{~b}$. $75 \mathrm{c}$.

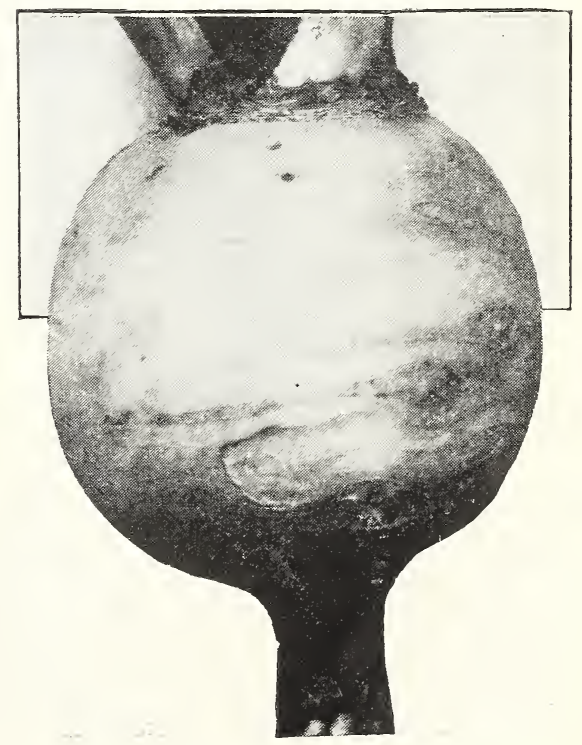

Purple Top Rutabaga 


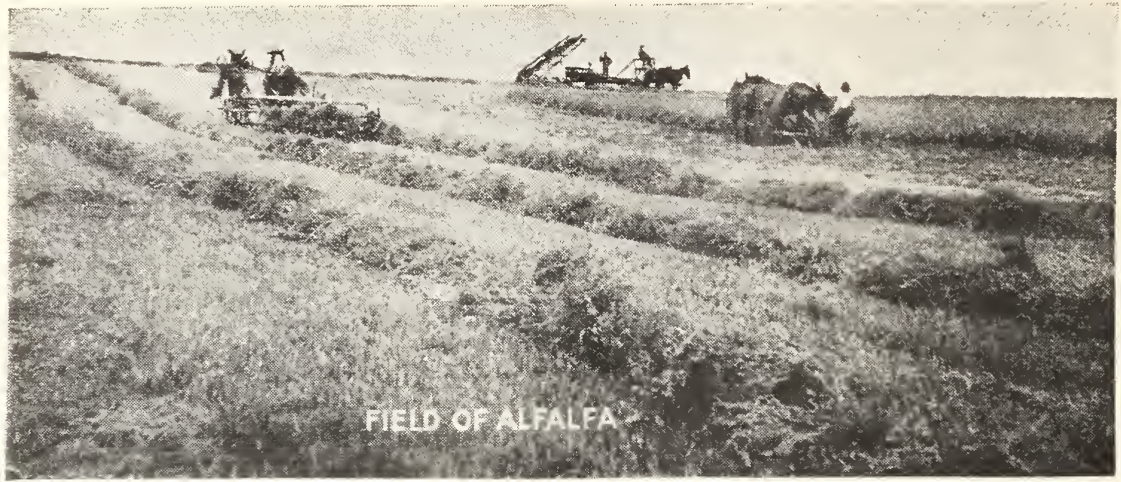

\section{Clovers}

ALFALFA OR LUCERNE CLOVER-The most talked of and most widely planted of all the varieties of clover.

Alfalfa will produce 4 to 5 tons of hay to the acre each year and in money value is worth 45 per cent more than other clovers and 60 per cent more than Timothy hay. It will grow 3 to 4 crops a year and it does not exhaust the soil ; it enriches the soil. Its long branching roots penetrate far down, 15 to 20 feet, and so loosens the subsoil that it is a gigantic subsoiler, resists drought, and gets plant food where other crops would be a failure.

It is said that the feeding value of a ton of alfalfa is equal to a ton of shelled corn. Plant from February to May for Spring, and August to November for Fail at the rate of $30 \mathrm{lbs}$. per acre.

We handle the following brands:

DAKOTA NO. 12-This strain of alfalfa is gaining wide spread popularity throughout the North and Middle West because of its hardiness. Very productive and will resist winter-kill remarkably. If you have been disappointed in raising alfalfa try Dakota No. 12 this year. Parrel Post not prepaid. Lb. 45c; 5 lbs. $\$ 2.00$; 25 lbs. \$7.00. Write for special low prices in larger quantities.

CERTIFIED GRIMM - A strong rooted alfalfa that gives the plant a firm hold on the soil and will withstand the most severe freezes. While the hay production is not as great as the common varieties you are assured of a good stand the first year. It will grow on shallower soil than other sorts. Parcel Post not prepaid. Lb. 55c; 5 lbs. \$2.50; 25 lbs. \$11.25.

GENUNA KANSAS DRY LAND-This alfalfa is nearly as hardy as the Northwestern type and will stand the winters except in high altitudes where severe weathel is found. We recommend it for the Middle West and Southern sections. Parcel Post not prepaid. Lb. 40c: 5 1bs. $\$ 1.75 ; 25$ lbs. $\$ 6.50$

ILSHFE CLOVER-Parcel Post not prepaid. Lb. 60e ; 5 lbs. \$2.75; 25 1bs. \$11.50.

MEDIUM RED CLOVER-The most universally orown throughout the country. On fertile soil and especially where hay is desired, it has only one superior and that is Alfalfa. Sow in the spring and fall, 12 pounds per acre. Parcel Post not prepaid. Lb. 60c; 5 lbs. $\$ 2.75 ; 25$ 1b8. $\$ 11.50$.

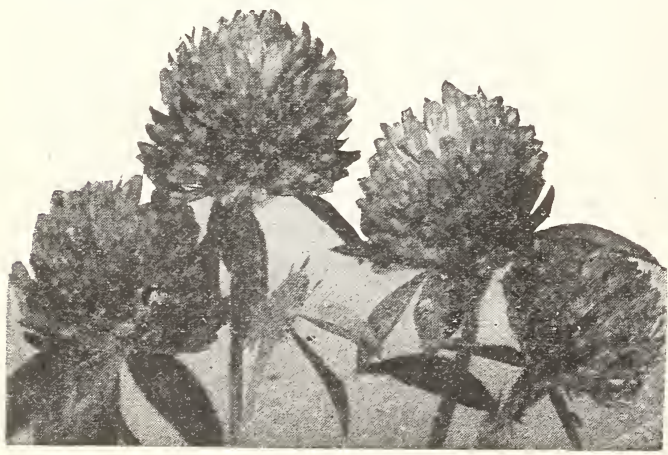

Red Clover
WHITE DETCH CLOVER-This is the common little running clover found in most good pastures. Its chemical analysis shows it to be richer in protein than almost any other legume which we grow for forage. It is of course, too small to grow for hay, but it is invaluable in all pastures. Sow in Spring and Fall. 8 pounds to acre. Parcel Post not prepaid. Lb. 90e; 5 lbs. \$4.00; 10 lbs. \$7.50. Write for quantity prices.

YELLOW BLOSSOM SWEET CLOVER-Parcel Post not prepaid. Lb. $30 \mathrm{c} ; 5$ lbs. $\$ 1.25 ; 25$ lbs. $\$ 5.00$.

IAPANESE CLOVER OR LESPEDEZA-One of the most valuable Southern clovers, growing well on rich or poor soil. On poor land it has a creeping habit; on better quality of land a bush form, making a vigorous plant, growing 12 to 18 inches high. Sow in spring or fall, about 25 pounds per acre. Harrow in to the depth of $11 / 2$ to 2 inches, according to character of soil, then roll or firm the soil in the most convenient way. Makes good grazing. "Well adapted for use as green manure by turning it under; it enriches the soil and prevents "washing" of hill lands. Its abundant long taproots and laterals decaying make the soil porus and leave in it much valuable nitrogenous matter to be used by the following crops. Roots penetrate deeply. enabling the plant to stand severe dry spells, also bring up valuable plant food from the subsoil. Write for prices.

WHITE BLOSSOM SWEET CLOVER-Melilotus Alba or Bokhara. A relative of alfalfa and will make luxuriant growth on soils rich in lime and of insufficient depth for successful growing, of either Alfalfa or Red Clover. Seeds may be sown at the rate of 20 pounds to the acre from September to December or February to April, producing one cutting the first season, but furnishes three cuttings thereafter of from one to two each. Hulled, weight, 60 pounds to bushel. Parcel Post not prepaid. Lb. 30c; 5 lbs. \$1.25; 25 lbs. $\$ 5.00$

CRIMSON CLOVER-For the South. Farmers all through the Middle Atlantic and Southern States are increasing the acreage of Crimson Clover very materially, as they find it one of the best and most satisfactory of early forage and soil-improving crops. Its greatest value is a soil-improver, practical farmers maintaining that a crop of Crimson Clover turned under is equal to a good application of stable manure. Planted during September, October, February and March. Twenty pounds per acre. 60 lbs, to bushel. Parcel Post not prepaid. Lb. 30c; 5 lbs. \$1.25; 25 lbs. $\$ 5.00$.

IRITE FOR SPECIAL LOIV PRICES IN LARGER QUA NTITIES.

\section{Wheat}

RED MAY WHEAT-We have never been able to see where this variety was any earlier and better than the Fultz, although many prefer it to that variety claiming great earliness. It is a standard variety. Beardless. Parcel Post not prepaid. Price, 1b. 100; peck, $\$ 1.00$; bu. 60 lbs., $\$ 3.25$. 


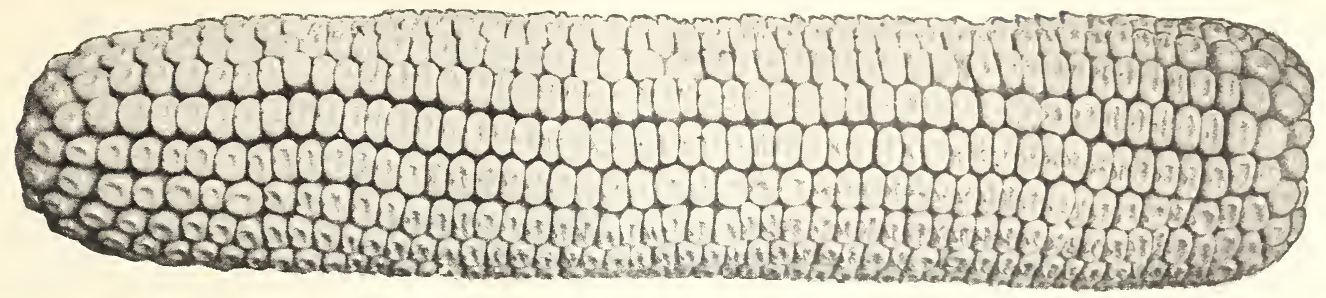

Iowa silvermine

\section{Seed Corn}

We make a specialty of the best Seed Corn, and our volume of business enables us to supply the best stocks at prices that are very reasonable, indeed. As a bushel of corn will plant six to eight acres, there is no excuse for any farmer planting anything but the very best.

IVe have made a study of corn growing. We know good corn when we see it, and we know how to select only the best. For general field crops we urgently recommend our Selected Super Quality Stock. Whatever variety you may select, you may be assured that you can depend on getting the best seed from us.

All quotations are subject to important market changes. Special prices quoted on large amounts.

BOONE COUNTY WHITE-A large eared variety. Is especially adapted to Southern States. Requires from 100 to 120 days to mature. The ears are of large size, well proportioned, well rounded at butt and tip.Parcel Post not Prepaid. 5 1bs. 60e; 15 1bs. $\$ 1.50 ; 25$ 1bs. $\$ 1.75 ; 56$ lbs.. (bu.) $\$ 3.00$.

IOWA SILVER MINE (100 days)-The stalks grow to a height of 7 to 8 feet and set the ears about $31 / 2$ to 4 feet from the ground. The ears measure from 10 to 12 inches in length. They are very uniform in size and shape, 16 to 20 straight rows of deep, pure white kernels on a small cob. It is the heaviest yielder we know, having yielded over 100 bushels to the acre. Seventy pounds of ears will make 62 pounds of corn. It is entirely distinct and will give satisfaction. 5 lbs. 60c; 15 lbs. $\$ 1.50 ; 25$ lbs. $\$ 1.75 ; 56$ lbs. (bu.) $\$ 3.00$. Parcel Post not prepaid.

IELLOW LEAMING-A very early growing corn; matures in about 90 days: always dries out quickly, therefore a desirable variety for early crop. 5 lbs. 60c; 15 lbs. $\$ 1.50 ; 25$ lbs. $\$ 1.75 ; 56$ lbs. (bu). \$3.00. Parcel Post not prepaid.

ST. CHARLES RED COB (110 Days)-The premier ensilage and fodder corn. Has large white ears with red cob and a moderately rough deep grain. Stalks growing very leafy and will produce large quantities for hulling crops of fodder. Being a native of St. Charles County, Missouri, this variety is best adapted to the Middle West and Southern States for hulling corn as well as its chief use for ensilage and fodder. Our St. Charles Red Cob is grown under our personal supervision right here within 25 miles of St. Lonis. Parcel Post not prepaid. 5 lbs. 60c; 15 1bs. \$1.50; 25 1bs. \$1.75; 56c lbs (bu.) Parcel

IOWA GOLD MINE (90 to 110 Days)-Not a very large corn but very good for a medium early variety. It matures in about 95 days, producing medium symmetrical ears of rich golden yellow color. The grain is deep and the cob is small. Our GOLD MINE corn has been bred up and selected from true strains and like all other varieties it is of strong germination. Parcel Post not prepaid. 5 lbs. 60c; 15 lbs. $\$ 1.50$; 25 lbs. $\$ 1.75 ; 56$ lbs. (bu.) $\$ 3.00$.

REID'S YELLOW DENT (100 to 110 Days)-This is the leading outstanding variety of yellow corn grown today. It was originated by Mr. James $\mathrm{L}$. Reid of Illinois several years ago and even the best experts have failed to improve on merit on this corn. It is a deep yellow color and bears deep closely packed grain. REID'S YELLOW DEN'T is particularly adapted to this section of the country and we can recommend it as the best all around field corn. Its leaves and stalks niake a fine ensilage and fodder. Parcel Post not prepaid. 5 lbs. 60c; 15 lbs. $\$ 1.50 ; 25$ 1bs. $\$ 1.75 ; 56$ lbs (bu.) $\$ 3.00$.

WRITE FOR SPECIAL LOW PRICES IN LARGER QUANTITIES.

\section{Oats}

All Prices in this Catalogue are Subject to Market Fluctuations.

Oats should be planted for hay making during early October, though they may be sown as late as the early part of December, also in early Spring, with the expectation of making a fair return. When they are to be cut for hay, it is best to cut when the grain is in milk. While the time of planting is given under each variety, oats are also sown successfully in the early spring.

TEXAS RED RUST PROOF OATS-In the South Atlantic and Gulf States Red Rust Proof Oats have attained a prominent place in farming operations. This is particularly true in the coast region, where other varieties have not proved altogether satisfactory, but where the Red Rust Proof seems to be especially well adapted to the light, sandy soil of that section. They are vigorous growers, robust and productive, and have heavy heads. They are also preferred for sowing on low grounds and on land where other varieties seem inclined to rust. Peck 50c; bu. \$1.50; 5 bu. sack $\$ 6.25$, not prepaid.

WRITE FOR SPECIAL LOW PRICES IN LARGER QUANTITIES.

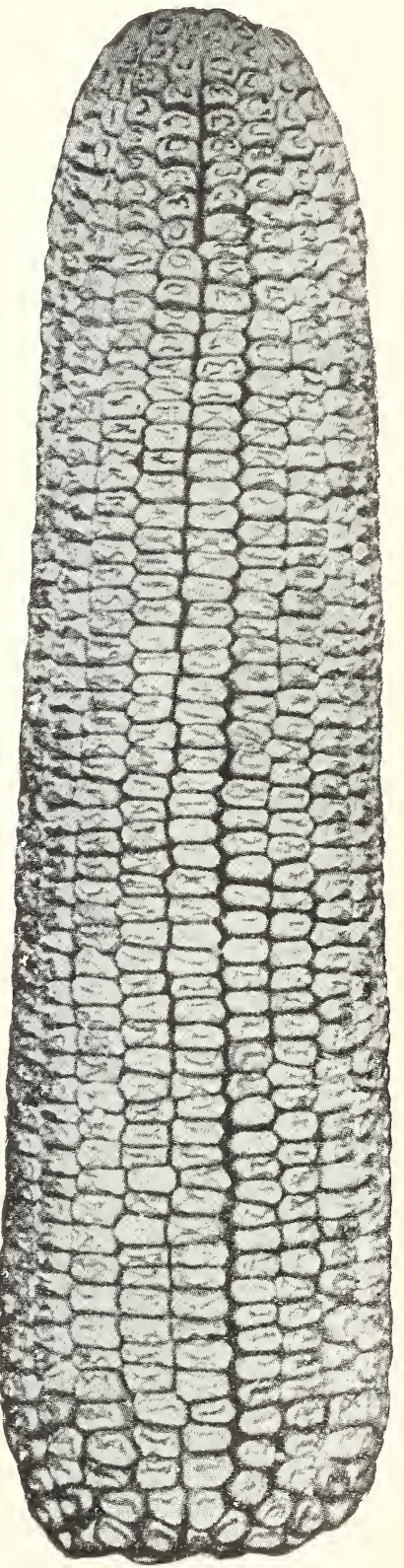

Reid's Yellow Dent 


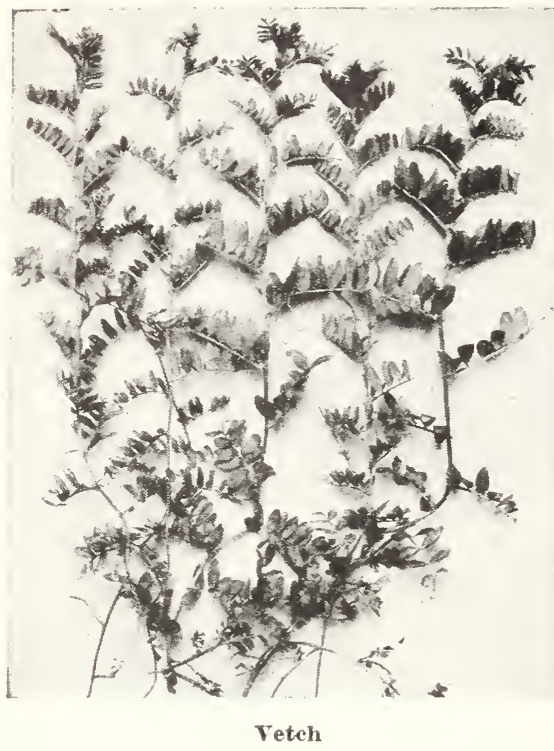

\section{Hairy, Winter or Sand Vetch}

HAIRY, WINTER OR SAND VETCH-Planted from August to November or in early Spring, with small amounts of rye, oats, wheat or barley, for a support after it begins to run, vetch makes a magnificent hay crop in spring, coming in ahead of everything else except thoroughly established fields of alfalfa, and at the same time leaves added fertility to the soil. Crops like Vetch makes possible profitable live stock raising, which in turn means prosperity. Forty pounds per acre during October and Norember. Write for prices.

\section{Seed Barley}

SEED BARLEY-The particular value of Barley is for Winter and Spring grazing. Planted from August to October. Two bushels per acre. 1 lb. 25c; postpaid; $1 / 2$ bushel, $\$ 2.00 ; 48$ lb. bu. $\$ 3.00$, not prepaid.

\section{Sorghums and Millets}

All Prices in this Catalogue are Subject to Market Fluctuations.

GERMAN MILLET-Of all the Millets this is one of the favorites. It makes good hay, and produces heavily. Can be sown from April to June, but the former month is the best time, 50 pounds to the acre for hay. Should be cut when in bloom. Recommended for this climate. 1 lb. $25 c ; 1 / 2$ bu. $\$ 2.50 ; 50$ lb. bu. $\$ 4.50$, not prepaid.

EARLY AMBER SORGHUM-More popular than ever for forage. Relished in its green state or cured, by all stock, on account of sweetness of stalk and leaves. Equals in value any other crop known. Makes good syrup, but as the stalk is smaller than the Orange, that variety is recommended when the intention is to grow for syrup. Twelve and a half pounds of seed will plant an acre. Plant in rows 3 feet apart, 6 to 10 seeds, 12 to 18 inches apart in the row, or drill slightly; can be sown broadcast. $1 / 2$ bushel per acre. Price, 1 lb. 25c; $1 / 2$ bu. $\$ 2.00 ; 50$ lb. bu. $\$ 3.50$, not prepaid.

EARLY ORANGE SORGHUM-Price, 1 b. $25 \mathrm{c} ; 1 / 2$ bu. $\$ 2.00 ; 501 \mathrm{lb}$. bu. $\$ 3.50$, not prepaid.

RED TOP, or SUMAC SORGHUM-1 1b. $25 \mathrm{c} ; 1 / 2 \mathrm{bu} . \$ 2.00 ; 50 \mathrm{lb}$. bu. $\$ 3.50$, not prepaid.

TEXAS SEEDED RIBBON CANE-Grows very similar to the Crookneck variety except that it has a straight head. Is first class to use for ensilage, also for syrup. $15 \mathrm{lbs}$. per acre. $1 \mathbf{1 b}$. $\mathbf{2 5 c}$; $1 / 2 \mathbf{b}$.

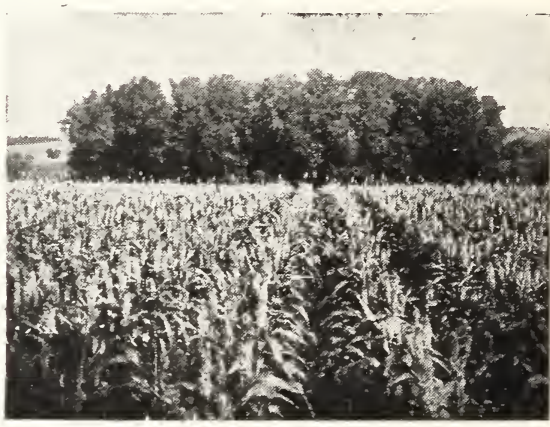

Early Amber Cane $\$ 2.00 ;$ bu. \$3.50. Not prepaid.

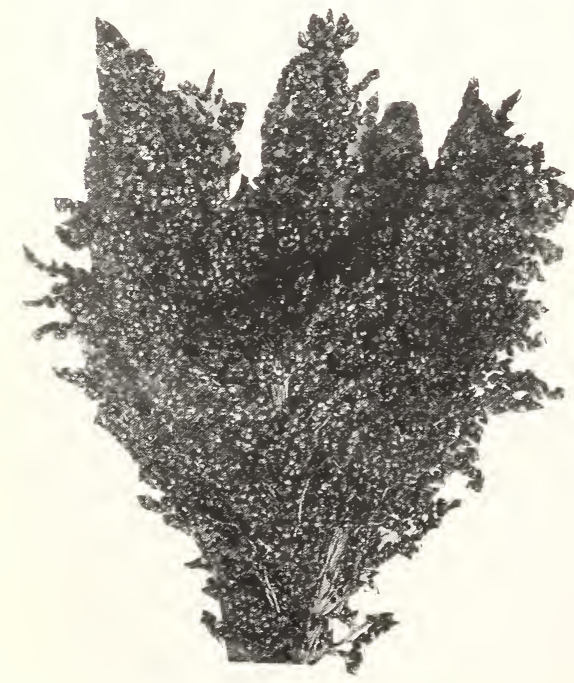

Field of Kaffir Corn

JOHNSON GRASS-1 1b. 40c; 1/2 bu. \$2.75; 25 1b. bu. $\$ 5.00$, not prepaid.

SUDAN GRASS-A live stock food. Grows successfully everywhere. Stock of all kinds eat it readily. Yields more tonnage per acre than any other forage crop. Produces from ten to fifteen thousand pounds of great fodder per acre; suitable for hay or silage. 10 to 15 pounds per acre. 1 lb. 30c; 10 lbs.\$2.00; 100 1bs.\$15.00, not prepaid. Write for quantity prices.

JAPANESE HONEY DRIP CANE-1 1b. $30 \mathrm{c} ; 10$ lbs. $\$ 2.50 ; 501 \mathrm{~b} . \mathrm{bu}$. $\$ 6.00$, not prepaid.

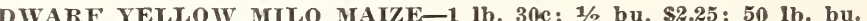
$\$ 4.00$. Not prepaid.

WHITE KAFEIR CORY-Grows 4 to 5 feet high. The stems are very leafy and keep green and brittle, unlike other sorghums, which harden. Makes an excellent fodder, either green or dried. For grain, sow 10 pounds to the acre, in rows 3 feet apart. For fodder, sow from one-half to one bushel, either broadcast or in drills, Very good poultry feed. Sow from March to June. 1 lb. 30c; 1/2 bu. \$2.25; 50 lb. bu. \$4.00, not prepaid.

FETERITA-1 1b. 25c; $1 / 2$ bu. $\$ 2.50 ; 50$ 1b. bu. \$4.75, not prepaid.

EVERGREEN BROOM CORN-There are many farmers who make this a most profitable crop. One acre will produce about $500 \mathrm{cwt}$. of brush and nearly 40 bushels of seed which is equal in value almost to oats for feed. Requires soil similar to corn, same cultiration, but should be planted some later in the season. Put ground in prime condition. We think that more of our farmers should grow Broom Corn for market. It is profitable. Frequently planted in drills $3 \frac{1}{2}$ feet apart, leaving plants 6 inches apart; 20 pounds to an acre. Sow during March and April. 1 lb. 25c; $1 / 2$ bu. $\$ 2.50$; 46 lb. bu. \$4.50. Not prepaid. 


\section{Grass Seeds}

FNGLISH OR PERENNIAL RYE GRASS (LOLIUM Perenne)-Imported English Blue Grass. Height 15 to 24 inches. Considered invaluable for per markably fine foliage, tillers out close to the ground and soon forms a compact sward. After being cut it grows up in a very short time and remains bright and green throughout the season, consequently is well adapted for lawn mixtures to give quick results. Also a good variety for hay, if cut when in blossom, as it is then most nutritious. Sow, if alone, 50 to $60 \mathrm{lbs}$. per acre, $(24 \mathrm{lbs}$. per bushel.) Parcel Post not prepaid. Per 1b. 25c: 10 lbs. \$2.25; 25 lbs. $\$ 5.00$.

ITALIAN RYE GRASS-Lb. 25c; 10 1bs. \$2.25; 25 lbs. \$5.00, not prepaid.

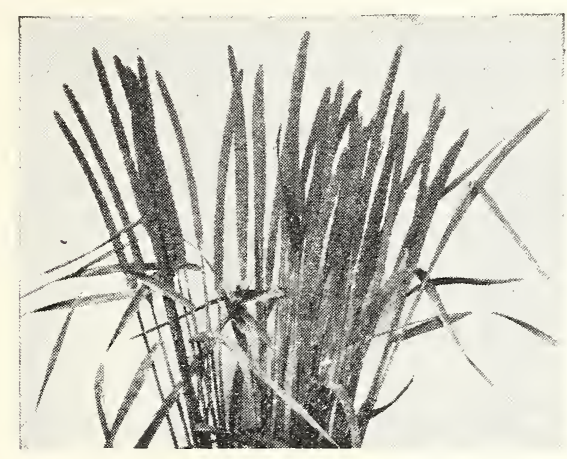

Timothy

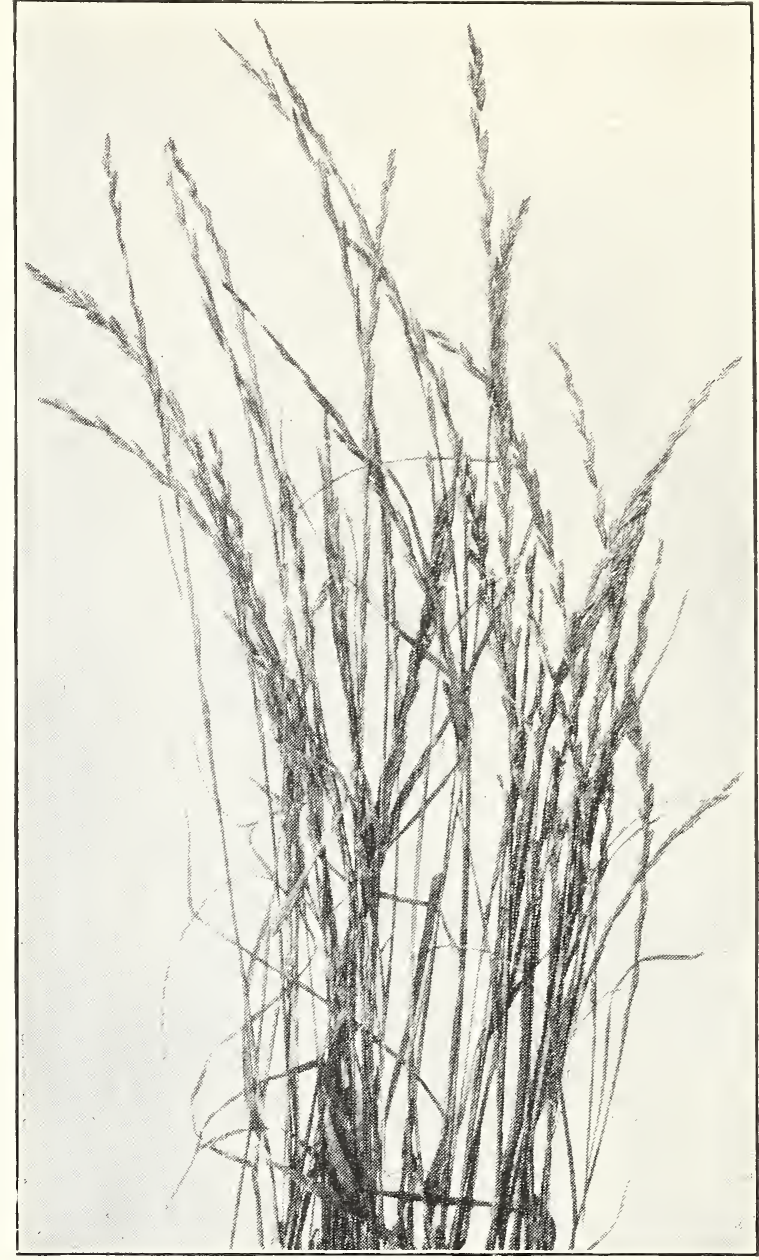

English Rye Grass

TIMOTHY-This is the old standby for hay and pasture. Can be sown alone at the rate of 10 to 12 pounds per acre or with Red Clover or Alsike. Timothy can be seeded with a grain crop either in the spring or Fall and produces a reliable and sure hay crop. We have some fine Timothy new crop and are able to give you the benefit of our very low price for this bright clean seed because we are in the heart of the Timothy growing sec tion. Our Timothy is the cream of crop. Parcel
Post not prepaid. Lb. 20c; 5 lbs. 90c; 10 1bs. $\$ 1.50$.

ORCHARD GRASS-A very vigorous grower, and yields large crops of excellent and nutritious hay, as well as having a special value as a pasture grass, furnishing good grazing from early Spring till Winter. It responds quickly after cutting or grazing. The roots extend to a great depth; it will stand drought better than
most other grasses and is very hardy. It grows in tufts and is therefore best sown with other grasses. It is well suited for shady places, such as orchards and groves. Grows on all kinds of land, but does best on deep, rich sandy loam or clay soils. We have a fine lot of new seed and have a fine lot uf new seed and while the crop was short we can
make very attractive prices, due make very attractive prices, due
to our early purchases. Lb. 30c 100 lbs. \$25.00, not prepaid.

RED TOP or HERD'S GRASS-Red Top is especially adapted to growing on wet soil, having an impervious sub-soil The value of Red Top as a feed is not appreciated by a great many who have never given it a trial. It is one of the very best grasses for pasture, springing up very early and quickly in the Spring, containing its sturdy growth throughout the Summer and Autumn, even resisting the severest droughts. It does better on wet clay soils than on

Orchard Gras

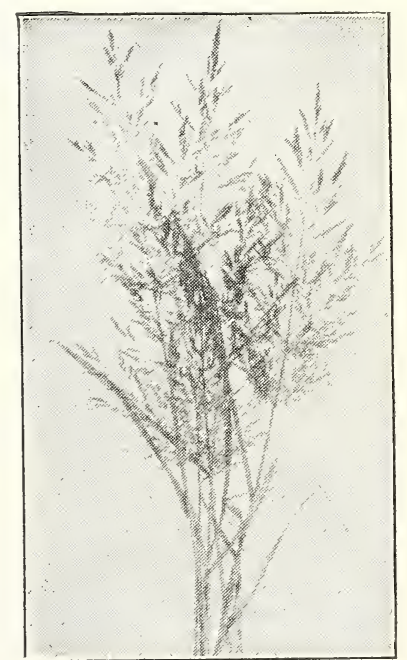

Red Top 


\section{Rape}

DIF AR F-FY RAPE-A splendid winter forage plant. This is ture: can be grazed 6 weeks after planted; use $501 \mathrm{bs}$. per acre. Planted from September to March. Parcel Post not prepaid. Lb. 25e; 10 lbs. \$1.25; 25 lbs. \$3.00.

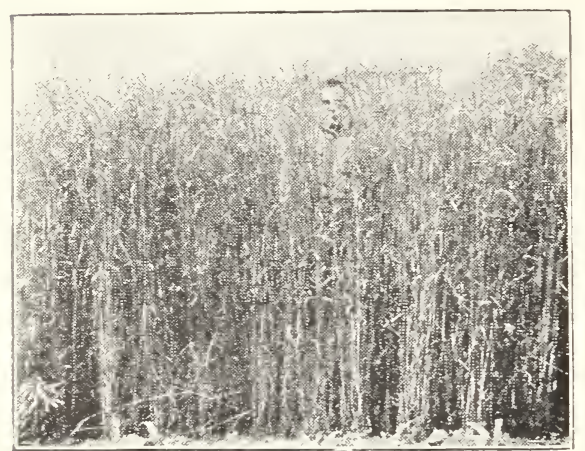

Rye
W R I T E F O R S P E C I A L LOW PRICES IN ILARG-
ER QUANTITIES.

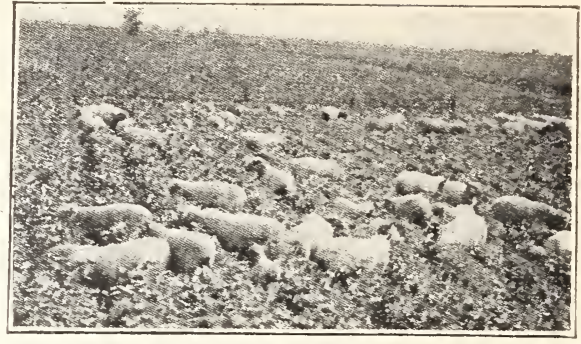

Rape

\section{Rye}

ROSEX RYE-Rosen Rye in comparison with other ryes in the same season has the reputation of yielding 10 bushels more and sometimes 15 bushels more to the acre. Planted from September to December, 11/2 bushels per acre. 56 lbs, per bushel. Parcel Post not prepaid. Lb. 15e; 10 1bs. 75c; 25 lbs. \$1.50

RYE-It stools hearily, can be grazed sereral times and then allowed to go to seed. Cut and fed green; has made as much as ten tons of green food per acre in fire months. It is sown from the midale of August until Norember, and then again in the early spring. The main planting time is in the Fall, howerer, as it is more valuable when sown early. It is a very hardy plant, withstanding all kinds of rery cold weather without serious injury. Sown both broadcast and in drills; $11 / 2$ bushels per acre. The seed should be corered no more than two inches. Parcel Post not prepaid. Lb. 15e; 10 lbs. 75e; 25 1bs. $\$ 1.50$.

\section{Cow Peas}

Write for Prices on Cow Peas as the Market Fluctuates.

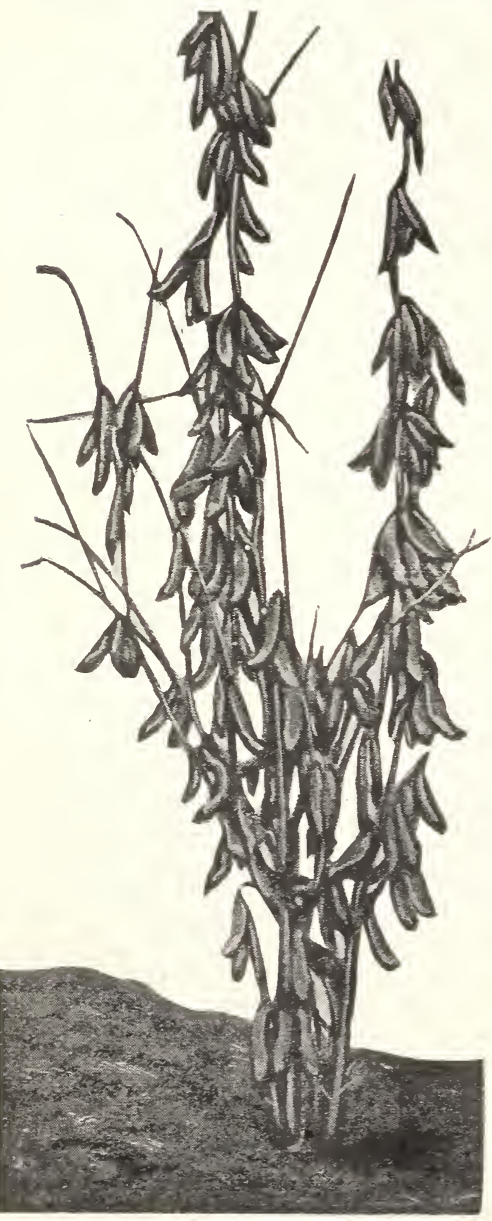

Soy beans
IV H I P P O O R W ILI

- Has brown, speckl-

ed seeds, easily gath-

ered on account of

the upright, bushy growth of the plants. A great farorite on account of its early maturity. Write for Prices.

CLAY-Furnishes large crop of nutritious forage, while the roots enrich the soil. Write for prices.

CANADA FIELD Principally used for pigeon feed. It is a round pearl, planted in Spring and Fall. $11 / 2$ bushels to the acre. Write for Prices.

MIXED PEAS - Every year thousands of come mixed in handl-

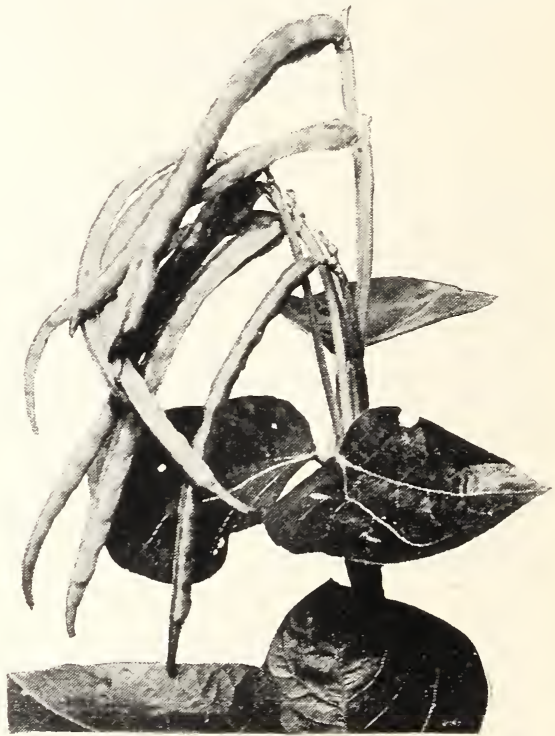

Cow Peas ing and on han for a little less, although they are just as good for forage purposes as the straight varieties. NEW ERA-(The famous Hay Pea)-The new Era Pea is one of the best peas grown. In fact the United States Department of Agriculture states that it is one of the best of our varieties. It is two weeks earlier than Whippoorwill and about one-third smaller. It is a bush pea and stands erect. Write for Prices.

\section{Soy Beans}

We have selected just a few of the most valuable Soy Bean varieties, on which we specialize. Soy Beans are a wonderful legume crop either for hay or pasture, or green manure. Sow 1 bushel per acre.

VIRGINIA (Brown)-An early variety yielding a good tonnage of hay and beans. Particularly suited for planting with corn for silage. Howerer, it is used much as a straight hay crop. Write for prices.

WILSON (Black)-This variety is recommended as wilt resisting and has the advantage of holding the beans in pods for a long time. An early rariety of true merit for hay or grain. Write for prices.

MANCHU (Early Yellow)-By far the most popular of the yellow varieties. Adaptable for all purposes, hay, grain or oil crushing. Write for prices. 


\section{Palmer's Super-Quality Flower Seeds}

IGERATUM-A beautiful, hardy annual, covered with bloom all summer. Blue flowers. Parcel Post Paid. Pkt. 10e; 1/4 0z. 10e.

ALYSSUM-Sweet-scented, hardy annual, blooms early in the spring; a pure white flower, and continues to bloom until late autumn. Parcel Post Paid. Pkt. 5e; $1 / 4$ oz. 15e.

LITTLE GEM-Anumal. Pkt. 10e; 1/4 oz. 25e. Prepaid

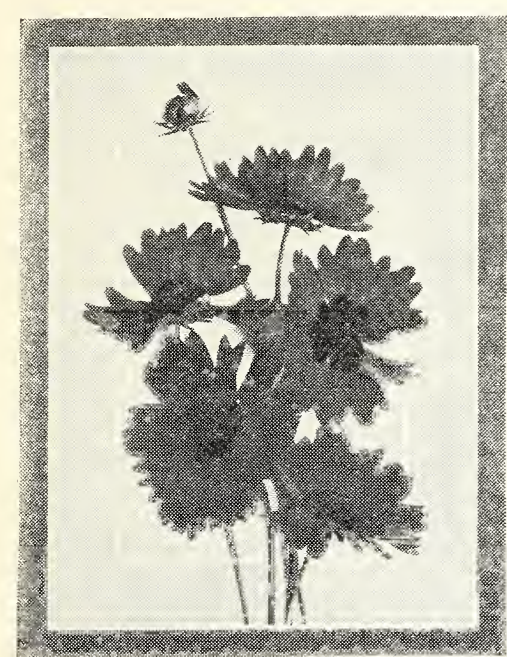

Calliopsis

IBAISAM-Known as Lady Slipper, and Touch-Me Not. The colors range from white to dark purple. Hardy annual. me to two feet high. J'kt.
10e: $1 / 4$ oz. 25e; Parcel Post Paid.

BALLOON VINE-Rapid growing climber; flowers white: 5 feet. Parcel Post Paid. Pkt. 5e

BALSAM PEAR - Large prickly pear - sliaped fruit. Parcel Post Paid. Pkt. 5̃e; oz. 20e.

BALSAM APPLE-Parcel Post Paid. Pkt. 5e; oz. 20e.

CANARY BIRD VINEresembles " mnary hird ed; for baskets, vases, etc. Blooms all summer. Parcel Post Paid. Pkt. 5e.

COBAEA SCANDENS $A$ beatiful climber. Flovering the first season, if sown early in the house or hotbed; bell. shaped, purple tiowers. Parcel Post Paid. Pkt. 10c.

CALLIOPSIS-Showy border plant, flowers bright yellow or rich brown, either self-colored or with these colors and red contrasted. All sorts mixed. Parcel Post Paid. Pkt. 10e; 1/4 oz.

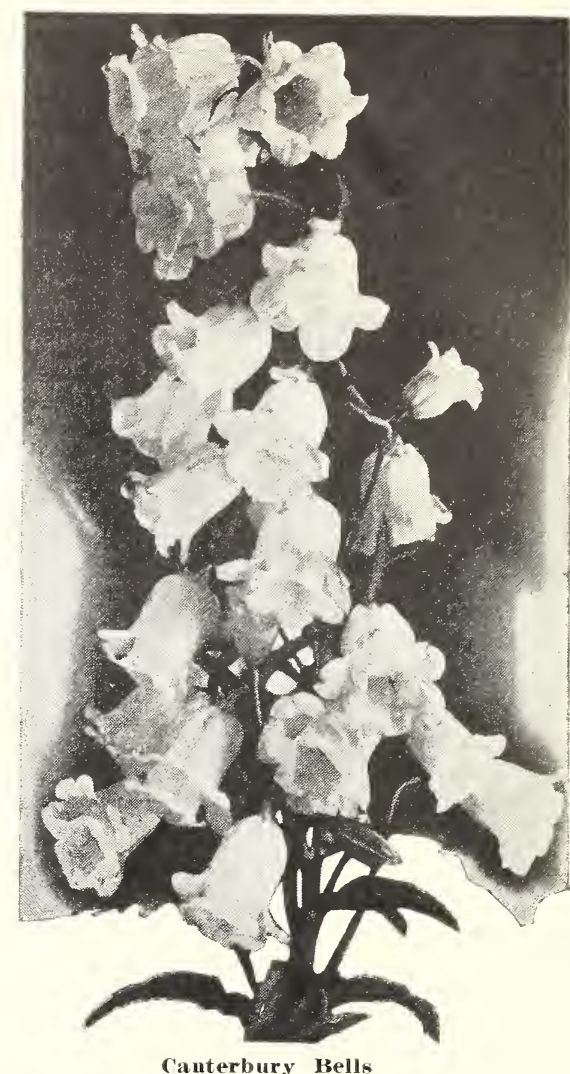
250

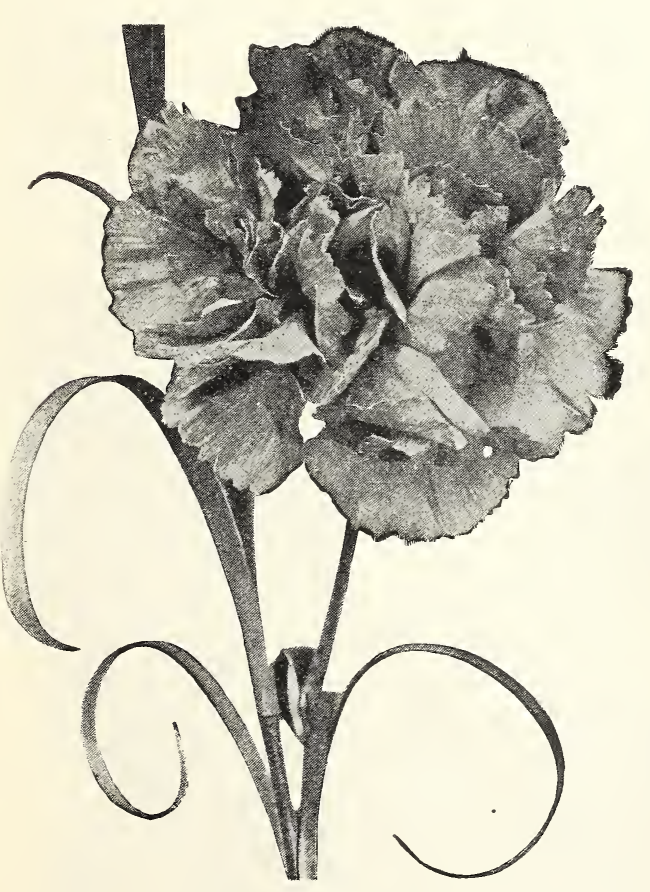

Marguerite Carnation

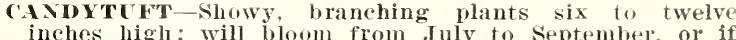
llanted in the fall, from May to July. Mixed rarieties. Parcel Post Paid. Pkt. 10e; oz. 25e.

CASTOR BEAN (Ricius)-Tall, majestic plants for lawns, with leaves of green metallic blue; of very quick growth in rich soil. Parcel Post Paid. Pkt. 5e; oz. 20e.

CANTERISUR IBELLA (Campanula)-Very tine hardy plants profusely covered with extrencely showy bellsliaped flowers, in single, semi-double and double forms in shades of blue, white and rose with some of the blooms 3 inclues in length and 3 inches across of beautiful waxy texture. Single varieties mixed. Parcel Post Paid. Pkt. 10c. Double varieties mixed, pkt. 10\%.

CHLOSI PLCMOSA-Distinct variety of bush form of growth about two feet, branching freely and bearing a profusion of beautifil ball shaped woolly flower heads of intense scarlet. Sometimes called the Wool Flower. flooms all summer until the frost comes. Pkt. 10e. Parcel Post Paid.

C.IRNATION MARGUERITE-Fasily grown from seed; free blooming: flowers bright witl clove-like fragrance some varieties are suited for house plants others do best in the open gromnd. Plant in April. Half hardy perennial. P'kt. 10e; $1 / 4$ oz. $40: 2$. Parcel Post Paid.

CENTAUREA-CYANUs (Bachelor Enttons. Corn Flower) in its improved forms is one of the most attractive of garden flowers. One to two feet high. Single or bouble mixed. hacb-Pkit. 106.-Parcel Post Paid.

COLEI'S OR FOLIAGE PLANT-Our seed mixture is sar efl from plants showing the choirest rolors and best shaped leares. They may be lak:n up in the fall and potted for honse cniture or the seed rin be sown at any time for house plants. They like good soil and plenty of water and there is nothing botter for a bedding plant or for making solid flower beds. Plkt. 15e. Postpaid.

COREOPSIS- Very showy, froe flowering plants, native of this country, fine for borders and beds. Yellow Flowering. Pkt. 10e; 1/4 oz. 25e. Parcel Post Paid.

COLCMIBINE-One of the best of the lardy plants, bearing flowers of exquisite clear blue, white, rose, rellow, purple and striped colors. A fine plant for the shrubbery border or grown as single specimens. Pkt. 10e. Pareel Post Faid. 


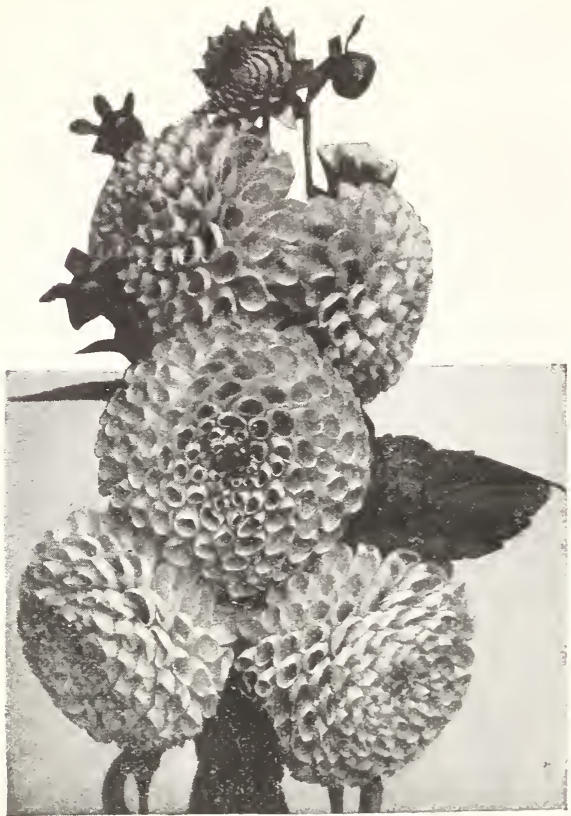

Dahlias

\section{FLOWERS-(Continued)}

Cosmos-A very effective autumn flower. Bush-like plants 3 to 5 feet high, and covered with large single dahlia-like flowers. Iixed. Pkt, 10c. Post Paid.

CIPRESS VINE-A most beautiful climber with delicate, dark green, feather foliage, scarlet blossoms. Tender annual. Mix ed colors. Pkt. 10c. Post Paid.

DHLIA Double Large Flowering-Dahlias can be grown the first season from seed. Fou will get many fine varieties in this way. Our seed is saved from all of the very best of the double flowering and is especially choice. Pkt. 15c. Single Mixed Varieties. There are many very beautiful single flowering dahlias, some of them making a greater display than the double kinds. Pkt. 10c. Post Paid.

E V E R I S TINGSThese old-fashioned flowers are still considered very useful. Many of them have fine colors and are very odd shapes and they are well wort growing. If cut when they come into bloom and hung with heads down and allowed tr dry gradually in a shaded place ther will be straight and perfect in shape and last forever. $\mathrm{O} \mathrm{u} \mathrm{r}$ mixture of seed comprises all the best there is in these wonterful flowers. Pkt. 10c. Post Paid.

FEVERFEW-These are fine plants for bedding, growing about 3 feet high, with large double flowers pure white in color. They are well adapted for bedding or as house plants. Pkt. 10c. Post Paid.

FORGET-ME-NOT-(Myosotis)-A favorite old fashioned flower, bearing in profusion, clusters of blue blossoms. It thrives well in the shade or open border. Hardy perennial. Pkt. 10c. Post Paid.

FoUR o'CLOCK (Marvel of Peru)-The flowers are funnel-shaped and open about four o'clock in the afternoon and remain open all night and generally perish before noon next day; will grow in any soil. Hardy annual, 2 feet high. Pkt. 5e; oz. 20c. Post Paid.

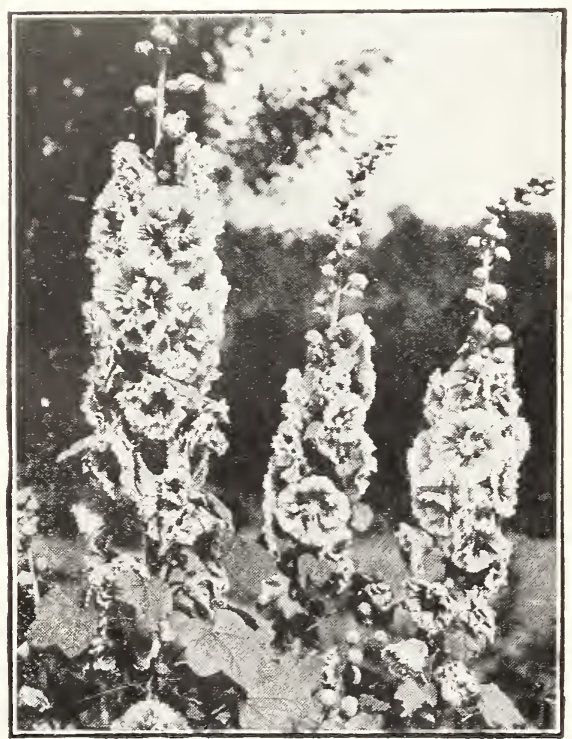

Hollyhocks

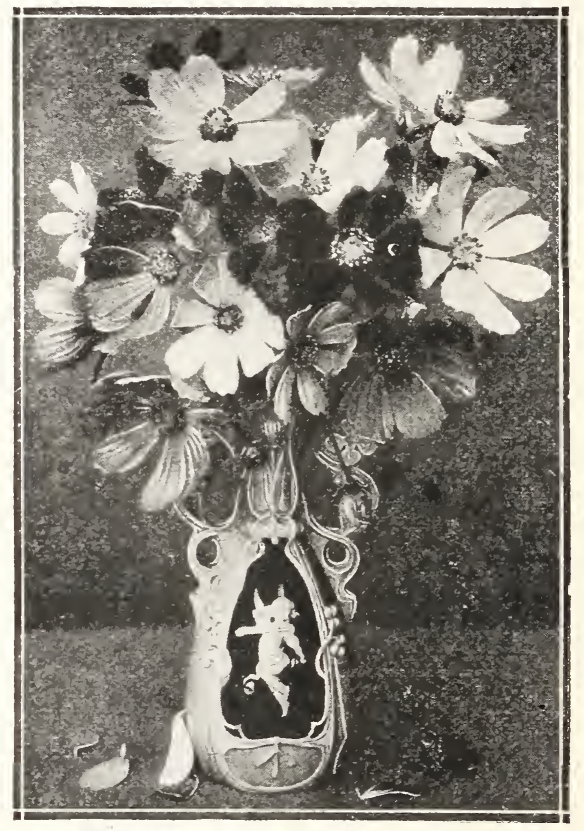

$\operatorname{cosmos}$

FOVGLOVE OR DIGITALIS-Produces long spikes of richly colored flowers that are excellent for cutting. They grow from : to 5 feet and are in many colors in white, pink, purple, yellow and many various shades. Excellent for borders. Pkt. 104. Post Paid.

G.MLCARDIA-single and double mixed. There is nothing more admired for their rich blending of colors than the gaillardia They thrive overywhere and their colors are very gorgeous. The plants grow from 1 to 2 feet high and the double daisy like flowers are very fine for cutting. Pkt. 10c. Post Paid.

GODETIA-Quick growing and profuse flowering hardy annual of showy colors. Easily grown by anyone. Sow seed early in open ground. The equal of an Azalea. Pkt. 10c. Post Paid.

(iYPSOPIIILA - (Baby's Breath) Pretty free flowering, eleaant plants, succeeding in any garden soil. Their misty white panicles of bloom are largely used for mix ing with other cut flowers. Pkt 10c. Post Paid.

HELIOTROPE-Highly valued for the fragrance of their flowers and duration of bloom. Pkt, 10e. Post Paid.

HOLLYHOCK - Everblooming an nual The annual kind bloom the first year from seed. Sown in May they will flower in August, but if started inside and set out early they will bloom in July. They ar free bloomers and continually in bloom throughout the season. Pkt. 10c. Post Paid.

HOLLYHOCK-Double Vixed (Perennial)-Pkt. 10c.

JOB'S TEARS-An olnamental g̉rass known botanically as Coix Lachryma. Grow 2 to 3 feet high, with broad corn-like leaves. Pkt. 5c. Post Paid.

KOCHIA or SUMIER CXPRESS-(Kochia Tricophylla). A highly ornamental annual, having a cypress-like appearance, Its bright a utumn coloring has given it
two other names: "Mexican Fire Plant", and "Burning Bush." Pkt. 10c. Post Paid.

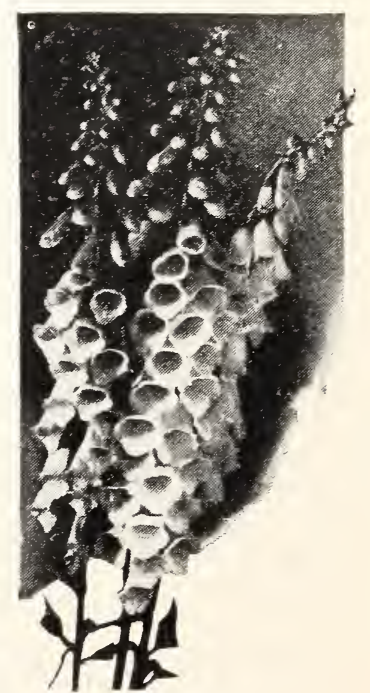

Foxglove 
MIGNONETTE-A well-known hardy annual, producing exceedingly fragrant flowers. Seed sown in autumn will bloom early in the spring; thrive best in cool temperature; 1 foot high. Pkt. 5e; oz. 25e. Post Paid.

MARIGOLD-Old-Fashioned flower blooming in profusion; usually 2 feet high; blooms till frost comes....Pkt. 10e. Post Paid.

MORNING GLORY-Handsome, showy climber, suitable for covering windows, trellis, old stumps, etc., if support be given the vines. Hardy annual; 10 feet high. Pkt. 5e; oz. 25e. Post Paid.

NASTURTIUMS-Giant Climbing-The best of the climbers, as the leaves are the most attractive and the flowers are held out from the foliage better. The foliage is very dark green and the flowers of a great variety of colors measure as much as $3 \frac{1}{2}$ inches across. Pkt. 5e; oz. 15e. Post Paid.

DIVARF or TOM THUMB Nasturtiums are fine for bedding and have large flowers of every known color with a goodly mixing of the darker shades. It is well to plant the mixed, tall and short growing for bedding, as the tall growing hold up the mass of foliage and they make a better effect than if the dwarf kinds only were planted. Pkt. 5e; oz. 15e. Post Paid.

PANSIES-Pansies are now produced in almost infinite variety of form, color and markings. Choice Giant Mixed, all colors. Pkt. 10c. Post Paid.

PHLOX-Mixed will produce all the shades in red, crimson, rose, violet and purple and the best in the striped kinds, There is nothing better than the annual phlox for bedding, as its bright colors cannot be excelled. It is one of the easiest of the annuals to raise and give a wonderful range of colors. Pkt. 10c; 1/4 oz. 40c. Post Paid.

PINKS-(Dianthus)-For beautiful and lasting cut flowers, ease of culture and freedom of bloom, the hardy garden pinks have no superior among annuals. Pkt. 5e; 1/4 oz. 25e. Post Paid.

POPPIES-No other flower produces a more brilliant display of colors during the blooming period.

New Shirley-Pkt. 10c. Post Paid.

Oriental Poppy-Pkt. 10c. Post Paid.

Eschscholtzia (California Poppy)-Pkt. 10c. Post Paid.

PORTULACA or ROSE Moss - There are few flowers in cultivation that make such dazzling display of color in the bright sunshine as a bed of Portulacas. The flowers close in shadow, but are open in sunshine. Pkt. 10c. Post Paid.

PETUNIA-For freedom of bloom, variety of color and effectiveness these have no equals. A little care be stowed upon them, Petunias will produce their hand some, sweet-scented flowers in delicate and gorgeous colors throughout the whole summer. Pkt. 10c. Post Paid.

SMILAX-A climbing plant that holds beaty in its rich dark green shiny foliage. When grown in hanging baskets it droops in a graceful manner that makes it a favorite for that use. Pkt. 10c. Post Paid.

SNAPDRAGON (Antirrhinum) - These tall growing plants have spikes of flowers of very gorgeous colorings, growing to a height of about 2 feet, fine for flower beds or borders and can be cut back in September and potted for winter flowering. All the best colored kinds are produced from our selection of seed. pkt. 10c. Post Paid.

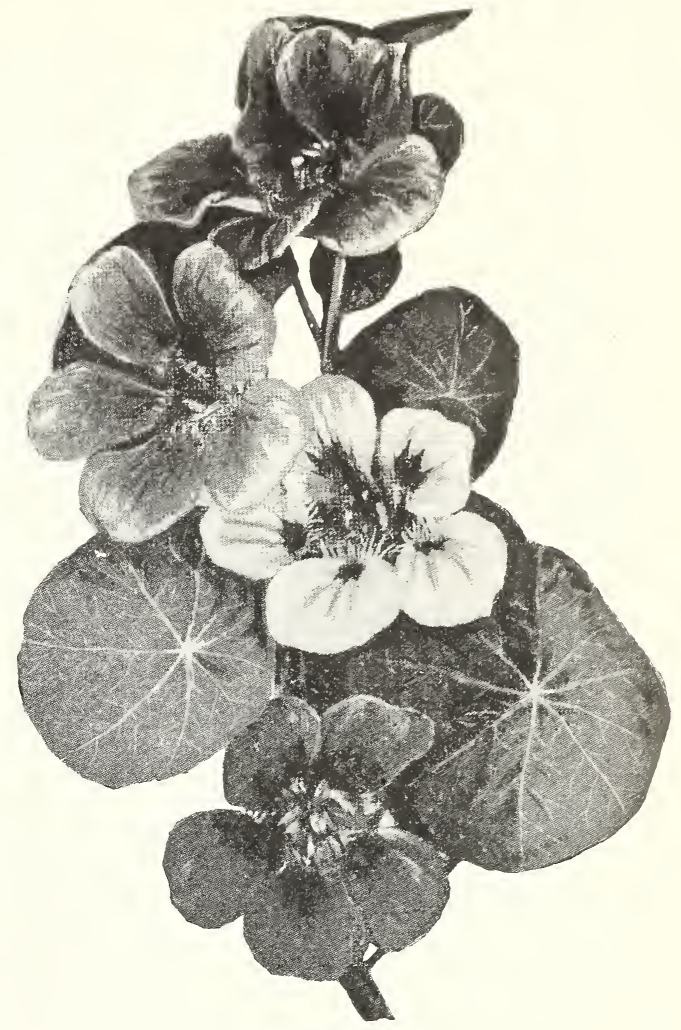

Nasturtiums

SALPIGLossis-Very showy bedding or border plants, with richly-colored, funnel-shaped flowers, which are purple, scarlet, crimson, yellow, buff, blue and almost black; height, 1 foot. Fine mixed sorts. Pkt. 10c. Post Paid.

SALVIA (Scarlet Sage)-The most brilliant colored flowers and extremely useful for bedding. Blooms are of fiery red crimson color, continuing to flower for a long time. Tender perennials; blooms until frost; height 3 feet; Splendens. Pkt. 10c. Post Paid. STOCKS-The Ten Weeks stocks produce immense spikes of perfectly double flowers, measuring from 2 to $21 / 2$ inches in diameter in colors of white, rose, blue, lilac, brown and yellow. They are very fragrant and fine to grow for cut flowers. Our assortment of seed includes the best colored and double kinds. Pkt. 10c. Post Paid.

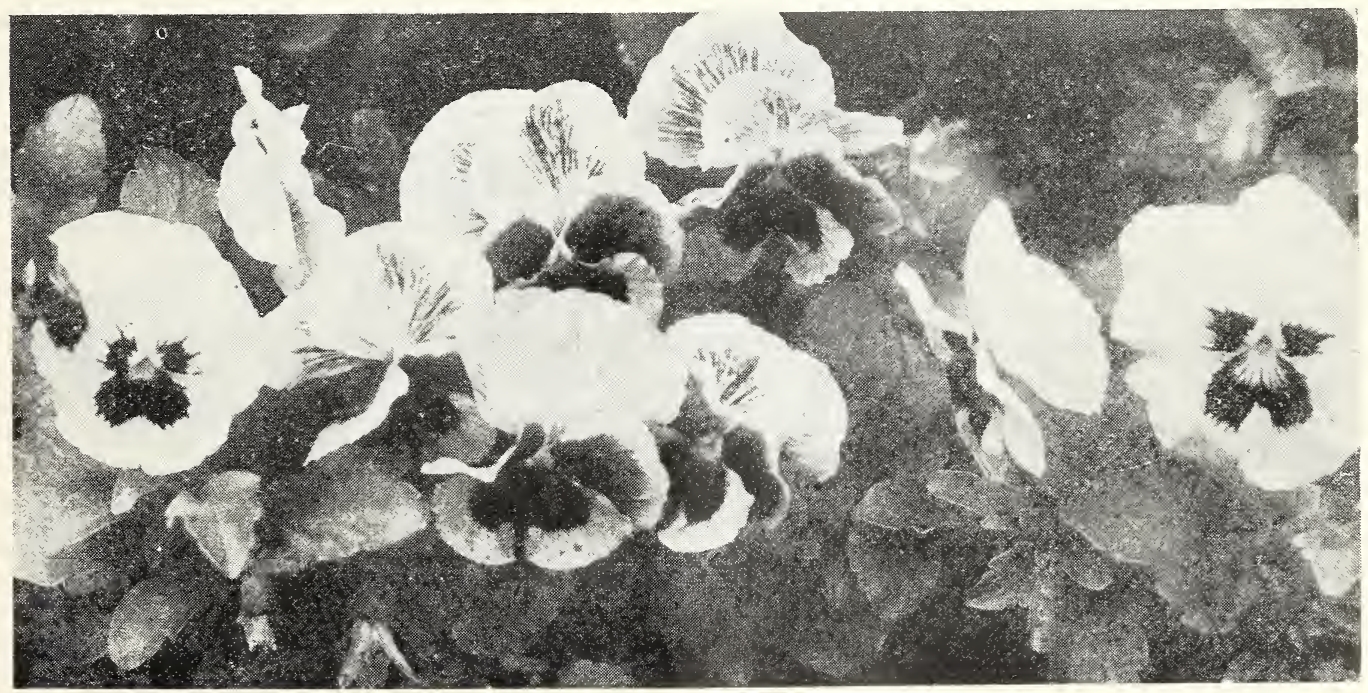

P.INIFS-Giant Trimardeau Mixed-Pkt. 10c; 1/1 oz. 50c. Post Paid. 
FLOWERS-(Continued)

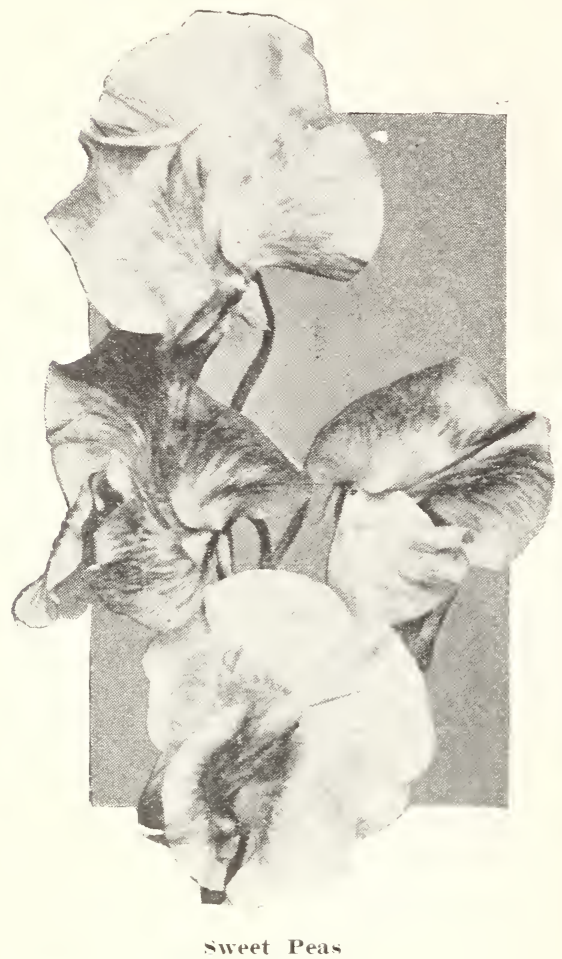

\section{Sweet Peas}

sweet Peas are among the most beautiful of all our hardy annuas. Select a sunny, open place several feet from any building and as far as possible from large trees. Sow as early in the spring as possible Plant in rows and have the rows trenched for planting $t$ to 6 inches deep. In dry weather water freely and keep the 4 to 6 inches deep. In dry weather water freely and keep the
llowers picked closely. If allowed to go to seed plants will stop blooming.

THE SPENCER TYPES are exceptionally large size, with long stems, the wings waved or frilled and the effect remarkably graceful and attractive.

IPPLE BLOSSOM SPENCER-(Rose Spencer)-Standard with primrose wings. Very large; true spencer form. Pkt. 10c; oz. 25c. Post Paid.

PINIK SPENCER-Some of the flowers show striping. It is one of the most attractive varieties ever introduced. Pkt. 10c; oz. 25e. Post. Paid.

WHITE SPENCER-Standard and wings of pure white, beatifully waved and fluted. An especially attractive variety of very large size. Pkt. 10c; oz. 25e. Post Paid.

MRS. HUGH DICKSON (Salmon Pink spencer)-A light on cream backglound, strong growers; throws four flowers to a stem. Pl. $10 \mathrm{c}$; oz. 25e. Post Paid.

FIFRY CROSS-One of the finest new bright reds with cherry orange wings. Pkt, 10e; oz. 25e. Post Paid.

KING EDWARI) VII (Red Spencer)-The best pure red Spencer very large, with especially immense wings. Pkt. 16c; oz. 25c. Post Paicl.

OTHELLO (Maroon spencer)-Of immense size with large drooping mings: rich maroon. Pkt. 10e; oz. 25c. Post Paid.

PAIMER'S ORCHID FLOWERED OR

SPENCER SWEET PEA MIXTURE

stuin of unsurpased quality comprising the best giant flowerinc sorts in a wide range of color from a well known American spertalist. Packets, 1Ce; 0z. 20e; 1/4 1b. 50e; 1b. \$1.75. Post Paid.

PALMER'S BRILIIINT MIXTERE

well blended uixture of the Grandiflora or Large Flowering type whirh will rive excellent results. Packets, 5c; oz. 10c; $1 / 41$ lb. $30 \mathrm{c}$ 1b. 90e. Post Paid.
SUNFOWER-The Dorble Dwarf or Globe of Gold is very double and round in form. They make a stately growth and remain in bloom for a long periot." As a back-ground for the garden they are very useful. Pkt, 10e. Post Paid.

sWEeT WILLIAM-Fine for beds and borders. The seed can be planter in will blossom in the fall. Hardy perennial: 11/2 feet high. Pkt. 10c. Post Paid.

VERBENA - Sown in May, they will bloom in August, but if starter in the house in pots in winter, they will be in bloom sooner. seeds should be soaked in luke warm water before plantins, and care should be taken that the soil be very rich. Pkt. 16c. Post Paid.

WALFTowER-Dwarf Double Branching Mixed-Wallflowers should be better known, as their adaptability for pot culture and out-of-door bedding and the peculiar sweet fragrance of the flowers makes them a great favorite with all that grow them. The oriental colorings of the flowers in their rich reds and yellows is very effective. Pkt, 10c. Post Paid.

CHINESE WOOL FLOWER-This is the finest type of Celosia there is and has made a great sensation wherever grown. They are easily grown and have a plume-like head of dazzling colors in various shades of dark red and purplish-red. Are very valuable for decorative purposes and keep a long time when cut and placed in water. Pkt. 10c. Post Paid.

ZIVXI-Few flowers are more easily srown or bloom more abundantly throughout the season. Sow the seed early and transplant to $1 \frac{1}{2}$ feet apart in good rich soil. Mixed Double, all colors. Pkt. 10. Post Paid.

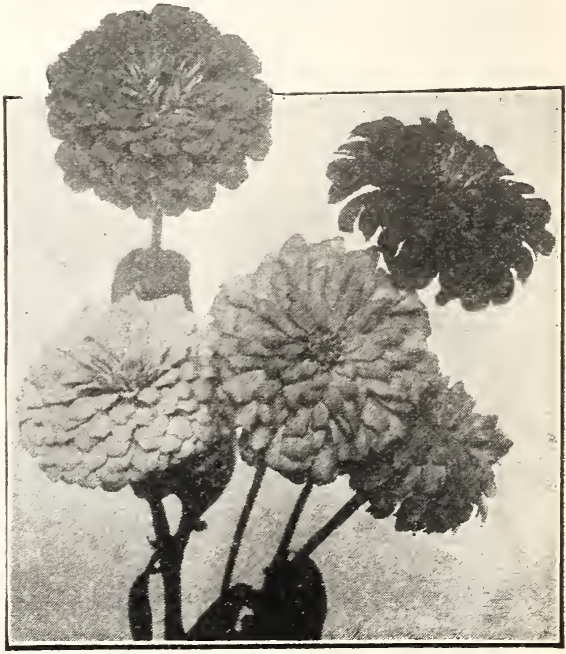

Zinnias

\section{Palmer's Special Offer of Flower Seed Collections}

GIANT SPENCER SWEET PEAS

A DEsIRable Assortuent

10 Packets - 10 Varieties

$50 \mathrm{c}$

RETAIL VALUE $\$ 1.00$
GIANT FLOWERING ZINNIAS

WILL BLOOM ALL SUMMER

6 Packets - Separate Colors $40 c$

RETAIL VALUE 60C

Beautifully illustrated with cultural directions. 


\section{Palmer's Superb Gladiolus}

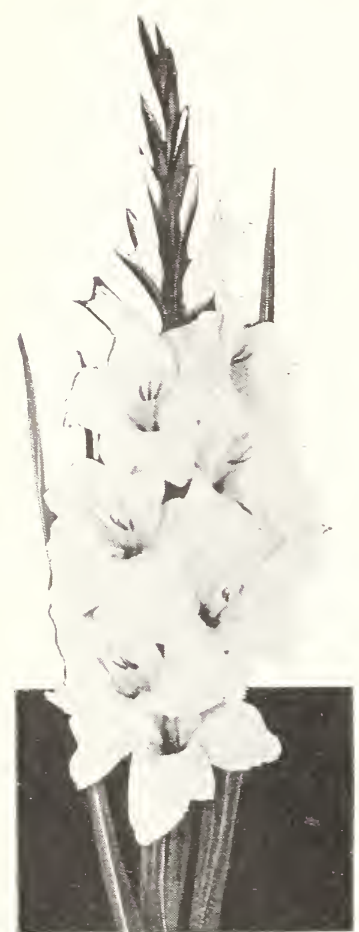

In considering America's beautiful flowers one cannot help but think of Gladiolus as one of the leaders. In them are found the most exquisite shades and contrasts making it one of the most attractive summer flowers. As a border flower or in a bed Gladiolus produces an effect that pleases. Keep in step with the ever increasing appreciation of this marvelous flower by planting a group in your flower garden. You will be amazed at their beauty. Plant 4 to 6 inches apart and 4 inches deep from May to June.

The Best Large Flowering Varieties for Show or Cutting

\section{Superb Large Flowering Gladiolus} INA EBERIUS-Dark velvety purple.....................................................\$0.60 EVELYN IERTLAND-Rosy pink with scarlet blotches...............................60 FLORA-Large golden yellow GRETCHEN ZANG-Lorely soft pink with searlet markings................. .90 HERAD - Pure maure with doen LE MARECHAL FOCH-Large rose pink, very early...................................85 IIRS. FRANCIS IIING-Light scarlet or flame color.....................................60 MRS. FRANK PENDLETON-Salmon pink with deep red blotches in the throat PEA touch of carmine in the throat...................75 PRINCE Of

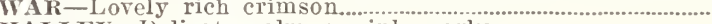
HALLEX-Delicate salmon pink, early SCHWABEN-One of the best yellow sorts

WILLBR INI-Early, delicate pink

TRS. DR. YORTOY-Thite, seft pink and prim

PRIMLLINUS HYBRIDS MIXED--A strain of brilliant and beautiful orchid like flowers produced on strong slender spikes. An ideal strain for cutting or making showy display. Per doz. 50c; $\$ 3.50$ per 100.

PALMER'S SUPERB MIXTURE-As its name implies this mixture comprises varieties of special merit that will please the most critical grower either for cutting or bedding. Doz. 75e; per 100, $\$ 1.00$.

PALMER'S SPECIAL MITUUE-TVe offer this carefully blended mixture with the assurance that it will give the utmost satisfaction. Doz. 50c; per 100, \$3.00. single Bulbs of the above, 10c each, prepaid.

\section{Orchid Flowering Cannas}

These magnificent Summer Flowering plants ranging in height from 3 to 6 feet are most effective when planted on the lawn in groups, circular beds, or along the border.

CITY OF PORTLAND-31/2 feet. Large flowers, glowing shade of pink.

EUREKA-Beautiful large white.

MRS. ALF. CONRAD- 1 feet. Salmon pink; flowers large size GLAD DFLORA-3\% feet. Crimson, changing to carmine rose edged gold, green foliage.

CANDELABR.A-Three to five branches on each stalk. Orange, scarlet.

GOLDEN GATE-Flowers pure gold rirhly raved with orange. crimson and apricot.

IIVG IIMBERT-4 feet. Bronze foliage. Flowers very large with broad, rounded petals. A glowing orange scarlet streaked with rerimson.

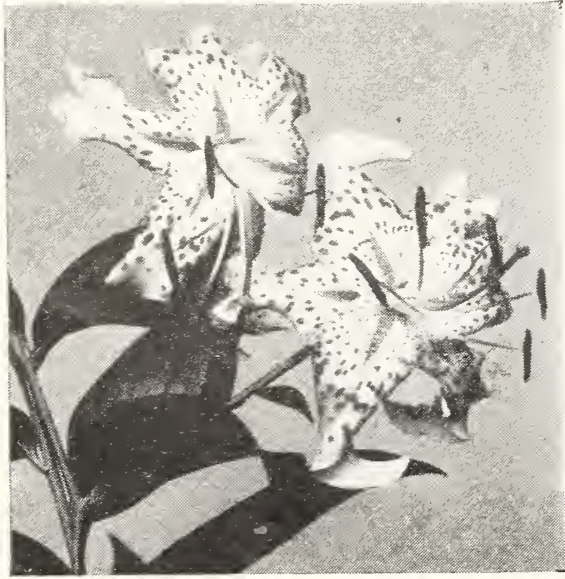

Lily Speciosum

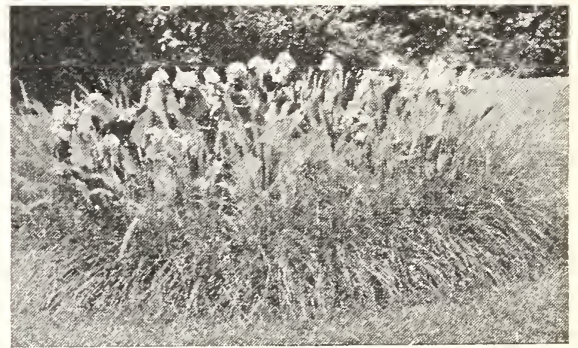

Cammas

WHE IRENIDENT-4 feet. Rich, glowing scarlet; immense, firm flowers.

WITTER's coLossAL-Largest flowered, of vivid scarlet.

YELLOW KING HC IBERT-4 feet. Green foliage. Large flowers of deap, rich vellow softly blotched with bright red.

WABAsH-Bronze leaved. Pink.

Auy of the above choice sorts $20 \mathrm{c}$ each; per dozen $\$ 2.00$, postpaid. lioots will be ready in March and April.

\section{Japanese Lilies}

(HARDY)

Magnificent giant flowering Lilies blooming in July and August. Delightfully fragrant.

LILICM SPECIOSUM ROSEUM-Rosy, white with crimson spots. LILICI SPECIOSUM ALBUM-White with greenish band thru the petals.

LILIIM AURATUM-(The Golden-Banded Lily of Japan), - Large frapre white flowers, with chocolate crimson spots and golden yellow band through center of petals. One of the finest.

Iny of the above 35c each: $\$ 4,00$ per doz. Postpaid. 


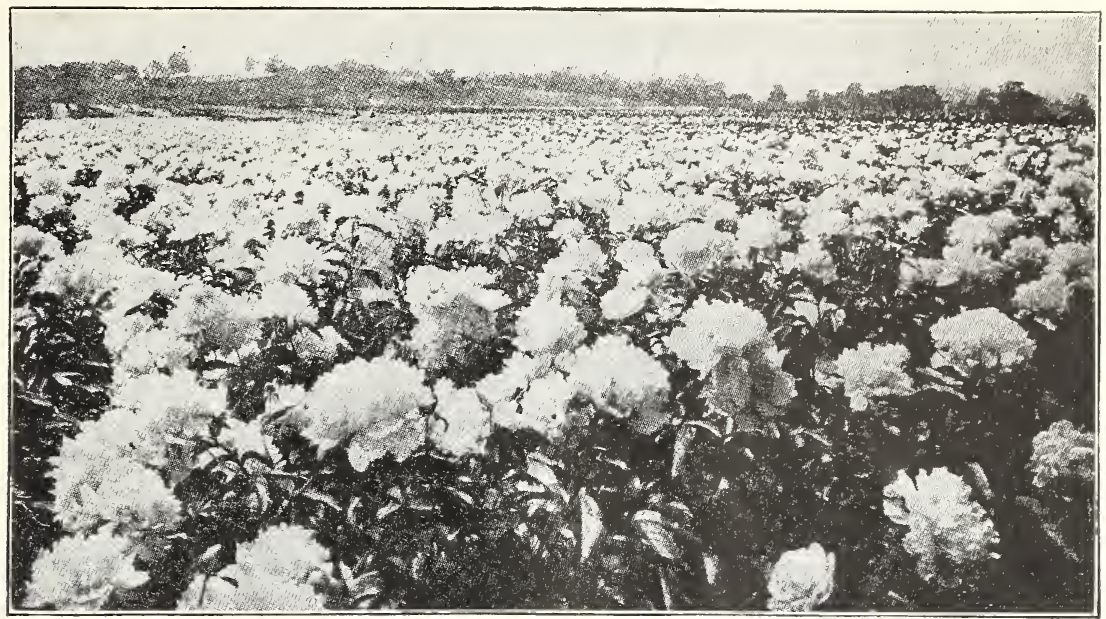

Field of Peonies

\section{Palmer's Double Peonies}

Too much praise cannot be bestowed upon these "Queen of Spring Flowers" which provide so much pleasure early in June when their beautiful huge blooms are so much admired and appreciated. The popularity of this old garden favorite is attested by the remarkable increase in production in the last decade.

We offer some of the most popular varieties as follows:

\begin{tabular}{|c|c|c|}
\hline 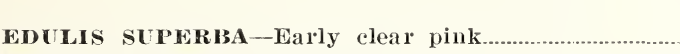 & Price, Fach Postpaid & $\begin{array}{r}\text { Dozeri } \\
\$ 5.00\end{array}$ \\
\hline MADAM CALOT Hydrangea-Pink with sulphur ti & $\ldots \ldots$ & 5.00 \\
\hline HARLEMAGNE-Lilac white, salmon pink c & .50 & 5.00 \\
\hline OUIS VAN HOUTTE-Rich deep c & .50 & 5.00 \\
\hline CROUSSE-Daz & .85 & 9.50 \\
\hline
\end{tabular}

Add 25e to dozen rate if sent by Parcel Post.

\section{Tuberoses}

DOUBLE PEARL, SELECTED BULBS-Delightfully sweet scent-

ed white flowers, Plant early in May. Each 10c; \$1.00 per doz:

Postpaid. \$7.50 per 100. Postpaid.

\section{MADEIRA OR MEXICAN VINE}

Fraglant white flowers with clean glossy green foliage and free from insects. Each, 10c; $\$ 1.00$ per dozen. Postpaid

\section{Caladium, or Elephant's Ear}

Excellent to give your lawn a tropical effect with their wide spreading leaves. Plant early, give them rich soil and a generous supply of water.

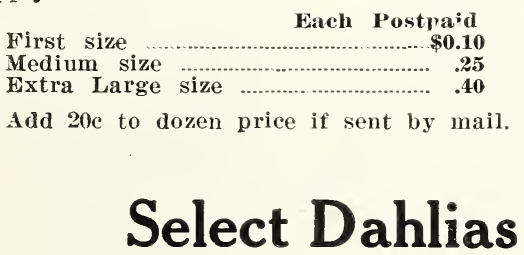

We offer a large assortment of selected field wrowl loots of the different classes under the following separate colors:

Red-Pink-White-Yellow. 25e each; \$2.50 per doz. Postpaid.

Upon request we shall be glad to quote you on any specific named varieties that you may desire.
CINNAMON VINE

Hardy, white, sweet scented climber with cimnamon-like odor attaining 15 to 25 feet when established. Each 10c; doz. \$1.00

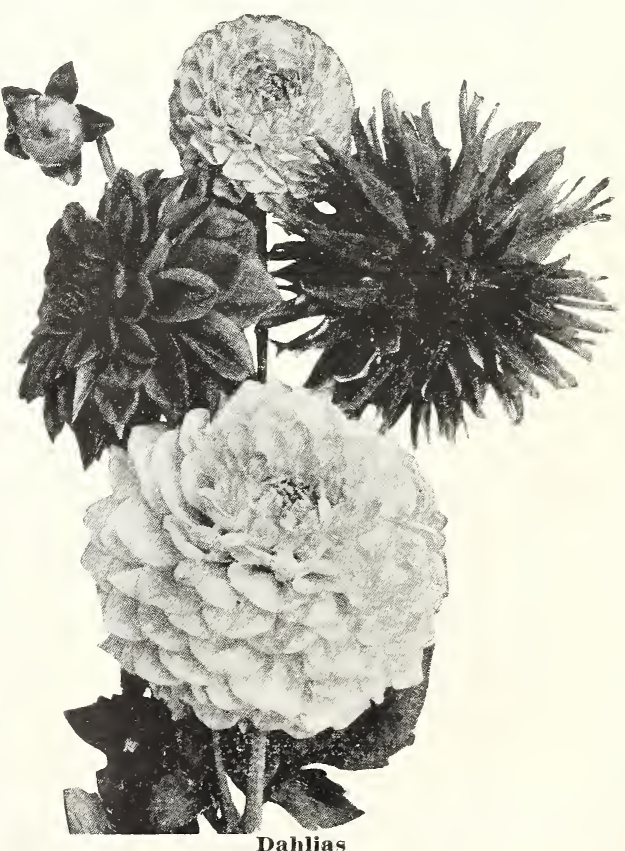




\section{Super-Plants and Bulbs}

Our growers supply us with strong, healthy plants that will start thriving immediately when you set them out. Taking the quality into consideration you will find our prices on all plants very noderate.

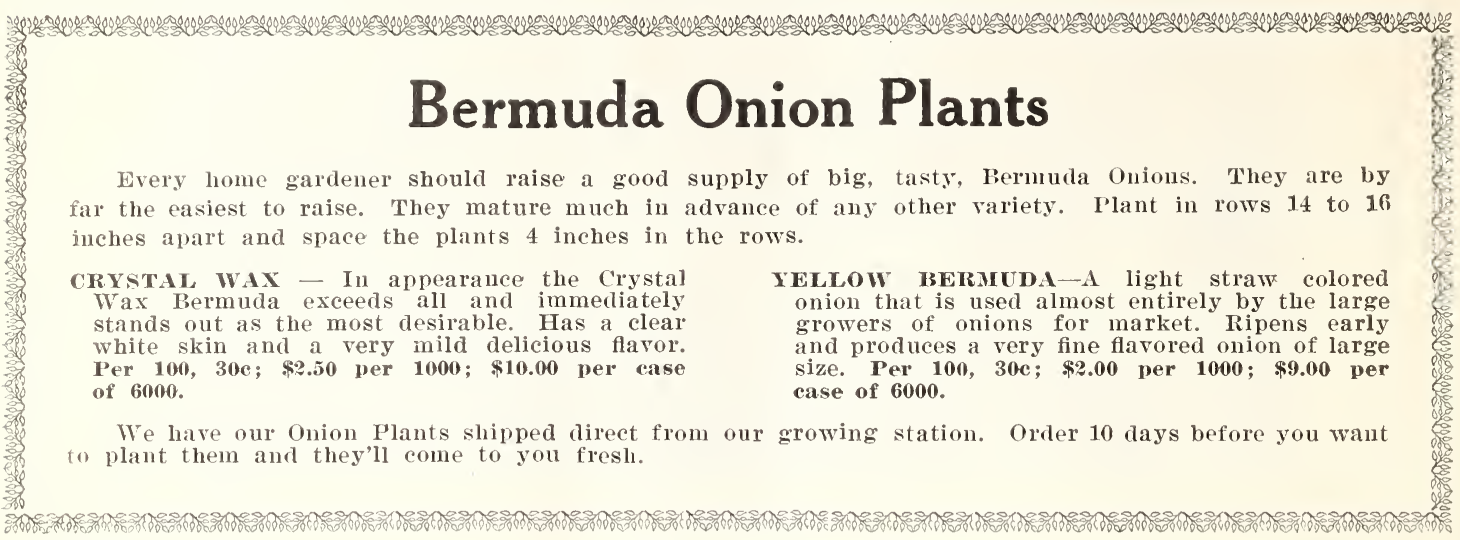

SWEET POTITO PLINTS

Red, Yellow and White (Ready in May)
CABBIGE PLINTS

\begin{tabular}{|c|c|c|c|}
\hline & 25 & 100 & 1000 \\
\hline ropenlagen & $25 c$ & $75 \mathrm{c}$ & $\$ 6.50$ \\
\hline Wakefield.. & $.25 \mathrm{c}$ & $75 \mathrm{e}$ & 6.50 \\
\hline All Season & $.25 \mathrm{c}$ & $75 c$ & 6.50 \\
\hline
\end{tabular}

CAULIFLOWER PLANTS

Early Iowar Erfurt. Doz. 15e; 1 doz. 50e; 8 doz. \$1.03

KOHLR.IBI PLINTS

25, 15e: 50, t5e; 100, 80e.

TOMATO PIANTS

$\begin{array}{rlr}12 & 4 \mathrm{Dz} & 8 \mathrm{Dz} \\ 20 \mathrm{c} & 75 \mathrm{c} & \$ 1.30 \\ 20 \mathrm{c} & 75 \mathrm{c} & 1.30 \\ 20 \mathrm{c} & 75 \mathrm{c} & 1.30 \\ 20 \mathrm{c} & 75 \mathrm{c} & 1.30\end{array}$

PEPIER PLANTS

I'oncterosia

New Stone

Globe

Reauty
100, 750: $1000, \$ 6.00$

\section{Roots}

\section{ISPIRIGIS ROOTS}

Strong two-yeatr-old roots.........................\$1.25 per 100 lbs. Giant Washington Rust l'roof, o0, \$1.00; 100, \$1.75; 1000, $\$ 16.00$.

I'almetto

50, 98c; 100, \$1.00; 1000, \$10.00

\section{HORSERADISH ROOTS}

$\$ 1.09$ ner 100 llos.

Oul special variety of horseradish roots will produce guod horseradish for use in one season's growth.

\section{RHUHARIS ROOTS}

Fach, 15e; per dozen, \$1.60.

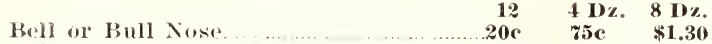

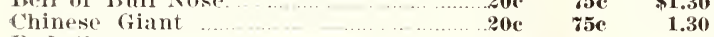
Red cayenne sereral years. 


\section{Insecticides-Fungicides}
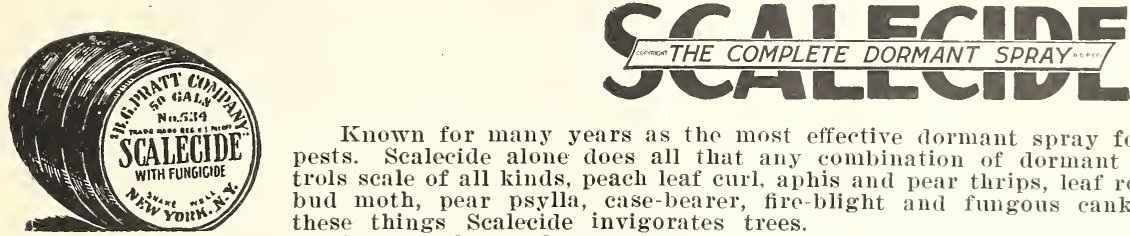

Known for many years as the most effective dormant spray for seale and many other pests. Scalecide alone does all that any combination of dormant sprays can do. It controls scale of all kinds, peach leaf curl, aphis and pear thrips, leaf roller, Furopean red mite bud moth, pear psylla, case-bearer, firc-blight and fungous cankers. In addition to all these things Scalecide invigorates trees.

Spray only on days when the temperature is above 40 degrees. Scalecide is pleasant to use-it does not injure even the eyes.

1 Quart Cans

Price

1 Gallon Cans, wt. 10 lbs.

$\$$......75

15 Gallon Drum

Price

5 Gallon Cans, wt. 50 lbs.

1.75 30 Gallon Bbl., wt. 270 lbs.

$\$ 13.50$

2 Five Gallon Cans, wt. 100 lbs

10.60

50 Gallon Bbl., wt. 450 lbs.

26.00

1 gallon makes 15 gallons of spray Seud for literation

\section{SULOCIDE}

SULFOCIDE-A highly concentrated, non-poisonous, liquid sulfur fungicide. Can be used on both peaches and apples and all kinds of fruits, vegetables and flowers. Within a few minutes after the spray is applied, it is broken down by the action of the air and the sulphur is deposited in the finest and most active fungicidal form. It gives the leaves a rich green color and imparts a beautiful lustre to the fruit 1 t. 70c; qt. $\$ 1.00$; gallon $\$ 2.75$. Use 1 qt. to 50 gallons of water.

HAMMOND'S SLUG SHOT-Non-poisonous; no danger to the person using it. It does not render vegetables or fruits on which it is applied injurious and is the best insect destroyer ever offered for the destruction of potato bugs, worms and all insects that chew. Price-5 lbs. 70c; 10 lbs. \$1.10; 50 lbs. \$5.50; 100 lbs. $\$ 10.00$. Cartons containing $1 \mathrm{lb}$. Slug Shot, 25e postpaid.

APHIS PUNK-Specially prepared for greenhouses and conservatories. It vaporizes the nicotine economically and evenly. Nothing keeps a house free from Aphis, Thrip and other plant parasites so thoroughly anc cheaply. Dozen shoets in air tight package, \$1.00.
ARSENATE OF LEAD-A powder arsenic poison used to destroy leaf-eating insects that destroy foliage on shade trees, and similar insects that feed on the fol iage of fruit trees, shade trees, vegetables, flowers and shrubbery. Mix 1 lb. to 50 gallons, fowers Half $1 \mathrm{~b} .30 \mathrm{c} ; 1 \mathrm{~b}, 50 \mathrm{c} ; 4 \mathrm{lbs}, \$ 1.60$.

BORDEAUX MITURE POWDER-A reliable fungicide. Especially recommended to control potato blight and fungus diseases affecting grapes. When used in water, for most purposes, use 6 pounds to 50 gallons of water. One gallon makes 16 to 20 gallons of spray. Send for circular, if interested. Half lb. 20c; Ib. $35 \mathrm{c} ; 4$ lbs. $\$ 1.50$.

LIME AND SULPHUR SOLUTION-An up-to-date remedy for San Jose Scale and bark lice infecting fruit and shade trees. A superior fungicide and insecticide for summer use. Dilute 1 part of lime sulphur to 40 parts water. Quart 50c; 1/2 gallon 75e; gallon $\$ 1.00 ; 5$ gallons $\$ 4.00$.

BLACK LEAF “40" (Sulphate of Nicotine) for spraying. An economical and powerful extract to kill insects. Soluble in water. One oz. bottle 35c; $1 / 2$ 1b. tin $\$ 1.00$.

NIKOTEEN (for spraying). An economical and powerful nicotine extract. One part to 600 of water to kill all insects. By express, not prepaid. Small bottles, $25 \mathrm{c} ; 1 / 21 \mathrm{z}$. bottle $\$ 1.25$.

TOBACCO DUST (fine). For green and black aphis, fleas, and beetles. Also a splendid fertilizer and preventive for insects in the ground and around roots Per 1b. 10c: 5 lbs. 40c: 100 lbs. \$4.50.

\section{Semesan Jr. Semesan Bel}

\section{The Premier Seed Disinfectants}

\section{Control Diseases, Increase Yields, Improve Quality}

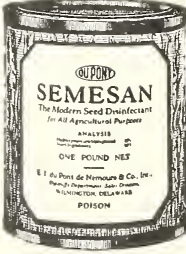

SEMESAN-The modern disinfectant can be applied in either liquid or convenient dust form to prevent or control effectively a most diversified variety of parasitic diseases and fungoid growths borne by seeds, seed pieces, plants, grafts and soils. Semesan is harmless to seed and plant life but extremely poisonous to disease and fungous but extremely poisonous to disease and fungous organisms. It generally also hastens germination, produces sturdier plants, promotes earlier maturity and increases both the quantity and quality of crop yields.

SEMESAN JR.-A less expensive but equally effective form of Semesan for the dry dust disin-

\section{PRICES FOR DU PONT SEMESAN}

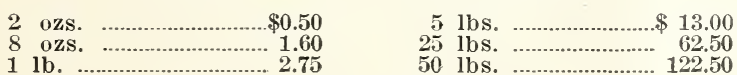

Free Descriptive Booklets Sent Upon Request

fection of both field and sweet corn seeds against the ear, root and stalk rots. Under Government conducted field tests, Semesan Jr. successfully prevented or controlled these diseases and at the 作 eased seeds by 10 to over 40 per cent.

SEMESAN BEL-Applied to whole or cut seed potatoes, either as a dry powder or a whitewash-like water mixture, Semesan Bel will prevent or control the common seed-borne potato diseases. In widely separated potato-growing sections it has caused quick sprouting, earlier maturity and greater yields.

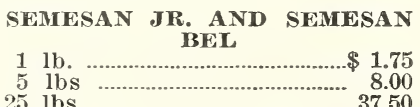

\section{Semesan Disinfectants Make Good Seeds Grow Better}




\section{Sprayers that Pay Dividends}

Judicious spraying of orchards and gardens is one of the best investments of time and money a gardener can make. By controlling and destroying insects and diseases of trees and plants you are rewarded with a greater yield of better quality fruit and vegetables. Every good gardener knows the value of regular spraying. We have to offer a few selected lines that have proved their worth.

\section{Deming's Success Bucket Sprayer}

Equipped with $4 \mathrm{ft}$. 3-8 inch hose and Bordeaux Nozzle. This is one of the best known and most serviceable bucket pumps on the market and can be used for many purposes. Price, \$7.00.

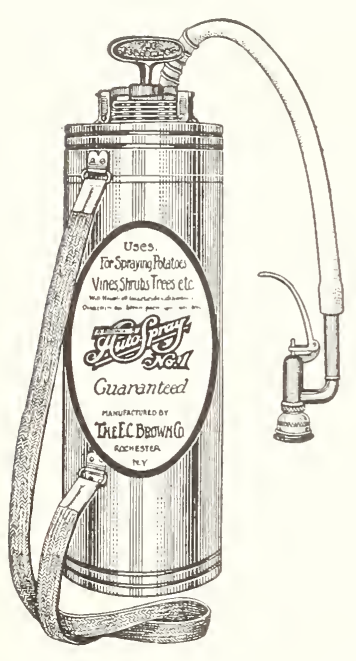

\section{Standard Spray Pump}

Showing the Standard Pump attached to barrel with 30 feet of hose, enabling the operator to walk around without moving the barrel, covering the entire tree FROM THE GROUND without the use of elevated platforms, etc. An ideal orehard sprayer at small cost.

Standard Pump, complete with two nozzles and three feet of hose. Price, \$4.50.

\section{The Faultless Insect Exterminator}

Galvanized Sprayer, 60c each. Brass Sprayer, $\$ 1.00$ each.

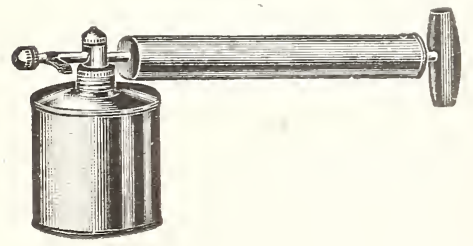

\section{G. V. Sprayers}

Due to its wide range of usefulness this all-purpose sprayer is becoming more in demand each year. Just like a garden hose, it throws a variable stream of liquid from a steady stream to a light mist with stopping operation. Successfully sprays water, insecticides, paint, varnish and all kinds of powders. "A dozen sprayers in one" as one user has chosen to term it. Can also be used as a blow torch.

No. 1, Tin, $\$ 1.25$; No. 2, Brass, $\$ 1.65$; No. 3 , an intermittent tin sprayer for 50c. 


\section{Planet Jr. GardenTools}

\section{NO. 4 PLANET JR. COMBINED HILL AND DRILL SEEDER, WHEEL HOE, CULTIVATOR AND PLOW.}

This tool combines, in a single convenient implement, a capital hill-dropping seeder, a continuous row seeder, an admirable single wheel hoe, an excellent furrower, a capital wheel cultivator and a rapid and efficient whees garden plow. In a word, with a great variety of tools garden plow. In a word, with a great variety of tools, for easy adjustment, lightness, strength and beauty. It is a practical, every-day time, labor and money saver. Holds $21 / 2$ quarts of seed.

Weight, 49 pounds.

Price, complete $\$ 18.00$ As a seeder only

14.25

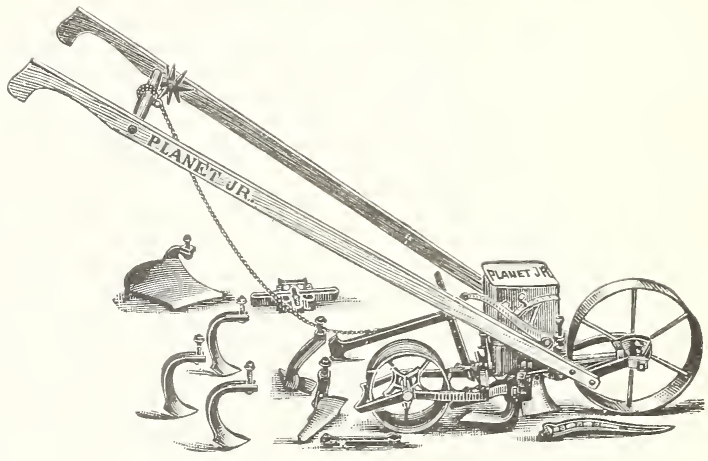

\section{NO. 3. PLANET JR: HILL AND DRILL SEEDER}

A favorite among onion growers, market gardeners and seedsmen.

The hill dropping is simple and reliable, making hills either 4, 6, 8, 12 or $2 t$ inches apart.

Change of distance between hills may be made in less than a minute by substituting one guage wheel for another.

Has 15-inch steel driving wheel. Holds 3 quarts of seed. Weight, packed, 44 lbs. Price

$\$ 17.50$

\section{NO. 12 DOUBLE WHEEL HOE, CULTIVATOR AND PLOW}

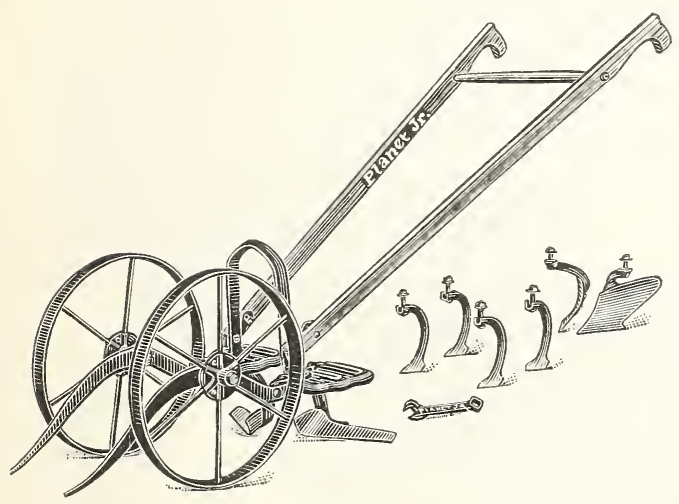

NO. 13 DOUBLE WHEEL HOE

This tool has 6 -inch hoes only, these being the tools that are most generally useful.

The hoes are the most valuable of all the wheel hoe attachments; are oil tempered and polished.

Price $\$ 8.00$ Weight, 27 lbs.

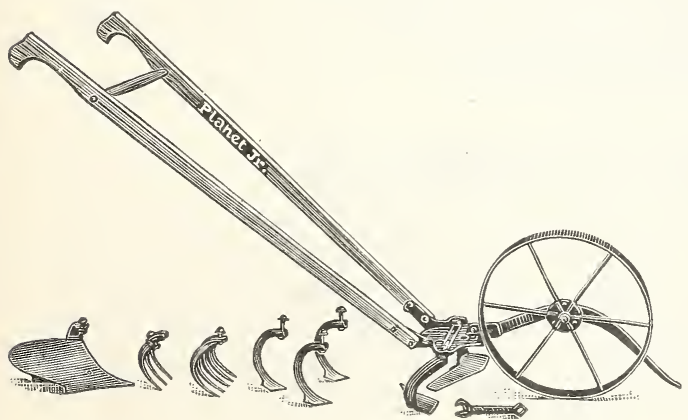

The Planet $\mathrm{Jr}$. Double Wheel Hoes are the greatest cultivating tools in the world for the onion grower, and also garden crops from drilled seed. They do more and do it better and easier than can be dome in any other way. The frame is steel.

The plows are invaluable; use them with points together for opening furrows for manure, seeds, etc., then exchange sides for covering. Use them also for plowing away from or toward the crop, both sides at once.

The cultivating teeth for deep or shallow work, and for marking out

Leaf lifters enable fine work to be done when plants are large or leaves are flat on the ground.

Price ..................................\$10.75

Weight, 33 lbs.

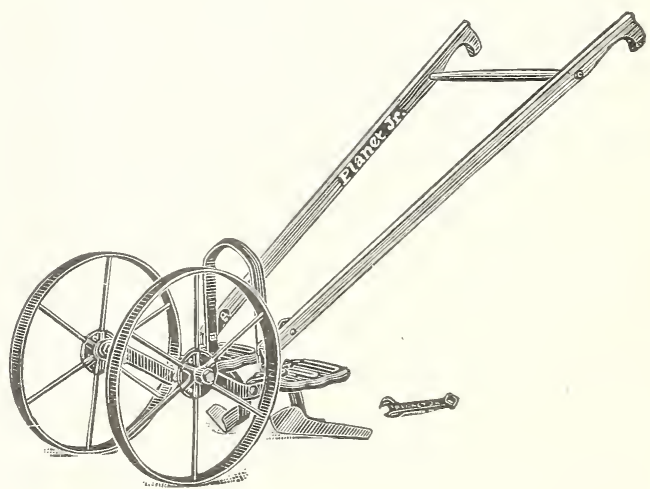

NO. 16 PLANET JR. SINGLE WHEEL HOE, CULTIVATOR, RAKE AND PLOW

This cultivator has a great variety of tools which adapt the implements to a large variety of work, and there is scarcely any garden culture of which they are not capable.

The handles are adjustable in height. The frame is steel, convenient and strong, with quick change device by which to exchange the tools.

Price 


\section{Build Up Your Soil This Year}

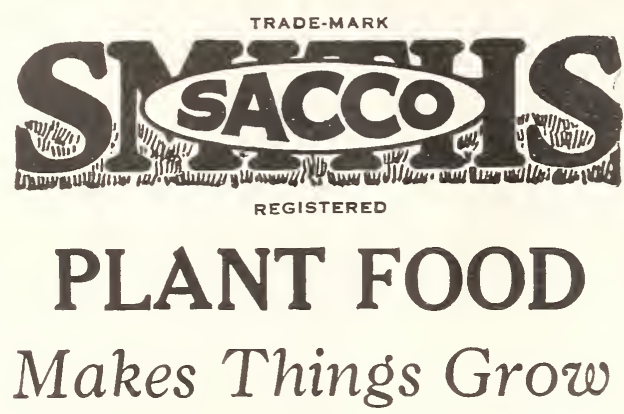

SACCO is a specially prepared PLANT FOOD for the development of fine LAWNS, GARDENS, SHRUBS, FLOWERS and TREES. It lias the endorsement of highest authorities on plant nutrition.

SACCO is rery effective and economical. A light application once or twice a year, of 2 to $t$ pounds per hundred square feet, will keep the lawn in excellent growing condition.

SACCO has four times as much plant food value as pulverized manure. Full directions for use on each package.

\section{Clean--Odorless--Easy to Apply}

\begin{tabular}{|c|c|}
\hline $\begin{array}{l}1 \mathrm{lb} . \text { Can } \\
5 \mathrm{lb} . \text { Bag }\end{array}$ & 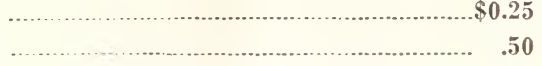 \\
\hline 10 lb. Bag & .85 \\
\hline $25 \mathrm{lb} . \mathrm{Bag}$ & 1.75 \\
\hline b. Bag & .... 3.00 \\
\hline . Bag & .... 5.00 \\
\hline
\end{tabular}

THE

PLANT FOOD

without an

EQUAL：

\section{Prepared Fertilizers}

The human race could not be expected to live long without food; we must constantly nourish our bodies to keep in existence. How many people fail to realize that plant life needs food, also? They plant their gardens year after year, diminishing the fertility of the soil each time, but never put back plant food into the soil. As a result they do not get full rewards for their work because the soil does not produce as good crops. Use a liberal application of fertilizer this spring. You will have better suceess with your gardening.

\section{PULVERIZED SHEEP MANURE}

This makes an efficient top dressing for lawns, requiring about $100 \mathrm{lbs}$. to 1000 square feet. Promotes increased rigor and productivity in garden and field crops when applied at the rate of 1 to 2 tons per acre. Price-5 lbs 30c; 10 lbs. 50c; 25 lbs. $\$ 1.00 ; 50$ lbs. $\$ 1.75 ; 100$ lbs. $\$ 3.00$.

\section{HYDRATED LIME}

Sweetens the soil and corrects acidity, making plant food elements more available. Price-10 lbs. $45 \mathrm{c} ; 50$ lbs. $\$ 1.00$.

\section{NITRATE OF SODA}

A soluble nitrogen fertilizer well known for its crop increasing results. (By express or freight only; cannot be mailed.) Price-lb. 15c; 10 lbs. \$1.10; 50 lbs. $\$ 3.50$.

\section{BONE MEAL}

An excellent top dressing for all uses. Especially suitable for gardens and around fruit trees and shrubs. Use 400 to $500 \mathrm{lbs}$. per aere. Analysis 11/4. 29-0. Price- -10 lbs. 60c; 25 lbs. $\$ 1.50 ; 50$ lbs. $\$ 2.25$; 125 lb. sacks $\$ 4.75$.

\section{Concentrated Fertilizers}

\section{STIMUPLANT}

Tablet form fertilizer for house plants, garden crops and flower beds. Rich in concentrated plant food, clean, odorless and convenient to use. PriceBox of 30 tablets, 25c.

\section{FLORANID UREA}

Contains 46 per cent nitrogen. A high grade organic plant food for vegetables, flowers, shrubs, and lawns. Pleasant to use and produces remarkable results. Price-Half 1 b. can $50 \mathrm{c}$; lb. can $75 \mathrm{c}$; 50 lbs. for $\$ 11.00$. 


\section{The Latest Sensation in Tomato Improvement!}

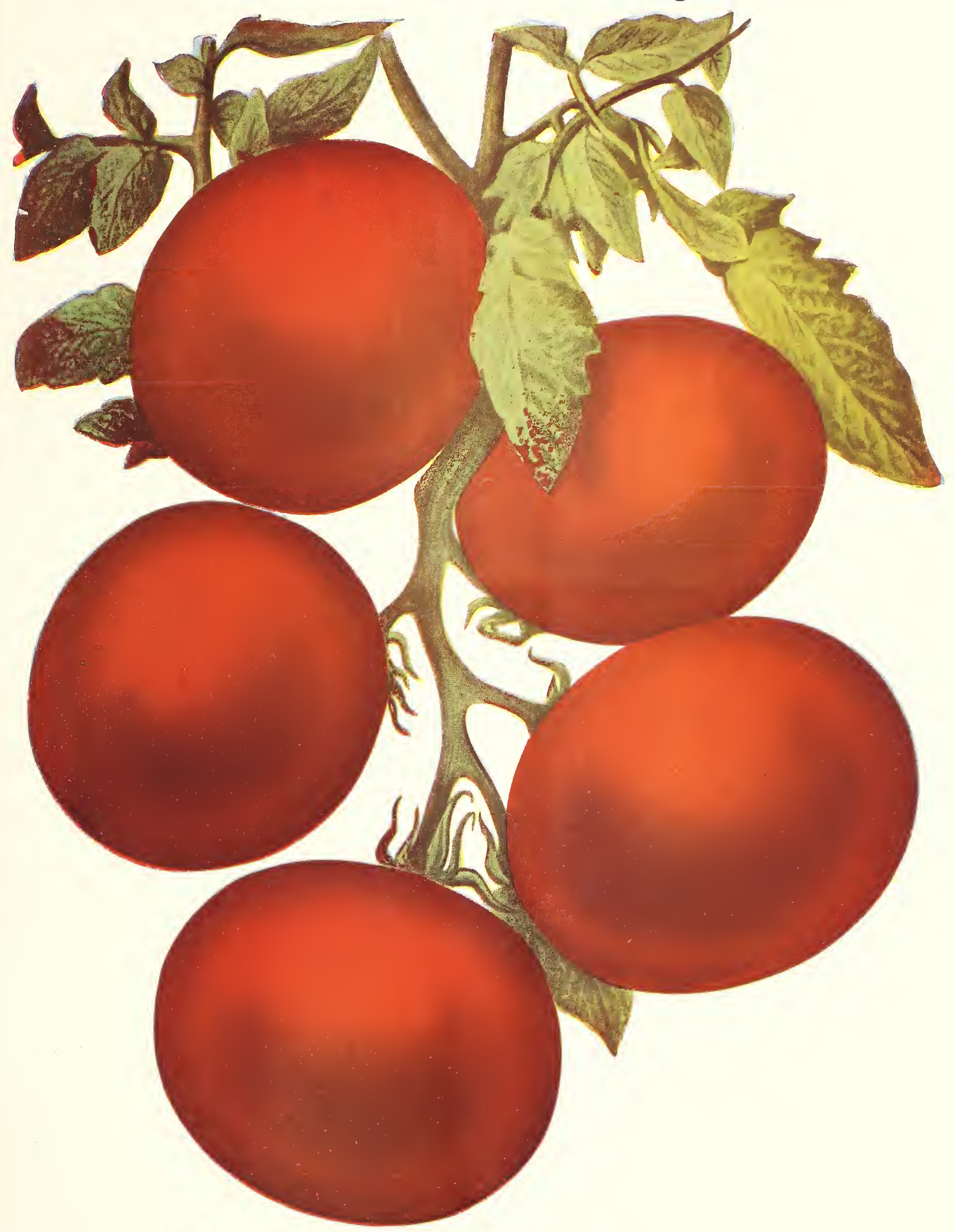

\section{Marglobe Tomato (Wilt Resistant)}

A new early tomato with strong, vigorous vines producing beautifully shaped scarlet fruit. Will successfully withstand long periods of unfavorable weather, and is praised everywhere for its ability to resist Nailhead Rust and Fusarium Wilt. It is making a big hit with canners-one crop last year yielded 21 tons per acre. Give Marglobe a prominent place in your garden this year. Packet $25 \mathrm{c} ; 1 \mathrm{oz} . \$ 1.00 ; 1 / 4$ lb. $\$ 3.50 ; 1$ lb. $\$ 13.00$. 


\section{Palmer's Super Quality LAWN GRASS SEED}

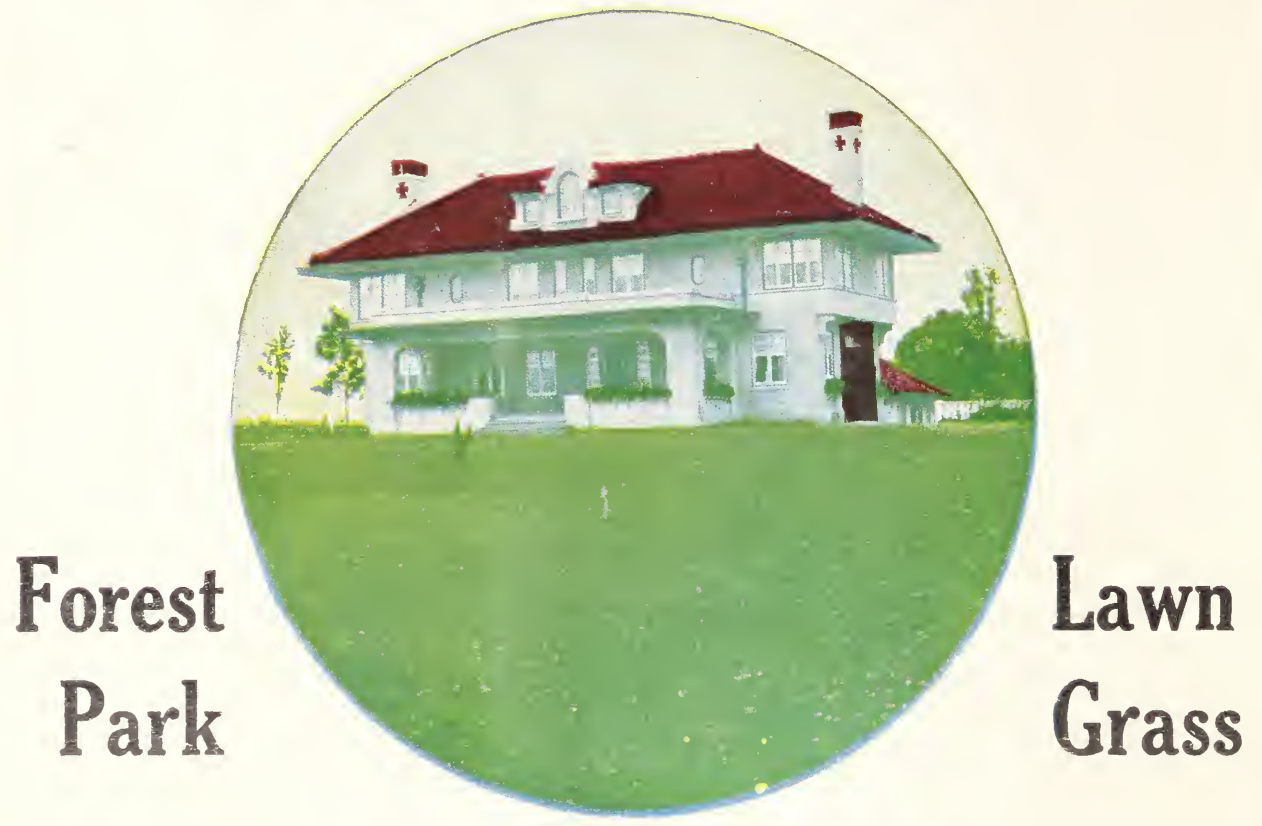

Because of their original inheritance of vigor and beauty from carefully supervised fields, followed by the latest improved refining process, SUPER-QUALITY grass seeds represent the finest that nature produces. They are carefully selected and the quality is verified by careful tests before they are placed on the market.

We cater extensively to a critical trade, including many prominent golf courses, parks, estates and institutions. However, you will find our prices on the average not higher than you pay for the ordinary grades.

Kentuck Blue GRAs (Poa Pratensis). The most popular and reliable of all domestic grass seeds. Produces a rich. green turf of firm structure which thrives easily under good care.

CANADIAN BLUE GRASs (Poa Compressa). Similar to Kentucky Blue Grass but of lighter green color and better adapted to poor, thin soils.

RED TOP GRASS (Agrostis Alba). An excellent fine leaved grass for quick growth. Used extensively in fairway mixtures on golf courses.

ENGLISH RYE GRASs (Lolium Perenne). A quick growing perennial grass, rather wide blades but rery desimble in lawn nixtures for quick results.

CREEPING BENT (Agrostis Stolonifera). By far the most beautiful of all turf grasses. It makes a low relvet like growth of rich green. Par-

ticularly desirable for putting greens and fine lawns.

RED CREEPING FESCUE (Festuca Rubra). A very fine grass producing an abundance of closely formed turf which makes an excellent lawn, flourishes well on sandy soils, but favorably adapted to the average soil as well.

ROCGH STALKED MEADOW GRASS (Poa Trivialis.) Grows from one and one-half to two feet high, has a perennial creeping root and an erect, slender, smooth stem. W W ell adapted to shaded situations, such as orchards and parks. Sow about thirty pounds per acre. Lb. $\$ 1.00 ;$ bu. (15 lbs.) \$12.00.

WHITE DUTCH CLOVER (Trifolium repens). This old reliable lawn grass needs no introduction as it is found everywhere.

\section{Forest Park Lawn Grass}

A SPECIAL FORMULA FOR OPEN OR SHADY PLACES.

This wonderful mixture is a blend of the most desirable imported and domestic grasses, each of which has its season of beauty. The result of this blending is the producing of a turf which is always green and velvety, insuring a beautiful lawn from early spring until late fall. Many of the finest lawns in our city are seeded with FOREST PARK LAWN GRASS. Inasmuch as a well blended mix. ture is to be preferred against a single variety of grass we recommend FOREST PARK LAWN GRASS to you as the best that can be produced. It is as free from impurities and weeds as expert knowledge and modern refining machinery can make it. Try it on your lawn this spring and we are sure you will use it always. If you pay twice as much you could not get better.

\section{Prices on Lawn Grass Seed}

Lb. 3 Ibs. 5 Ibs. 10 lbs.

Kentucky Blue Grass..

Canadian Blue Grass....

English Rye Grass........ $\quad .25 \quad .70 \quad 1.10 \quad 2.00$

Red Top.

$\begin{array}{rrr}.70 & 1.10 & 2.00 \\ 1.40 & 2.25 & 4.25\end{array}$

Red Creeping Fescue.... South German Creeping Bent

White Dutch Clover...... .75

Meadow Grass

300 square feet.
Lb. 3 lbs. 5 lbs. 101 bs.

$\begin{array}{llll}.60 & 1.75 & 2.75 & 5.50\end{array}$

$\begin{array}{lll}3.50 & 5.50 & 11.00\end{array}$

$2.00 \quad 3.25$

$2.00 \quad 3.25$ 